\title{
DIAGNÓSTICO DA TUBERCULOSE NA POPULAÇÃO CARCERÁRIA DOS DISTRITOS POLICIAIS DA ZONA OESTE DA CIDADE DE SÃO PAULO
}

\author{
REGINA MAURA CABRAL DE MELO ABRAHÃO
}

Tese de Doutorado apresentada ao Departamento de Epidemiologia da Faculdade de Saúde Pública da Universidade de São Paulo para obtenção do Título de Doutor em Saúde Pública.

Área de concentração:

Epidemiologia

\author{
ORIENTADOR: PROFESSOR ASSOCIADO \\ PÉRICLES ALVES NOGUEIRA
}

São Paulo 
"Não se contente em trilhar um caminho estabelecido.

Ao contrário, vá para onde não há caminho algum e deixe seu rastro". 
Ao Sergio

Metade que se arrancou

O chão que desabou

A luz que se apagou

$\mathrm{O}$ amor que eternizou

À Isadora

O presente que ficou

$\mathrm{O}$ amor que me curou

À minha família e amigas

Pela dor compartilhada

Pela saúde recuperada

Ao Dr. Péricles

Pela amizade consolidada

Por essa vitória alcançada 


\section{AGRADECIMENTOS}

À todos que, direta ou indiretamente, contribuíram para a realização deste trabalho.

Ao Prof. Associado Dr. Péricles Alves Nogueira, pela amizade, pela participação e incentivo em todos os momentos do trabalho e pela orientação recebida.

À Dra. Maria Ivette Carboni Malucelli, pela co-orientação, pela participação nesta pesquisa, pela grande amizade e principalmente pela presença constante em todos os momentos marcantes de minha vida.

Ao Delegado de Polícia Titular da $3^{a}$ Delegacia Seccional de Polícia - Oeste, Dr. Fernão de Oliveira Santos, pela viabilização desta pesquisa, e especialmente pela extrema gentileza, amizade e apoio incondicional durante e após o trabalho realizado.

Aos Investigadores da Polícia Civil Vicente Plumeri Neto, Nelson Antônio de Lima Júnior e Vicente Conti, pela proteção policial, amizade e disponibilidade para nos acompanhar em todos os Distritos Policiais.

Aos Delegados, Investigadores da Polícia Civil e funcionários dos Distritos Policiais da Zona Oeste da Cidade de São Paulo, pelo apoio recebido.

À Dra. Vera Maria Neder Galesi, Dra. Laedi Alves Rodrigues dos Santos e Enfermeira Cláudia Valência Montero, da Divisão de Tuberculose do Centro de Vigilância Epidemiológica "Prof. Alexandre Vranjac", da Secretaria de Estado da Saúde, pelas informações atualizadas sobre tuberculose, pela amizade, e pelo fornecimento de frascos de PPD, de meios de cultura e material de laboratório, permitindo a realização desta pesquisa.

Às amigas Maria Alice, Sueli, Maria Conceição e Lucilaine, do Setor de Micobactérias do Instituto Adolfo Lutz de São Paulo, pela realização do Teste de Identificação das cepas isoladas nos escarros dos detentos e do Teste de Sensibilidade às drogas antituberculose, fundamentais para a conclusão deste trabalho. À vocês, meu eterno agradecimento. 
À Enfermeira Cleuza Nogueira de Souza Pereira, da antiga ARS-8 e hoje Coordenadoria de Saúde de Perus, pela aplicação e leitura do teste tuberculínico. Aos Auxiliares de Enfermagem Claudemir, Maria Celestina, Maria Aparecida e Sueli, pela cooperação durante o inquérito individual aplicado nos detentos dos Distritos Policiais daquela região.

À Enfermeira Elza da Coordenadoria de Saúde de Campo Limpo (antiga ARS-10); pela aplicação e leitura do teste tuberculínico. A todos os Auxiliares de Enfermagem, que cooperaram durante o inquérito individual aplicado nos detentos dos Distritos Policiais da região.

Às Enfermeiras Maria das Graças Lira Oliveira e Dra. Hogla Cardozo Murai, da antiga ARS-2, hoje Coordenadoria de Saúde de Pinheiros, pela aplicação e leitura do teste tuberculínico. Às Auxiliares de Enfermagem que participaram da aplicação do inquérito individual nos detentos dos Distritos Policiais da região.

Um agradecimento especial à Enfermeira Dra. Hogla Cardozo Murai, pela amizade, disponibilidade em realizar o teste tuberculínico em Distritos Policiais que não pertenciam à sua Coordenadoria de Saúde, e pela total cooperação em toda a fase do trabalho com os detentos.

Às Enfermeiras do Centro de Saúde Escola "Geraldo de Paula Souza" da USP, Luciana Xavier Junqueira e Maria de Fátima e Souza, pela amizade e aplicação e leitura do teste tuberculínico. Às Auxiliares de Enfermagem Natalina, Maria Benedita e Maria da Piedade, pela participação na aplicação do inquérito individual nos detentos.

À Prof. Associada Sabina Lea Davidson Gotlieb, do Departamento de Epidemiologia, da Faculdade de Saúde Pública da Universidade de São Paulo, pela criteriosa revisão das tabelas apresentadas nesta pesquisa.

À Prof. Dra. Denise Pimentel Bergamaschi, do Departamento de Epidemiologia, da Faculdade de Saúde Pública da Universidade de São Paulo, pela valiosa colaboração nas análises estatísticas deste trabalho. 
À todos os docentes da área de Tisiologia da Faculdade de Saúde Pública da USP.

À Ana Lúcia Emigdio Silva, funcionária do Laboratório de Micobactérias da Faculdade de Saúde Pública da USP, pela amizade, cooperação durante a coleta dos dados e auxílio na realização dos exames laboratoriais.

\begin{abstract}
À Bibliotecária da Faculdade de Saúde Pública da USP, Maria Lúcia de Faria Ferraz, pela amizade e valiosa contribuição na revisão das referências bibliográficas. Às funcionárias da Biblioteca, e especialmente à Suely de Olim Santos pela aquisição de artigos científicos em Universidades nacionais e internacionais.
\end{abstract}


Trabalho realizado com o auxílio financeiro da Fundação de Amparo à Pesquisa do Estado de São Paulo (FAPESP).

(Processo nº 00/06991-9) 


\section{RESUMO}

\section{Abrahão RMCM. Diagnóstico da tuberculose na população carcerária dos}

Distritos Policiais da Zona Oeste da Cidade de São Paulo. São Paulo; 2003. [Tese de Doutorado - Faculdade de Saúde Pública da USP].

Objetivo. A prevalência e incidência da tuberculose na população prisional é muito maior que na população geral. Conhecer a prevalência de infectados, doentes e características físicas, sociais e criminais dos presos, foram objetos deste estudo. Métodos. Realizou-se uma busca ativa de casos de tuberculose nos 1.052 detentos de 9 Distritos Policiais da Zona Oeste da Cidade de São Paulo, entre 2000-2001. Após a aplicação de um inquérito e da prova tuberculínica, foram realizados os exames de baciloscopia, cultura, identificação e teste de sensibilidade às drogas antituberculose. Resultados. Do total de 1.052 detentos 99,7\% eram homens; 71,3\% tinham entre 18 e 29 anos; $82,4 \%$ eram solteiros ou amasiados; $51,4 \%$ eram pretos ou pardos; $64,5 \%$ não completaram o $1^{\circ}$ grau; $40 \%$ praticaram o roubo como principal delito; $3,7 \%$ tiveram tuberculose no passado e 32,8\% eram sintomáticos respiratórios. Dos 932 que fizeram a prova tuberculínica, 64,5\% estavam infectados. Dos 1.017 escarros analisados, $8(0,8 \%)$ foram positivos na baciloscopia e $54(5,3 \%)$ na cultura. Das 54 cepas isoladas, 38,9\% eram $M$. tuberculosis e 61,1\% eram micobactérias não tuberculosas. Das 21 cepas de M. tuberculosis, 85,7\% eram sensíveis, 9,5\% eram resistentes à isoniazida e rifampicina e $4,8 \%$ à isoniazida, rifampicina e pirazinamida. Conclusões. Pela baciloscopia, o coeficiente de prevalência de tuberculose (por 100.000 detentos) foi de 787, e pela cultura de 5.310, cerca de 30 e 203 vezes mais que o da população da cidade de São Paulo, respectivamente. O fato de haver 3 detentos com cepas multirresistentes às drogas antituberculose é uma ameaça à saúde pública.

Descritores: Tuberculose em presos; Distritos Policiais; Prova tuberculínica; Exames laboratoriais. 


\title{
SUMMARY
}

\author{
Abrahão RMCM. Tuberculosis diagnosis in inmates of the County Jails of the \\ West Section of the City of São Paulo. São Paulo; 2003. [PHD Thesis - Faculdade \\ de Saúde Pública da USP (University of São Paulo Public Health College)].
}

Purpose. The prevalence and incidence of tuberculosis in inmates population is much larger than in the general population. The purpose of this study was acquiring good knowledge of the prevalence of infected person and tuberculosis patients, as well as the physical, social and criminal characteristics of inmates. Methods. An active search of tuberculosis cases was conducted among the 1,052 inmates of 9 County Jails of the West Section of the São Paulo City between 2000-2001. After application of an inquiry and the tuberculin skin test, laboratory investigations were also conducted such as sputum bacilloscopy, culture, identification and the test of sensitivity to anti-TB drugs. Results. Out of the total number of 1,052 inmates, $99.7 \%$ were males; $71.3 \%$ were in the group of ages 18 and 29 years old; $82.4 \%$ were single or had sexual mates; $51.4 \%$ were negroes or mulattos; $64.5 \%$ had low education level; $40 \%$ had been engaged in thefts/robberies; $3.7 \%$ had tuberculosis episodes in the past and 32.8\% displayed respiratory symptoms. Out of the 932 which underwent the tuberculin skin test, $64.5 \%$ were infected. Out of the 1,017 sputum samples analyzed, $8(0.8 \%)$ had positive bacilloscopy and $54(5.3 \%)$ positive culture. Of the 54 strains isolated, $38.9 \%$ were $M$. tuberculosis and $61.1 \%$ were nontuberculosis mycobacteria. Of the $21 \mathrm{M}$. tuberculosis strains $85.7 \%$ were sensitive, 9.5\% were resistant to isoniazide and rifampicin and $4.8 \%$ to isoniazide, rifampicin and pyrazinamide. Conclusions. Based on the bacilloscopy, the tuberculosis prevalence rate (per 100,000 inmates) was 787 and based on the culture was 5,310 inmates, around 30 and 203 times higher than that of the São Paulo city population, respectively. The fact that 3 inmates had strains multi-resistant to anti-TB drugs can be deemed a threat to the public health.

Descriptors: Tuberculosis in inmates; County Jails; Tuberculin skin test; Laboratory investigations. 


\section{LISTA DE TABELAS}

Tabela 1 - Distribuição do número total e percentagem de detentos informado pelos Delegados de Polícia, em relação aos detentos examinados, nos Distritos Policiais da Zona Oeste da Cidade de São Paulo, 2000-2001.-

Tabela 2 - Distribuição do número e percentagem dos detentos, segundo a faixa etária. Distritos Policiais da Zona Oeste da Cidade de São Paulo, 2000-2001. $-48$

Tabela 3- Distribuição do número e percentagem dos detentos, segundo o estado civil e a faixa etária. Distritos Policiais da Zona Oeste da Cidade de São Paulo, 2000-2001 $-49$

Tabela 4 - Distribuição do número e percentagem dos detentos, segundo a cor ou raça. Distritos Policiais da Zona Oeste da Cidade de São Paulo, 20002001 . $-51$

Tabela 5 - Distribuição do número e percentagem dos detentos, segundo o local de nascimento. Distritos Policiais da Zona Oeste da Cidade de São Paulo, 2000-2001.

Tabela 6 - Distribuição do número e percentagem dos detentos, segundo o nível de instrução. Distritos Policiais da Zona Oeste da Cidade de São Paulo, 2000-2001.

Tabela 7 - Distribuição do número e percentagem dos detentos assalariados, segundo a renda mensal. Distritos Policiais da Zona Oeste da Cidade de São Paulo, 2000-2001 $-55$ 
Tabela 8 - Distribuição do número e percentagem dos detentos, segundo a profissão. Distritos Policiais da Zona Oeste da Cidade de São Paulo, 2000-2001. $-56$

Tabela 9 - Distribuição do número e percentagem dos detentos, segundo o local de residência. Distritos Policiais da Zona Oeste da Cidade de São Paulo, 2000-2001 $-58$

Tabela 10 - Distribuição do número e percentagem dos detentos primários e reincidentes, segundo o tempo de permanências nos Distritos Policiais da Zona Oeste da Cidade de São Paulo, 2000-2001.-------60

Tabela 11 - Distribuição do número e percentagem dos detentos primários e reincidentes, segundo o delito atual. Distritos Policiais da Zona Oeste da Cidade de São Paulo, 2000-2001 $-62$

Tabela 12 - Distribuição do número e percentagem dos detentos reincidentes, segundo o delito anterior. Distritos Policiais da Zona Oeste da Cidade de São Paulo, 2000-2001. $-66$

Tabela 13 - Distribuição do número e percentagem dos detentos que tiveram tuberculose anteriormente, segundo a faixa etária. Distritos Policiais da Zona Oeste da Cidade de São Paulo, 2000-2001. $-68$

Tabela 14 - Distribuição do número e percentagem dos detentos sintomáticos, segundo os sintomas de tuberculose. Distritos Policiais da Zona Oeste da Cidade de São Paulo, 2000-2001. $-70$

Tabela 15 - Distribuição do número e percentagem dos detentos sintomáticos, segundo o tempo de sintomas de tuberculose. Distritos Policiais da Zona Oeste da Cidade de São Paulo, 2000-2001. $-71$ 
Tabela 16 - Distribuição do número e percentagem dos detentos primários e reincidentes, segundo o resultado da prova tuberculínica. Distritos Policiais da Zona Oeste da Cidade de São Paulo, 2000-2001.--------73

Tabela 17 - Distribuição do número e percentagem dos detentos que fizeram a prova tuberculínica, segundo sintomas de tuberculose. Distritos Policiais da Zona Oeste da Cidade de São Paulo, 2000-2001. $-75$

Tabela 18 - Distribuição do número e percentagem dos detentos que fizeram a prova tuberculínica, segundo o tempo de permanência nos Distritos Policiais da Zona Oeste da Cidade de São Paulo, 2000-2001.--------76

Tabela 19 - Distribuição do número e percentagem dos detentos, segundo o resultado da baciloscopia de escarro. Distritos Policiais da Zona Oeste da Cidade de São Paulo, 2000-2001 $-81$

Tabela 20 - Distribuição do número e percentagem dos detentos, segundo o resultado da cultura de escarro. Distritos Policiais da Zona Oeste da Cidade de São Paulo, 2000-2001. $-82$

Tabela 21 - Distribuição do número e percentagem dos detentos com cultura positiva, nos Distritos Policiais da Zona Oeste da Cidade de São Paulo, 2000-2001

Tabela 22 - Distribuição do número e percentagem dos detentos, segundo os resultados da baciloscopia e cultura e sintomas de tuberculose. Distritos Policiais da Zona Oeste da Cidade de São Paulo, 20002001. 
Tabela 23 - Distribuição do número e percentagem dos detentos, segundo a identificação das cepas de micobactérias isoladas na cultura de escarro. Distritos Policiais da Zona Oeste da Cidade de São Paulo,

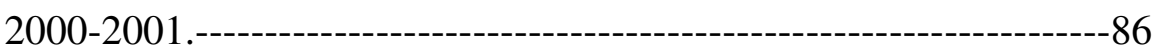

Tabela 24 - Distribuição do número e percentagem dos detentos portadores de cepas identificadas como M. tuberculosis. Distritos Policiais da Zona Oeste da Cidade de São Paulo, 2000-2001 $-87$

Tabela 25 - Distribuição do número e percentagem dos detentos portadores de cepas identificadas como micobactérias não tuberculosas (MNT). Distritos Policiais da Zona Oeste da Cidade de São Paulo, 20002001 88

Tabela 26 - Distribuição do número e percentagem dos detentos cultura-positivos e que fizeram a prova tuberculínica, segundo a identificação das cepas de micobactérias isoladas. Distritos Policiais da Zona Oeste da Cidade de São Paulo, 2000-2001

Tabela 27 - Distribuição do número e percentagem dos detentos, segundo o resultado do teste de sensibilidade às drogas antituberculose nas cepas identificadas como M. tuberculosis, isoladas na cultura de escarro. Distritos Policiais da Zona Oeste da Cidade de São Paulo, 2000-2001. 


\section{LISTA DE GRÁFICOS}

Gráfico 1 - Percentagem de detentos primários, não reatores e reatores à prova tuberculínica, segundo o tempo de permanência nos Distritos Policiais da Zona Oeste da Cidade de São Paulo, 2000-2001 $-77$

Gráfico 2 - Percentagem de detentos reincidentes, não reatores e reatores à prova tuberculínica, segundo o tempo de permanência nos Distritos Policiais da Zona Oeste da Cidade de São Paulo, 2000-2001. $-78$ 


\section{LISTA DE SIGLAS E ABREVIATURAS}

AIDS = Síndrome da Imunodeficiência Adquirida (sigla de "Acquired Immuno Deficiency Syndrome”)

BCG = Bacilo de Calmette-Guérin (vacina antituberculose)

CDC $=$ Centers for Disease Control and Prevention

CDP $=$ Centro de Detenção Provisória

CVE $=$ Centro de Vigilância Epidemiológica

DEPEN = Departamento Penitenciário Nacional

DP $=$ Distrito Policial

FEBEM = Fundação Estadual do Bem-Estar do Menor

HIV = Vírus da Imunodeficiência Humana (sigla de "Human Immunodeficiency Virus")

IBGE = Instituto Brasileiro de Geografia e Estatística

ILANUD = Instituto Latino Americano das Nações Unidas para Prevenção do Delito INH = Isoniazida

MNT = Micobactéria não tuberculosa

M. tuberculosis $=$ Mycobacterium tuberculosis

OMS = Organização Mundial da Saúde

PPD = Derivado Protéico Purificado (Sigla de "Purified Protein Derivative"), referindo-se, neste trabalho, ao PPD-RT23

PZA = Pirazinamida

RFLP = Polimorfismo de Tamanho de Fragmentos de Restrição (Sigla de "Restriction Fragment Lenght Polymorphism”)

$\mathbf{R M P}=$ Rifampicina

TB-MDR = Tuberculose Multidroga-resistente

USP $=$ Universidade de São Paulo

WHO $=$ World Health Organization 


\section{ÍNDICE}

1- INTRODUÇÃO

2- OBJETIVOS 17

2.1- Objetivo Geral 17

2.2- Objetivos Específicos 17

3- MATERIAL E MÉTODOS 18

3.1- População de Estudo 18

3.2- Caracterização dos Distritos Policiais 18

3.2.1- $\mathbf{7}^{\circ}$ Distrito Policial - Lapa 19

3.2.2- 14 ${ }^{\circ}$ Distrito Policial - Pinheiros 19

3.2.3- 33 ${ }^{\circ}$ Distrito Policial - Pirituba 20

3.2.4- 34 ${ }^{\circ}$ Distrito Policial - Morumbi 20

3.2.5- 37 ${ }^{\circ}$ Distrito Policial - Campo Limpo 20

3.2.6- 46 $^{\circ}$ Distrito Policial - Perus 21

3.2.7- 87 ${ }^{\circ}$ Distrito Policial - Pereira Barreto 21

3.2.8- 89 ${ }^{\circ}$ Distrito Policial - Portal do Morumbi 22

3.2.9- 91 ${ }^{\circ}$ Distrito Policial - Ceasa 22

3.3- Levantamento dos Dados 22

3.3.1- Elaboração da Estratégia 22

3.3.2- A estratégia 24

3.3.3- Técnicas utilizadas $\quad 25$

3.3.3.1- Inquérito individual 25

- Material necessário para a entrevista, por meio do inquérito individual 27 
- Material necessário para a aplicação e leitura da prova tuberculínica 28

3.3.3.3- Processamento das amostras de escarro 28

- Baciloscopia 28

- Cultura 29

- Material necessário para a coleta de escarro 29

3.4- Análise dos Dados 30

3.5- Análise das Variáveis 41

3.5.1- Faixa etária $\quad 42$

3.5.2- Cor ou raça 42

3.5.3- Local de residência 42

3.5.4- Tempo de permanência 43

3.5.5- Tempo de sintomas 44

3.5.6- Prova tuberculínica 44

3.5.7- Baciloscopia 44

3.5.8- Cultura 45

3.5.9- Prevalência de detentos com tuberculose 45

3.6- Processamento dos Dados 45

4- RESULTADOS E DISCUSSÃO 46

5- CONCLUSÕES 99

6- RECOMENDAÇÕES 102

6.1- Gerais 102

$\begin{array}{ll}\text { 6.2- Específicas } & 102\end{array}$

7- COMENTÁRIOS FINAIS 105 
ANEXOS

- Anexo 1- Termo de Consentimento Esclarecido

- Anexo 2- Inquérito Individual

150

- Anexo 3- Ficha de pré-codificação 


\section{1- INTRODUÇÃO}

Apesar da tuberculose ser uma das doenças mais antigas da humanidade e também uma das mais estudadas, ela continua a ser um dos grandes desafios da Saúde Pública em todos os países, principalmente naqueles em desenvolvimento. Provavelmente, esta doença atravessará as próximas décadas consumindo uma grande parte dos recursos destinados à saúde e gerando muito sofrimento e incapacidade física ${ }^{25}$.

Atualmente, a tuberculose está entre as dez principais causas de mortalidade no mundo. Cerca de $80 \%$ dos casos são encontrados em 22 países, sendo que as maiores taxas de incidência são observadas na África Subsaariana e no sudeste da Ásia ${ }^{7,26,66}$.

Segundo estimativas realizadas pela Organização Mundial da Saúde (OMS), durante a década de 1990-1999, um terço da população mundial estaria infectada pelo Mycobacterium tuberculosis e ocorreriam no mundo 88 milhões de casos novos de tuberculose, dos quais, 8 milhões seriam atribuídos à infecção pelo HIV H,20,22,60,81 $^{\text {. }}$

Estimou-se também, que o número de casos novos de tuberculose que ocorrem a cada ano no mundo, aumentaria de 7,5 milhões (143 casos por 100.000 habitantes) em 1990 para 8,8 milhões (152 casos por 100.000 habitantes) em 1995 e 10,2 milhões (163 casos por 100.000 habitantes) no ano 2000, correspondendo a um aumento de $36 \%{ }^{19,60}$. Projeções feitas em 1995 indicaram que no ano 2005 ocorrerão 11,9 milhões de casos novos de tuberculose, anualmente ${ }^{60}$. Do total de casos novos de tuberculose estimados pela OMS, menos da metade são notificados, denotando insuficiência nas políticas de controle da doença ${ }^{26}$.

A previsão foi de que 30 milhões de pessoas morreriam de tuberculose na década de 1990-1999, incluindo 2,9 milhões (9,7\%), devido à infecção pelo HIV $^{9,19,22,36,47,60}$, das quais 2,4 milhões de mortes por HIV ocorreriam na África ${ }^{18,36}$.

No final do ano 2000, estimou-se que 36 milhões de pessoas, no mundo todo, estariam infectadas pelo HIV, sendo que 12 milhões, aproximadamente, estariam coinfectadas com $M$. tuberculosis. Destes 12 milhões de pessoas co-infectadas, 8,4 milhões (70\%) viviam na África Subsaariana ${ }^{23}$.

A África do Sul é o país com o maior número de casos de HIV no mundo. Estimou-se que ocorreram 228.000 novos casos de tuberculose no ano 2000 (9\% a 
mais do que em anos anteriores), e que $60 \%$ dos pacientes de tuberculose estavam co-infectados com o HIV ${ }^{18,36}$.

Caso a gravidade deste quadro não se reverta, estima-se que até 2020, um bilhão de pessoas estarão infectadas pelo M. tuberculosis, 200 milhões adoecerão e 35 milhões irão morrer ${ }^{26}$.

A OMS assinala como principais causas para a gravidade da situação atual da tuberculose no mundo, as desigualdades sociais, o advento da AIDS, o envelhecimento da população e os grandes movimentos migratórios ${ }^{66}$.

Nos países industrializados, a tuberculose é resultante de uma infecção contraída no passado. Por este motivo, aproximadamente $80 \%$ dos infectados, têm mais de 50 anos de idade. Apenas uma pequena percentagem de todos os casos é atribuída à uma infecção recente, sendo que esses casos ocorrem, principalmente, em minorias étnicas e migrantes ${ }^{36}$.

Nos países em desenvolvimento, o risco de infecção permanece alto e a tuberculose aflige todas as faixas etárias ${ }^{36}$.

Até a década de 80, diferentemente dos países em desenvolvimento, os países desenvolvidos apresentaram constante declínio nos indicadores da doença, em grande parte devido ao desenvolvimento econômico, às melhorias nas condições de moradia (com menor aglomeração e melhor ventilação) e melhor nutrição ${ }^{73}$.

Este declínio, entretanto, acabou gerando uma despreocupação com a doença, falta de prioridade política para os programas da tuberculose, e conseqüente prejuízo no controle da doença ${ }^{16}$.

Neste contexto, surgem a epidemia de infecção pelo HIV e o aparecimento de cepas multidroga-resistentes do bacilo, atribuindo outra dimensão ao problema da tuberculose $\mathrm{e}^{75}$.

Por convenção, multidroga-resistência é definida como a resistência à pelo menos isoniazida e rifampicina, as mais importantes drogas antituberculose $\mathrm{e}^{39,51}$. Clinicamente, a resistência às drogas pode ser dividida em 2 tipos: resistência primária e resistência adquirida. A resistência primária ocorre em pessoas que nunca receberam tratamento para tuberculose e, portanto, se infectaram com uma cepa resistente de $M$. tuberculosis. Resistência adquirida é desenvolvida durante o tratamento, pelo uso inadequado das drogas antituberculose ${ }^{51}$. 
É improvável, que uma nova droga antituberculose esteja disponível em um futuro próximo. Se a resistência à rifampicina, a mais efetiva droga antituberculose, se difundir de uma maneira incontrolável, a tuberculose poderá se tornar incurável ${ }^{39}$.

Nos Estados Unidos da América, após a década de 80, as maiores taxas de tuberculose ocorreram entre imigrantes, refugiados e outros estrangeiros residentes no país. Segundo o CDC (Centers for Disease Control and Prevention), os estrangeiros residentes, especialmente Mexicanos, Filipinos e Vietnamitas, foram responsáveis por $46 \%$ dos 16.377 novos casos da doença ocorridos nos Estados Unidos no ano de 2000, e por $72 \%$ dos 141 casos de multidroga-resistentes. A taxa de infecção neste grupo foi 7 vezes maior do que nos nascidos no país ${ }^{32}$.

Segundo RUFFINO-NETTO ${ }^{65,66} 1999$, 2000, a tuberculose foi introduzida no Brasil pelos portugueses e missionários jesuítas durante sua colonização, em 1500. No início do século 19, praticamente um terço dos óbitos eram devidos à esta enfermidade e a assistência se dava através de organizações filantrópicas. No final da década de 10, foi criada a Inspetoria de Profilaxia da Tuberculose.

Em 1941, foi criado o Serviço Nacional de Tuberculose (SNT) e em 1946 a Campanha Nacional Contra a Tuberculose (CNCT). Em 1970 o SNT se transformou na Divisão Nacional de Tuberculose (DNT) e em 1976, em Divisão Nacional de Pneumologia Sanitária ${ }^{53,65,66}$.

Em 1990, foi criada a Coordenação Nacional de Pneumologia Sanitária (CNPS). Quando em 1993, a OMS declarou o estado de urgência da tuberculose, o Ministério da Saúde do Brasil, elaborou o Plano Emergencial para o controle da doença, que foi implantado, efetivamente, a partir de $1996^{65,66}$.

Os objetivos deste Plano eram que $100 \%$ dos municípios tivessem ações de diagnóstico e tratamento, $80 \%$ dos centros de saúde desenvolvessem essas ações, 90\% dos casos existentes fossem diagnosticados, e que $85 \%$ dos casos tratados fossem curados ${ }^{47,64,65}$.

Até 1995, o Programa Nacional de Controle da Tuberculose alcançou a vacinação de $90 \%$ dos menores de 1 ano, a descoberta de $75 \%$ dos casos estimados e sucesso terapêutico em $75 \%$ dos pacientes que iniciaram tratamento ${ }^{47}$.

Segundo RUFFINO-NETTO ${ }^{64,65}$ 1999, "no período de 1977-1982, o coeficiente de incidência de tuberculose aumentou e o coeficiente de mortalidade 
caiu; portanto, o coeficiente de letalidade deveria ter sofrido um grande declínio. Como no período que se segue (1982-1995) a letalidade permaneceu constante, supõe-se que a mortalidade estaria subnotificada no período anterior. Nestes últimos 20 anos, observa-se que o percentual de abandono do tratamento manteve-se em níveis elevados, mais ou menos estáveis, ao redor de 14\%".

O Brasil é o décimo país do mundo em número de casos, com cerca de 90.000 casos novos e mais de 5.000 mortes anuais ${ }^{47}$. Em 2000, foram notificados 82.249 casos novos de tuberculose, com um coeficiente de incidência de 48,4/100.000 ${ }^{12,26}$.

Destes 90.000 casos novos, $48 \%$ se encontram na região sudeste, da qual faz parte o Estado de São Paulo, que por sua vez possui o maior número absoluto de casos do país, apresentando na última década uma incidência de cerca de 17.000 casos novos por ano e um coeficiente oscilando entre 50 e 60/100.000 habitantes ${ }^{21}$.

Segundo dados provisórios, fornecidos pelo CVE (Centro de Vigilância Epidemiológica), da Secretaria de Saúde do Estado de São Paulo, referentes ao ano de 2002, o total de casos (novos e retratamentos) de tuberculose notificados, na população do Estado, foi de 20.477 casos, e a incidência de 17.840 casos novos, sendo 46,8/100.000 habitantes, o coeficiente de incidência ${ }^{72}$.

Em outubro de 1998, o Ministério da Saúde apresentou o Plano Nacional de Controle da Tuberculose, adotando a estratégia DOTS, recomendada pela OMS. As metas do Plano Nacional eram as seguintes: implementar as atividades de controle da doença em 100\% dos municípios do país; detectar 92\% dos casos existentes até o ano de 2002; curar $85 \%$ dos casos novos detectados; reduzir a incidência à metade do seu valor e a mortalidade em dois terços, até o ano 2007. O Plano introduziu duas inovações: o tratamento supervisionado e a instituição de um bônus aos municípios, para cada caso de doente de tuberculose diagnosticado, tratado e curado ${ }^{64,65,66}$.

O objetivo do novo plano mundial de combate à tuberculose, para 2005, denominado "WHO's Stop TB", é que 70\% dos novos casos de tuberculose sejam diagnosticados e $85 \%$ dos tratados, sejam $\operatorname{curados}^{18}$.

Por ser a tuberculose pulmonar a forma mais freqüente da doença, o principal material biológico investigado é o escarro de sintomáticos respiratórios (pessoas com tosse e expectoração por 3 semanas ou mais) ${ }^{12,46,49,71}$, grupo de grande interesse, pois oferece maior rendimento na descoberta de $\operatorname{casos}^{45,46,47,71}$. 
Face à alta prevalência da tuberculose no Brasil, há a necessidade de utilização de métodos laboratoriais simples, rápidos, confiáveis e pouco onerosos, para o diagnóstico da tuberculose pulmonar. Apesar de existirem outras metodologias mais sofisticadas e modernas, ainda hoje a pesquisa bacteriológica (baciloscopia e cultura) é prioritária ${ }^{45,46,47,48}$.

Atualmente, a tuberculose é uma doença ainda grave, porém curável em praticamente $100 \%$ dos casos novos, desde que obedecidos os princípios da moderna quimioterapia. A associação medicamentosa adequada e seu uso regular, por tempo suficiente, são os meios necessários para evitar a resistência e a persistência bacterianas $^{47}$.

Desde 1998, a tuberculose tem se destacado na agenda internacional. Em 2000, em uma conferência realizada em Amsterdã, da qual participaram ministros de 20 dos 23 países mais ricos, além de entidades internacionais, foi apontada a urgência do controle da tuberculose ${ }^{7}$. Nesta reunião, reiterou-se o compromisso dos países envolvidos em priorizar a luta contra a doença, e enfatizou-se a importância de se buscar parceiros em organizações não-governamentais (ONGs), para a realização desta tarefa ${ }^{66}$.

Também em 2000, evocou-se a intensificação de esforços mundiais contra a tuberculose, a infecção pelo HIV, e malária; com o objetivo de se reduzir em 50\% a mortalidade por tuberculose em 2010. Objetivo este, difícil de alcançar, apesar da estratégia "WHO DOTS", disponibilizada pela Organização Mundial da Saúde, cujos principais componentes são: um maior comprometimento político para o combate à tuberculose; a detecção de casos da doença nos sintomáticos respiratórios; tratamento diretamente observado de curta duração (considerada a intervenção de maior impacto no combate à tuberculose); a garantia de um fornecimento regular das drogas antituberculose, além de um adequado sistema de vigilância e monitoramento da doença $^{7,66}$.

Atualmente, a tuberculose está intimamente ligada à infecção pelo HIV, pois ela é a principal causa de morbidade e mortalidade em pacientes HIV-positivos. A infecção pelo HIV é um "combustível” para a tuberculose, portanto, sua prevenção deveria se tornar uma prioridade nos programas de controle da tuberculose; tanto 
quanto a vigilância e prevenção da tuberculose, deveria ser a principal preocupação dos programas HIV/AIDS ${ }^{7,23}$.

Para atingir este objetivo, a OMS está coordenando uma estratégia denominada "Iniciativa ProTEST", que consiste na oferta de testes voluntários para HIV no momento da detecção de casos de tuberculose, além do tratamento dos casos diagnosticados e tratamento preventivo com isoniazida para os infectados com $M$. tuberculosis, mas sem tuberculose ativa ${ }^{23}$.

A implementação dos primeiros projetos, ocorrerá na África do Sul, Malawi, Uganda e Zâmbia. Estes locais servirão de base para a aplicação, em grande escala, do amplo conjunto de intervenções que o controle da tuberculose exige, especialmente nos países com alta prevalência de $\mathrm{HIV}^{23}$.

Outra preocupação mundial é a droga-resistência do bacilo da tuberculose. Em abril de 2002, a Organização Mundial da Saúde e a União Internacional Contra a Tuberculose realizaram um levantamento em 72 países, para conhecerem a distribuição mundial da tuberculose droga-resistente ${ }^{51}$.

Observaram que, nos casos novos de tuberculose, a prevalência da resistência à pelo menos uma droga antituberculose variou de $1,7 \%$ no Uruguai a 36,9\% na Estônia $^{51}$.

Entretanto, a prevalência média global de tuberculose multidroga-resistente entre estes casos novos de droga-resistência, foi de apenas $1 \%{ }^{51}$.

Os países com as maiores prevalências de tuberculose multirresistente (TBMDR), entre os casos novos, foram Estônia (14\%), Latvia (9\%), Ivanovo (9\%) e Tomsk Oblats (6,5\%) na Federação Russa, e Henan Province (11\%) na China ${ }^{26,51}$.

O Brasil ficou entre os 14 países com prevalência maior que 3\% de TB-MDR, entre os casos novos de droga-resistência ${ }^{51}$. No período de 1994 a 1999, o Brasil possuía uma resistência primária de $1,1 \%$, resistência adquirida de $8,2 \%$ e resistência combinada de $2,2 \%^{26}$.

A tuberculose sempre foi um grave problema de saúde para grupos de pessoas que permanecem confinadas, especialmente em presídios, devido à sua transmissão respiratória. Por este motivo, uma atenção especial deve ser dispensada à esta população ${ }^{8,42,74,76}$. 
Estima-se que a população mundial encarcerada esteja em torno de 8 a 10 milhões de presos, e tudo indica que ela está crescendo. Quase metade destes presos estão nos Estados Unidos (1,7 milhões), China (1,4 milhões) e Rússia (1 milhão) ${ }^{39,80}$.

A Rússia tem a maior taxa de população prisional do mundo, com 690 presos por 100.000 pessoas da população nacional, seguida pelos Estados Unidos $(668 / 100.000)$ e África do Sul $(327 / 100.000)^{6}$. Em relação aos outros países, 65\% têm taxas menores ou iguais a 150/100.000. Nos países da América do Sul, a taxa média é de 110/100.000, mas nos países do Caribe é de 330/100.000 ${ }^{80}$.

No Brasil, a taxa de população prisional em 2003, foi de 168/100.000 habitantes, mas no Estado de São Paulo, foi de 320/100.000 ${ }^{43}$.

As populações prisionais são compostas, predominantemente, por homens, na faixa etária de 15-44 anos, que geralmente representam grupos marginalizados de uma comunidade civil, como minorias étnicas, imigrantes ilegais, usuários de drogas, doentes mentais e indigentes ${ }^{6}$.

As prisões, em sua maioria, são locais superlotados, pouco ventilados e com baixos padrões de higiene e limpeza. A nutrição é inadequada e comportamentos ilegais, como o uso de álcool e drogas ou atividades sexuais (com ou sem consentimento), não são reprimidos. Estas condições são perfeitas para surtos de doenças como tuberculose e HIV $\mathrm{HV}^{6,37,61}$.

O confinamento nas prisões, freqüentemente, gera comunidades violentas, nas quais regras não oficiais são impostas pela força, por uma hierarquia interna. A superlotação, a falta de provisões básicas e de respeito pelos direitos dos prisioneiros, além do isolamento da família e amigos, são fatores agravantes da violência, da corrupção e da promiscuidade, que ocorrem nos presídios. Depressão, ansiedade e psicoses, são muito mais comuns na população prisional do que na população geral $^{6,14}$. Para os familiares do preso, a prisão do "chefe da família" acarreta, além do estigma, problemas emocionais, psicológicos e comportamentais nas crianças e em outros membros da família ${ }^{15}$.

Devido a estas condições, estudos realizados desde 1944 em várias partes do mundo, já apontavam uma prevalência e incidência da tuberculose muito maior na população prisional do que na população geral ${ }^{8,42,74,76}$. 
Estima-se que, anualmente, ocorrem 75.000 casos novos de tuberculose na população civil da Rússia, que é de 150 milhões de pessoas (50 casos/100.000 habitantes). Entretanto, nas prisões russas ocorrem 40.000 novos casos para uma população de 1 milhão de presos (4.000 casos/100.000 presos). Ou seja, a incidência de tuberculose entre os presidiários da Rússia é 80 vezes maior do que na população geral $^{14}$.

AERTS e col. ${ }^{2}$, 2000, realizaram um estudo em 12 colônias para presos sentenciados, no Estado da Geórgia (ex União Soviética), no período de 1997-1998, e encontraram uma prevalência de tuberculose de 5.995/100.000 presos, que foi quase 200 vezes maior do que na população geral do Estado, que era de 34,3/100.000 habitantes. Na Geórgia, o excesso de risco para tuberculose entre prisioneiros não tem precedentes, e sugere que estes representam um reservatório importantíssimo da doença.

Segundo a $\mathrm{OMS}^{6}$ 2000, estudos realizados em outros países, também apontaram uma prevalência maior da doença na população carcerária, como por exemplo:

- Brasil (1992-1993) - 5.714 casos/100.000 presos, ou seja, 102,2 vezes mais que na população geral (55,9 casos/100.000 habitantes).

- Malawi (1996) - 5.142 casos/100.000 presos, ou seja, 24,5 vezes mais que na população geral (209,5 casos/100.000 habitantes).

- Ruanda (1996-1998) - 3.363 casos/100.000 presos, ou seja, 42,4 vezes mais que na população geral (79,3 casos/100.000 habitantes).

- Madri (1993-1994) - 2.283 casos/100.000 presos, ou seja, 95,1 vezes mais que na população geral (24 casos/100.000 habitantes).

- Nova York (1991) - 156,2 casos/100.000 presos, ou seja, 15 vezes mais que na população geral $(10,4 \text { casos/100.000 habitantes })^{6}$.

De acordo com AUSINA e CAYLÀ ${ }^{4}$ 2000, as maiores incidências de tuberculose na população prisional são encontradas nos países africanos e na antiga União Soviética, com taxas entre 2.400 e 7.200 casos novos de tuberculose por 100.000 presos. Em algumas prisões da Rússia, a mortalidade por tuberculose é de $24 \%$. 
As prisões da Rússia foram consideradas pelo microbiologista americano Alex Goldfarb "o epicentro de uma epidemia mundial de multidroga-resistência”, pois, cerca de $20 \%$ dos prisioneiros russos são suspeitos de abrigarem variedades de cepas droga-resistentes, particularmente a família "W", identificada em Nova York durante uma epidemia de tuberculose entre vítimas de AIDS, no início de $1990^{27}$.

PORTAELS e col. ${ }^{58}$ 1999, realizaram um estudo nas prisões de Baku (Azerbaijão) e Mariinsk (Sibéria), na ex União Soviética. Foram analisados escarros de presos recentemente tuberculosos que estavam iniciando o tratamento, e de presos doentes que não respondiam ao tratamento.

A taxa de TB-MDR entre os presos que estavam iniciando o tratamento em Baku e Mariinsk, foi de 23,7\% e 26,3\%, respectivamente ${ }^{58}$.

Entre os que não respondiam ao tratamento, 89,3\% em Baku e 94,2\% em Mariinsk, tinham TB-MDR ${ }^{58}$.

Testes de RFLP (Restriction Fragment Lenght Polymorphism) das cepas dos prisioneiros de Mariinsk revelaram que todos os pacientes com TB-MDR primária e adquirida eram portadores de cepas geneticamente idênticas, o que sugeriu que os novos prisioneiros haviam sido infectados por cepas multi-resistentes no sistema prisional e desenvolveram uma TB-MDR primária ${ }^{58}$.

KIMERLING e col. ${ }^{35} 1999$, durante o período 1997-1998, encontraram entre 164 detentos tuberculosos da prisão de Mariinsk (Sibéria), uma resistência inicial à isoniazida de $66 \%$, e à isoniazida e rifampicina, de 22,6\%. Apenas $25 \%$ dos pacientes, eram sensíveis à todas as drogas testadas.

AERTS e col. ${ }^{2}$ 2000, observaram também que, dos 448 casos de tuberculose entre os prisioneiros estudados, 77,9\% eram resistentes à pelo menos uma droga antituberculose e $13 \%$ eram TB-MDR.

PFYFFER e col. ${ }^{55}$ 2001, analisaram cepas de 65 dos 300 pacientes de tuberculose do Hospital Penitenciário Central de Baku (Azerbaijão), e a multidrogaresistência, envolvendo isoniazida e rifampicina, foi observada em 52,3\% dos isolamentos. 
Nos Estados Unidos da América, ocorreram 3 surtos de TB-MDR no sistema correcional do Estado de Nova York, no período de 1990-1991, com altas taxas de mortalidade, envolvendo 39 presos, pelo menos um funcionário, e 23 presídios ${ }^{33}$.

No mesmo período, uma possível transmissão de TB-MDR ocorreu em uma prisão da Califórnia entre presos e funcionários; e em outra prisão da Califórnia, a incidência de tuberculose foi 184/100.000, dez vezes mais que a incidência na comunidade $^{33}$.

No Brasil, o MINISTÉRIO DA SAÚDE ${ }^{47}$ 1995, recomenda em seu "Manual de Normas para o Controle da Tuberculose", uma atenção especial aos grupos de maior risco de adoecimento, representados, sobretudo, por portadores do HIV e pacientes com AIDS, comunidades fechadas como presídios, manicômios, abrigos e asilos, sendo que nessas comunidades justifica-se a periódica busca ativa de casos.

Em nosso país, o número de presos por 100.000 habitantes vem crescendo sistematicamente, passando de 95,4 em 1995 para 108,6 presos por 100.000 habitantes em 1997, e para 168,0 por 100.000 habitantes em junho de 2003. Em números totais, o aumento foi de 148.760 em 1995 para 170.602 presos em 1997, e para 284.989 em junho de 2003, a um custo médio mensal, em reais, equivalentes a U\$268,86 dólares por preso ${ }^{42,43}$.

Apesar dos esforços conjuntos dos Governos Federal e Estaduais para a construção de novos estabelecimentos prisionais, o déficit de vagas no sistema penitenciário brasileiro cresceu de 75.887 em 1995 para 96.010 em 1997, e para 104.263 em junho de 2003; ou seja, o ingresso de presos no sistema vem acontecendo em ritmo muito mais acelerado do que sua saída ${ }^{42,43}$.

Esses números refletem uma série de circunstâncias, mas estão principalmente relacionados com o agravamento das penas, com a mínima aplicação das penas alternativas e com crescentes dificuldades relativas à concessão de benefícios, como o livramento condicional, nos prazos estabelecidos pela legislação ${ }^{29,70}$.

Normalmente, um preso que inicia o cumprimento de sua sentença em regime fechado, após cumprir uma parte da pena, deveria ser transferido para um estabelecimento de regime semi-aberto e de lá, após mais um tempo, para um de regime aberto e finalmente, retornar à sociedade. Entretanto, grande parte dos presos 
nunca esteve em estabelecimentos de regimes aberto ou semi-aberto, cumprindo toda sua pena em uma prisão de regime fechado ou em Distritos Policiais ${ }^{29}$.

Consequentemente, as celas dos Distritos Policiais em praticamente todos os Estados, estão superlotadas, com presos amontoados, uns aguardando julgamento e outros já condenados, em total desrespeito às mínimas condições de dignidade humana e à Lei de Execução Penal (Lei 7.210 de 1984), além de constituir flagrante desvio de função da Polícia ${ }^{42}$.

O Estado de São Paulo abriga 39,7\% da população carcerária do país ${ }^{29,42}$. Em 1997, o número total de presos do Estado era de 67.786, sendo que o sistema prisional oferecia apenas 24.222 vagas; havendo, portanto, na época, um déficit de 43.564 vagas $^{42}$. Segundo dados disponibilizados pelo Departamento Penitenciário Nacional $^{43}$ 2003, referentes a junho de 2003, o número total de presos do Estado aumentou para 118.389, e as vagas disponíveis aumentaram para 74.730; entretanto, o déficit de 43.659 vagas manteve-se praticamente o mesmo.

Em 1997, do total de 67.786 presos, 35.847 estavam distribuídos em 59 Penitenciárias, sendo 4 destas femininas, subordinadas à Secretaria de Estado da Administração Penitenciária. Os outros 31.939 detentos estavam nas Cadeias Públicas e Distritos Policiais (Delegacias de Polícia), subordinados à Secretaria de Estado da Segurança Pública ${ }^{42}$.

Em junho de 2003, do total de 118.389 presos, 90.206 estavam distribuídos em 117 Penitenciárias e 28.183 em Cadeias Públicas e Distritos Policiais ${ }^{43}$.

Em teoria, a rota de um preso pelo sistema penal deveria seguir um curso previsível: logo após ser preso, o suspeito criminoso deveria ser levado à Delegacia de Polícia (Distrito Policial) para registro e detenção inicial. Dentro de poucos dias, caso não fosse libertado, deveria ser transferido para uma Cadeia ou Casa de Detenção enquanto aguardasse julgamento e sentenciamento. Se condenado, ele deveria ser transferido para uma Penitenciária ${ }^{29}$.

Entretanto, a nossa realidade, passa longe das descrições da lei. No sistema penal do Brasil falta infra-estrutura física necessária para garantir o cumprimento da lei, não existindo vagas suficientes nos presídios para suportar o número de detentos, forçando muitos presos condenados a permanecerem em Distritos Policiais durante $\operatorname{anos}^{29}$. 
Enquanto em São Paulo, aproximadamente, 24\% dos presos do Estado são mantidos em Distritos Policiais, em Minas Gerais que possui a terceira maior população carcerária do Brasil, esta percentagem é de $82 \%{ }^{29}$.

Os detentos brasileiros são, em sua maioria, homens na faixa etária de 20 a 49 anos, com pouca escolaridade e provenientes de grupos de baixo nível sócioeconômico. As condições de vida nas prisões, com aglomeração e baixos padrões de higiene, submetem essa população à um alto risco de adoecimento e morte. $\mathrm{O}$ consumo de drogas injetáveis e sexo sem proteção são práticas comuns e, consequentemente, favorecem a transmissão da infecção pelo $\mathrm{HIV}^{39}$.

No final de 1997, pesquisadores da Universidade de São Paulo, estimaram que cerca de $20 \%$ da população carcerária do Brasil, estava infectada pelo HIV. Em alguns presídios de São Paulo, a percentagem de presos infectados pelo HIV, foi de $30 \%{ }^{29,50}$.

Um fator importante a ser destacado é a extrema mobilidade desta população, circulando de uma prisão a outra e retornando ao convívio social. A média de permanência nos Presídios é de aproximadamente 30 meses. Nas Cadeias Públicas e Distritos Policiais não existe informação sobre a rotatividade do sistema, mas acredita-se que seja alta ${ }^{39,70}$.

As análises mais isentas de diversos especialistas em sistema prisional, atestam a falência do sistema prisional brasileiro. A situação não se reflete apenas nas condições subumanas em que vivem os presos. O regime de violência a que estão submetidos, impedem sua recuperação. $O$ detento não se ressocializa e ainda encontra condições de progredir no crime, a partir do momento em que é preso ${ }^{50}$.

Consequentemente, o percentual de reincidência entre os egressos do sistema prisional nacional, segue aumentando. Em São Paulo, ele é superior a $80 \%{ }^{50}$.

No Brasil, reincidentes violentos e réus primários, detidos por delitos menores, freqüentemente dividem a mesma cela. Situação esta que, aliada às condições peculiares das prisões, à ausência de supervisão efetiva, à existência de armas nas mãos dos presos, e à falta de atividades, resulta em situações de abuso entre os detentos. Os prisioneiros mais fracos ou menos poderosos, freqüentemente, têm que pagar a outros presos por certos "privilégios"; para tanto, seus pertences pessoais são constantemente tirados deles ${ }^{29}$. 
A precariedade da assistência médica é outro aspecto bastante preocupante. Doenças potencialmente letais como a tuberculose e a AIDS atingiram níveis epidêmicos entre a população carcerária do Brasil. Ao dificultar um tratamento adequado aos presos, o sistema prisional não apenas ameaça a vida dos detentos, como também facilita a transmissão dessas doenças à população em geral, através das visitas conjugais e do livramento dos presos. Como os detentos não estão completamente isolados do mundo exterior, uma contaminação não controlada entre eles representa um grave risco à saúde pública ${ }^{29}$.

Em relação à tuberculose, segundo a SECRETARIA DE ESTADO DA SAÚDE ${ }^{70} 1999$, nas "Recomendações para o controle da tuberculose nas prisões", a maior parte dos detentos em nosso país ingressam nas prisões já infectados pelo Mycobacterium tuberculosis e as condições de confinamento favorecem tanto a evolução de infecção para doença, como a sua transmissão. Os profissionais que trabalham no sistema prisional e os visitantes, são também submetidos à altos riscos de contrair tuberculose.

No Estado de São Paulo, os dados existentes sobre a ocorrência da tuberculose no sistema prisional, não são fidedignos. O registro de casos para o sistema de notificação, bem como o resultado de tratamentos, são subnotificados. Na ausência de dados da rotina, a informação sobre tuberculose nas prisões provém de estudos efetuados em determinados locais, e descritos nas "Recomendações para o controle da tuberculose nas prisões"70 1999 :

- "No Estado de São Paulo, Niero, em estudo realizado na Casa de Detenção de São Paulo de 1976 a 1980, em mais de 9.000 presos, encontrou uma incidência anual média de tuberculose pulmonar bacilífera de 1.073/100.000 presos/ano. E uma incidência anual de infecção tuberculosa de 71,9\%".

- "Entre outubro de 1992 e novembro de 1993, estudo de coorte realizado no Presídio Feminino de São Paulo, encontrou uma incidência de tuberculose de 9,9 casos/100 pessoas-ano em presidiárias HIV-positivas e 0,7 casos/100 pessoas-ano entre as presidiárias HIV-negativas. A incidência de infecção foi de 30,9/100 presasano, sendo que $24,9 \%$ das presas eram HIV-positivas". 
- “Em 1993-1994, outro estudo realizado na Casa de Detenção de São Paulo, indicou uma incidência de 2.650 casos de tuberculose por 100.000 pessoas-ano, cerca de 50 vezes a incidência de tuberculose no Estado de São Paulo”.

Caso a incidência da tuberculose no sistema prisional seja da mesma dimensão encontrada nestes estudos, estima-se que o sistema contribua com 7.5\% dos casos de tuberculose do Estado. Se forem incluídos os casos transmitidos para a comunidade, esse número poderá chegar a 10\%, indicando a relevância e gravidade do problema ${ }^{70}$.

Segundo dados provisórios, fornecidos pelo CVE, a taxa de casos de tuberculose notificados na população carcerária do Estado de São Paulo, aumentou de 678,1/100.000 detentos em 2001, para 848,0/100.000 detentos em 2002. A taxa de casos novos notificados aumentou de 555,7/100.000 detentos em 2001, para 717,7/100.000 detentos em 2002.

As Cadeias e Distritos Policiais não têm sistema de saúde próprio. A responsabilidade pela saúde nestas instituições, embora estabelecida pela lei 8080 do Sistema Único de Saúde, não é assumida pelos níveis Municipal ou Estadual, quando necessário. Em geral, não contam com a mínima estrutura física para o atendimento aos doentes ${ }^{70}$.

Sabe-se pela mídia das péssimas condições carcerárias dos Distritos Policiais, com excessivo número de detentos vivendo em condições subumanas e espaço reduzido, sendo que em celas que deveriam abrigar 8 detentos existem mais de 30 . Sabe-se também, que a tuberculose está extremamente relacionada com aglomeração e condições precárias de moradia.

Os detentos desses locais vivem, segundo comunicação pessoal, em condições bastante precárias e com muitas doenças transmissíveis. Não há assistência médica formal e quando um detento fica doente tem que ser levado a um Pronto-Socorro que muitas vezes não o aceita por problemas de segurança, como resgate do preso por quadrilhas especializadas. Além disso, o detento tem que ser acompanhado por um Investigador da Polícia Civil, causando transtornos ao serviço.

Os Investigadores também levam os detentos às audiências na Justiça e aos exames de corpo de delito no Instituto Médico-Legal, que são obrigatórios no ingresso e na saída do preso do Distrito Policial, além de revistarem as celas diariamente em busca de armas e túneis em construção. Sem a carceragem das 
Delegacias, mais policiais estariam apurando e resolvendo crimes, pois o tempo gasto nos cuidados com os presos, os desviam de suas missões de investigação ${ }^{24,29}$.

O sistema está tão sobrecarregado, que doentes em estado grave ou mesmo em estado terminal permanecem juntos aos demais detentos nos Distritos Policiais. Apenas uma minoria de presos com doenças graves são levados ao Hospital Penitenciário, localizado no complexo da Penitenciária do Estado, que possui apenas 84 celas $^{29}$.

Esta dificuldade de diagnóstico e tratamento da tuberculose nos Distritos Policiais tem ocasionado um número cada vez maior de casos graves e óbitos nos últimos tempos.

A variada periculosidade da população carcerária, aliada às complexas relações entre aprisionados, profissionais responsáveis pela segurança e diretoria da unidade, resultam em dificuldades para o trabalho dos profissionais de saúde junto aos presos. Consequentemente, os casos bacilíferos raramente são diagnosticados e, quando isto ocorre, a falta de controle ou a interrupção do tratamento perpetuam a fonte de infecção e aumenta o risco de casos resistentes às drogas ${ }^{70}$.

A quimioterapia deve impedir o desenvolvimento da resistência bacteriana, obter o mais rapidamente possível a negativação bacteriológica, conseguir a cura e evitar recaídas ${ }^{71,75}$. A interrupção precoce do tratamento possibilita a multiplicação das micobactérias que se encontravam em estado de semilatência, causando a recidiva da tuberculose $\mathrm{s}^{46,62,71}$.

A visão social predominante é a de que os presidiários merecem punição. Assim, não há investimentos de recursos para a melhoria do atendimento da população prisional em detrimento da população geral, fato que tem contribuído para a falta de motivação para resolver o problema ${ }^{70}$.

Não existem estudos a respeito da população carcerária dos Distritos Policiais da Cidade de São Paulo. Os levantamentos existentes são referentes à população da Casa de Detenção ou dos presídios que possuem assistência médica e oferecem melhores condições de vida.

A preocupação com a situação da tuberculose na população carcerária dos Distritos Policiais da Cidade de São Paulo e a necessidade de conhecer a prevalência da doença e o índice de infecção tuberculosa nessa população, aliadas às 
características físicas, sociais e criminais dos detentos, visando colaborar com a adoção de ações efetivas de combate a essa endemia, foram objetos deste estudo. 


\section{2- OBJETIVOS}

\section{1- Geral}

Estudar a situação da tuberculose nos detentos dos Distritos Policiais da Zona Oeste da Cidade de São Paulo.

\section{2- Específicos}

- Analisar as características físicas, sociais e criminais da população carcerária dos Distritos Policiais da Zona Oeste da Cidade de São Paulo.

- Verificar a prevalência de detentos infectados pelo Mycobacterium tuberculosis.

- Verificar a prevalência de doentes de tuberculose nestes Distritos Policiais.

- Identificar as cepas de micobactérias isoladas das culturas de escarro dos detentos.

- Averiguar a resistência bacteriana das cepas de M. tuberculosis isoladas, utilizando o teste de sensibilidade às drogas antituberculose. 


\section{3- MATERIAL E MÉTODOS}

\section{1- População de Estudo}

O objeto deste estudo, realizado no período de março de 2000 a maio de 2001, foi a população carcerária dos Distritos Policiais da Zona Oeste da Cidade de São Paulo, pertencentes à $3^{\mathrm{a}}$ Delegacia Seccional de Polícia - Oeste, e subordinados à Secretaria de Estado da Segurança Pública do Estado.

Segundo a Secretaria de Estado da Segurança Pública, a Zona Oeste da Cidade de São Paulo, abrange os Distritos Censitários de: Perus, Anhanguera, Jaraguá, Pirituba, São Domingos, Jaguara, Jaguaré, Vila Leopoldina, Lapa, Perdizes, Alto de Pinheiros, Pinheiros, Jardim Paulista, Itaim Bibi, Raposo Tavares, Vila Sônia, Rio Pequeno, Butantã, Morumbi, Vila Andrade, Campo Limpo, parte dos Distritos da Barra Funda, parte da Consolação e parte de Moema.

No período de estudo, havia 14 Distritos Policiais (DP) situados na Zona Oeste da Cidade de São Paulo, mas apenas 9 possuíam carceragem, ou seja, abrigavam detentos em suas dependências. Eram os seguintes: $7^{\circ} \mathrm{DP}$ - Lapa, $14^{\circ} \mathrm{DP}$ - Pinheiros, $33^{\circ}$ DP - Pirituba, $34^{\circ}$ DP - Morumbi, $37^{\circ}$ DP - Campo Limpo, $46^{\circ} \mathrm{DP}$ Perus, $87^{\circ}$ DP - Pereira Barreto, $91^{\circ}$ DP - Ceasa e o $89^{\circ}$ DP - Portal do Morumbi que era o único feminino da região.

\section{2- Caracterização dos Distritos Policiais}

A carceragem dos 9 Distritos Policiais da Zona Oeste da Cidade de São Paulo, era constituída por:

- um local de acesso, totalmente gradeado, como uma gaiola, denominado "viúva". Nele os advogados e policiais se comunicavam com os presos. Neste local realizamos nosso trabalho, evitando assim um contato corporal com os detentos.

- um pátio interno rodeado por celas gradeadas, denominadas "xadrez" pelos detentos e policiais. Todas as celas possuíam uma pequena copa e um banheiro, que era referido como "boi".

- uma cela especial, próxima à supervisão dos guardas ou dentro da "viúva", denominada "corró" ou "seguro", que abrigava os presos jurados de morte pelos outros detentos e os travestis, denominados presos "seguros". 
- em 2 Distritos Policiais, as carceragens possuíam uma cela especial ligada ao pátio e também denominada "corró" ou "seguro", que abrigava presos de confiança. Estes detentos podiam circular livremente pelo pátio, a qualquer hora do dia ou da noite.

- em 1 Distrito Policial, havia uma sala especial para a realização de revistas nas visitas recebidas pelos presos. Nos outros, o local para a revista era improvisado.

\subsection{1- $7^{\circ}$ Distrito Policial - Lapa}

A carceragem do $7^{\circ}$ Distrito Policial possuía:

-1 local de acesso à carceragem, totalmente gradeado ("viúva"), medindo $3,10 \mathrm{~m} \times 1,45 \mathrm{~m}$, totalizando $4,50 \mathrm{~m}^{2}$.

-1 pátio interno, medindo $12,90 \mathrm{~m} \times 5,90 \mathrm{~m}$, totalizando $76,11 \mathrm{~m}^{2}$. Entretanto, apenas $34,35 \mathrm{~m}^{2}$ da área total era descoberta, permitindo a entrada de luz. O restante da área $\left(41,76 \mathrm{~m}^{2}\right)$ era constituída por marquises sobre as celas e o tanque de lavar roupas.

-5 celas (ou "xadrez") medindo 5,05m x 3,90m e contendo uma pequena copa e banheiro (ou "boi"), totalizando $19,70 \mathrm{~m}^{2}$, cada uma.

-1 "corró" interno (ou "seguro"), para presos de confiança, pouco utilizado, medindo $3,90 \mathrm{~m} \times 2,50 \mathrm{~m}$, com banheiro, totalizando $9,75 \mathrm{~m}^{2}$.

-1 "corró" externo (ou "seguro"), para presos jurados de morte e travestis, medindo $2,10 \mathrm{~m} \times 1,48 \mathrm{~m}$, com banheiro, totalizando $3,11 \mathrm{~m}^{2}$.

\subsection{2- $14^{\circ}$ Distrito Policial - Pinheiros}

A carceragem do $14^{\circ}$ Distrito Policial possuía:

-1 "viúva" pequena, de aproximadamente $2,00 \mathrm{~m}^{2}$, localizada na sala do carcereiro.

-1 pátio interno, medindo $12,80 \mathrm{~m} \times 6,20 \mathrm{~m}$, totalizando $79,36 \mathrm{~m}^{2}$, descoberto, mas com uma tela de proteção feita de ferro, permitindo a entrada de luz.

-5 celas medindo 4,40m x 3,90m e contendo uma pequena copa e banheiro, totalizando $17,20 \mathrm{~m}^{2}$, cada uma. 
-1 "corró" interno, para presos de confiança, que podiam circular livremente pelo pátio, a qualquer hora do dia ou da noite, medindo $3,90 \mathrm{~m} \times 1,70 \mathrm{~m}$, com banheiro, totalizando $6,63 \mathrm{~m}^{2}$.

\subsection{3- 33 ${ }^{\circ}$ Distrito Policial - Pirituba}

A carceragem do $33^{\circ}$ Distrito Policial possuía:

-1 sala para revista das visitas, medindo $4,20 \mathrm{~m} \times 3,20 \mathrm{~m}$, totalizando $13,44 \mathrm{~m}^{2}$.

-1 "viúva", medindo $6,00 \mathrm{~m} \times 1,80 \mathrm{~m}$, totalizando $10,80 \mathrm{~m}^{2}$.

-1 pátio interno, medindo $13,20 \mathrm{~m}$ x $6,00 \mathrm{~m}$, totalizando $79,20 \mathrm{~m}^{2}$, descoberto, mas com uma tela de proteção feita de ferro, permitindo a entrada de luz.

-3 celas medindo 4,40m x 4,20m e contendo uma pequena copa e banheiro, totalizando $18,48 \mathrm{~m}^{2}$, cada uma.

-2 celas medindo $5,00 \mathrm{~m}$ x 4,20m e contendo uma pequena copa e banheiro, totalizando $21,00 \mathrm{~m}^{2}$, cada uma.

-1 “corró" externo, medindo 4,20m x 1,80m, com banheiro, totalizando $7,56 \mathrm{~m}^{2}$.

\subsection{4- 34 ${ }^{\circ}$ Distrito Policial - Morumbi}

A carceragem do $34^{\circ}$ Distrito Policial possuía:

-1 “viúva", medindo $10,20 \mathrm{~m} \times 1,50 \mathrm{~m}$, totalizando $15,30 \mathrm{~m}^{2}$.

-1 pátio interno, medindo $12,00 \mathrm{~m} \times 6,20 \mathrm{~m}$, totalizando $74,40 \mathrm{~m}^{2}$, descoberto, mas com uma tela de proteção feita de ferro, permitindo a entrada de luz.

-6 celas (ou xadrez) medindo 4,00m x 3,70m e contendo uma pequena copa e banheiro, totalizando $14,80 \mathrm{~m}^{2}$, cada uma.

-1 "corró" externo, desativado na época da pesquisa, medindo 3,70m x $1,50 \mathrm{~m}$, com banheiro, totalizando $5,55 \mathrm{~m}^{2}$.

\subsection{5- 37 ${ }^{\circ}$ Distrito Policial - Campo Limpo}

A carceragem do $37^{\circ}$ Distrito Policial possuía:

-1 "viúva", medindo $8,00 \mathrm{~m} \times 2,00 \mathrm{~m}$, totalizando $16,00 \mathrm{~m}^{2}$. 
-1 pátio interno, medindo $13,00 \mathrm{~m} \times 6,00 \mathrm{~m}$, totalizando $78,00 \mathrm{~m}^{2}$. Entretanto, apenas $39,00 \mathrm{~m}^{2}$ da área total era descoberta, permitindo a entrada de luz. O restante da área $\left(39,00 \mathrm{~m}^{2}\right)$ era constituída por marquises sobre as celas.

-5 celas medindo $5,00 \mathrm{~m} \times 5,00 \mathrm{~m}$ e contendo uma pequena copa e banheiro, totalizando $25,00 \mathrm{~m}^{2}$, cada uma.

-1 “corró" externo, medindo 7,00m x 2,00m, com banheiro, totalizando $14,00 \mathrm{~m}^{2}$.

\subsection{6- 46 $^{\circ}$ Distrito Policial - Perus}

A carceragem do $46^{\circ}$ Distrito Policial possuía:

-1 "viúva", medindo 4,00m x 1,90m, totalizando 7,60 m².

-1 pátio interno, medindo $12,00 \mathrm{~m} \times 5,50 \mathrm{~m}$, totalizando $66,00 \mathrm{~m}^{2}$, descoberto, mas com uma tela de proteção feita de ferro, que permitia a entrada de luz.

-5 celas medindo 4,00m x 3,70m e contendo uma pequena copa e banheiro, totalizando $14,80 \mathrm{~m}^{2}$, cada uma.

-1 "corró" externo, medindo $5,00 \mathrm{~m}$ x $1,85 \mathrm{~m}$, com banheiro, totalizando $9,25 \mathrm{~m}^{2}$.

\subsection{7- 87 $^{\circ}$ Distrito Policial - Pereira Barreto}

A carceragem do $87^{\circ}$ Distrito Policial possuía:

-1 “viúva”, medindo 9,43m x 2,00m, totalizando $18,86 \mathrm{~m}^{2}$.

-2 pátios internos, separados por uma parede, medindo $7,50 \mathrm{~m} \times 2,20 \mathrm{~m}$, totalizando $16,50 \mathrm{~m}^{2}$ cada um. Os pátios eram cobertos com laje e não possuíam entrada de luz e ventilação.

-2 celas do lado direito, medindo $3,85 \mathrm{~m}$ x $2,10 \mathrm{~m}$ e contendo uma pequena copa e banheiro, totalizando $8,08 \mathrm{~m}^{2}$, cada uma.

-2 celas do lado esquerdo, medindo $5,73 \mathrm{~m}$ x 2,93m e contendo uma pequena copa e banheiro, totalizando $16,79 \mathrm{~m}^{2}$, cada uma.

-1 "corró" externo, medindo, aproximadamente, $2,00 \mathrm{~m}$ x 1,00m, totalizando $2,00 \mathrm{~m}^{2}$, e que estava desativado na época da pesquisa. 


\subsection{8- 89 ${ }^{\circ}$ Distrito Policial - Portal do Morumbi (Feminino)}

A carceragem do $89^{\circ}$ Distrito Policial possuía:

-1 "viúva", medindo 5,00m x 2,00m, totalizando $10,00 \mathrm{~m}^{2}$.

-2 pátios internos, separados por uma parede, medindo $8,00 \mathrm{~m} \times 2,50 \mathrm{~m}$, totalizando $20,00 \mathrm{~m}^{2}$, cada um. Os pátios eram cobertos com laje e não possuíam entrada de luz e ventilação.

-2 celas do lado direito, contendo banheiro e copa, medindo 4,00m x 2,50m, totalizando $11,25 \mathrm{~m}^{2}$, cada uma.

-2 celas do lado esquerdo, contendo banheiro e copa, medindo 4,50m x $4,00 \mathrm{~m}$, totalizando $18,00 \mathrm{~m}^{2}$, cada uma.

-1 “corró" externo, para presas juradas de morte, medindo 2,80m x 2,50m, com banheiro, totalizando $7,00 \mathrm{~m}^{2}$.

\subsection{9- $91^{\circ}$ Distrito Policial - Ceasa}

A carceragem do $91^{\circ}$ Distrito Policial possuía:

-1 "viúva", medindo 3,60m x 2,00m, totalizando 7,20 $\mathrm{m}^{2}$.

-1 pátio interno, medindo $16,80 \mathrm{~m}$ x $2,00 \mathrm{~m}$, totalizando $33,60 \mathrm{~m}^{2}$, descoberto, mas com uma tela de proteção feita de ferro, permitindo a entrada de luz.

-2 celas medindo 5,30m x 4,80m e contendo uma pequena copa e banheiro, totalizando $25,44 \mathrm{~m}^{2}$, cada uma.

-2 celas medindo 4,80m x 3,10m e contendo uma pequena copa e banheiro, totalizando $14,88 \mathrm{~m}^{2}$, cada uma.

-1 “corró" externo, medindo 4,30m x 1,70m, com banheiro, totalizando $7,31 \mathrm{~m}^{2}$.

\section{3- Levantamento dos Dados}

\subsection{1- Elaboração da estratégia}

Para a viabilização desta pesquisa, inicialmente foi realizada uma reunião com o Delegado Titular de Polícia da $3^{\text {a }}$ Delegacia Seccional de Polícia - Oeste da cidade de São Paulo, localizada no $2^{\circ}$ andar do prédio do $14^{\circ}$ Distrito Policial Pinheiros, durante a qual foram expostos o problema da tuberculose nas prisões e os objetivos deste estudo. 
Após a concordância e autorização do Delegado Titular para o desenvolvimento desta pesquisa, foi elaborado um cronograma das atividades que seriam desenvolvidas com a população carcerária dos Distritos Policiais.

O cronograma abrangeu as seguintes atividades: aplicação de um inquérito individual, aplicação e leitura da prova tuberculínica (PPD), coleta de amostras de escarro para o diagnóstico da tuberculose, além de uma consulta aos prontuários dos detentos.

Como eram 9 os Distritos Policiais da Zona Oeste da Cidade de São Paulo, determinou-se um intervalo de 45 dias para a visita de cada um, tendo em vista a necessidade de reuniões preparatórias com os Delegados, funcionários e detentos de cada Distrito Policial, e o tempo necessário para a realização dos exames no Laboratório de Micobactérias, do Departamento de Epidemiologia, da Faculdade de Saúde Pública da Universidade de São Paulo.

Em resposta ao cronograma, o Delegado Titular enviou um ofício à todos os Delegados dos Distritos Policiais, informando a data da visita ao local e os procedimentos que seriam realizados.

Gentilmente, o Delegado Titular disponibilizou uma viatura e 3 Investigadores da Polícia Civil para nos acompanhar durante todo o período da pesquisa.

$\mathrm{Na}$ semana anterior ao início das atividades em cada Distrito Policial, realizava-se uma reunião com o Delegado de Polícia local, os funcionários, os responsáveis pelos prontuários dos detentos, os carcereiros e, posteriormente, com os presos, para que todos se inteirassem da importância da busca de casos de tuberculose em presídios e dos procedimentos que seriam realizados, especialmente a maneira de se coletar o escarro, visando o maior número possível de adesões.

Após a anuência e concordância de todos os envolvidos, o Delegado local fornecia a grade dos presos, ou seja, uma relação com nome, filiação, delito cometido e número total de detentos encarcerados, existentes naquele dia, no Distrito Policial. A partir destas informações, preparava-se com bastante antecedência todo o material que seria utilizado na pesquisa.

Como este estudo envolveu seres humanos, de acordo com a Resolução 196/96, do Conselho Nacional de Saúde, foi elaborado um Termo de Consentimento 
Esclarecido, conforme modelo em anexo (Anexo 1), aprovado pelo Conselho de Ética da Faculdade de Saúde Pública da Universidade de São Paulo, que seria assinado pelos detentos que concordassem em participar da pesquisa.

\subsection{2- A estratégia}

Assim que as atividades eram iniciadas em um Distrito Policial, uma viatura da $3^{\text {a }}$ Delegacia Seccional de Polícia - Oeste, com 3 Investigadores da Polícia Civil, passava na Faculdade de Saúde Pública-USP, no período da manhã, e transportava os participantes da pesquisa até o Distrito pré-determinado no cronograma que havia sido entregue ao Delegado Titular da Seccional, permanecendo no local o tempo que fosse preciso, garantindo assim, a segurança dos profissionais da saúde.

No momento do acesso à carceragem, fazia-se uma chamada nominal dos detentos daquele local, e mediante a concordância e assinatura do "Termo de Consentimento Esclarecido", realizavam-se os seguintes procedimentos:

1- No primeiro dia (em uma $6^{\text {a }}$-feira), após a assinatura do "Termo de Consentimento Esclarecido" pelos detentos que aceitaram participar da pesquisa, profissionais aferidos pela Secretaria de Estado da Saúde e supervisionados por uma Enfermeira, aplicaram a prova tuberculínica (PPD-RT23 - 2UT/0,1ml) nos presos, enquanto outros profissionais auxiliaram na entrevista, por meio de um inquérito individual (Anexo 2), para posterior estudo das características daquela população carcerária.

2- Na $2^{\text {a }}$-feira (72 horas após a aplicação do PPD), foi realizada a leitura da prova tuberculínica, pelos mesmos profissionais aferidos pela Secretaria de Estado da Saúde, enquanto iniciou-se a coleta da $1^{\mathrm{a}}$ amostra de escarro, em um número prédeterminado de detentos. Este cálculo foi feito, dividindo-se o número de detentos do Distrito Policial pelos 5 dias úteis da semana. Assim, o número de amostras colhidas, diariamente, variou de 25 a 33, de acordo com o tamanho da população carcerária daquele local.

3- De $3^{\mathrm{a}}$ a $6^{\mathrm{a}}$-feira, continuou-se a coleta da $1^{\mathrm{a}}$ amostra de escarro dos detentos existentes naquele Distrito Policial, visando o diagnóstico da tuberculose.

4- Na semana seguinte, de $2^{\mathrm{a}}$ a $4^{\mathrm{a}}$-feira, coletou-se a $2^{\mathrm{a}}$ amostra de escarro dos presos que haviam sido reatores fortes ao PPD e/ou sintomáticos respiratórios. 
5- Nos dois últimos dias ( $5^{\mathrm{a}}$ e $6^{\mathrm{a}}$-feiras), consultou-se os prontuários de todos os detentos, para comparação com o inquérito aplicado individualmente, visando a veracidade ou não das respostas, além da busca de outras informações como a vida pregressa do detento, filiação, estado civil, escolaridade, profissão, endereço e, principalmente, o (s) Artigo (s) do Código Penal Brasileiro pelo qual haviam sido enquadrados.

Durante as 2 semanas de trabalho em cada Distrito Policial, as amostras de escarro colhidas dos detentos foram processadas no Laboratório de Micobactérias, do Departamento de Epidemiologia, da Faculdade de Saúde Pública-USP, por meio da realização da baciloscopia e cultura, visando o diagnóstico da tuberculose nos detentos, segundo normas padronizadas pelo Laboratório, de acordo com as recomendações do MINISTÉRIO DA SAÚDE ${ }^{45}$ 1994, em seu "Manual de bacteriologia da tuberculose".

As culturas de escarro que, após o período de incubação necessário, resultaram positivas, foram devidamente identificadas e enviadas ao Laboratório de Micobactérias do Instituto Adolfo Lutz da cidade de São Paulo, pertencente à Secretaria de Estado da Saúde, para a identificação das cepas de micobactérias e realização do teste de sensibilidade às drogas antituberculose, nas cepas identificadas como M. tuberculosis (para averiguação da resistência bacteriana).

Os doentes diagnosticados foram notificados e tratados pelas equipes de saúde da região à qual pertencia o Distrito Policial.

\subsection{3- Técnicas utilizadas}

\subsubsection{1- Inquérito individual}

O inquérito individual (Anexo 2), aplicado aos detentos dos Distritos Policiais da Zona Oeste da Cidade de São Paulo, continha duas partes. A primeira era o inquérito propriamente dito, com as seguintes informações:

- Número do Distrito Policial.

- Data da pesquisa.

- Nome do detento.

- Filiação.

- Idade. 
- Estado civil.

- Número de fillhos.

- Cor ou raça.

- Procedência: naturalidade e nacionalidade.

- Nível de instrução.

- Profissão.

- Tempo de permanência no Distrito Policial.

- Prisão anterior.

- Tempo de prisão anterior.

- Tuberculose anterior.

- Contato prévio com pessoas tuberculosas.

- Sintomas de tuberculose.

- Infecção pelo HIV.

A segunda parte era para uso do Laboratório e continha:

- Datas de aplicação e leitura da prova tuberculínica (PPD).

- Resultado da prova tuberculínica (PPD).

- Resultado da baciloscopia.

- Motivo para não realização da baciloscopia.

- Resultado da cultura.

- Motivo para não realização da cultura.

- Resultado da identificação das cepas

- Resultado do teste de sensibilidade às drogas antituberculose.

As informações complementares, necessárias para a pesquisa, foram obtidas nos prontuários dos detentos e anotadas no inquérito individualizado. Eram as seguintes:

- Confirmação da filiação do detento.

- Se estava empregado no momento da prisão.

- Renda mensal do detento que estava empregado.

- Endereço residencial do detento.

- Uso de álcool e drogas.

- Confirmação da infecção pelo HIV. 
- Delito atual cometido pelo detento, ou seja, o motivo pelo qual estava preso. Foram anotados até 5 delitos diferentes cometidos pelo mesmo preso, de acordo com sua gravidade.

- Se o detento estava cumprindo pena no Distrito Policial.

- Confirmação dos locais onde ficou preso anteriormente. Foram anotados até 4 locais diferentes pelos quais o detento havia passado.

- Delito anterior cometido pelo detento, ou seja, o motivo pelo qual havia sido preso anteriormente. Foram anotados até 3 delitos diferentes cometidos anteriormente pelo mesmo preso, considerando sua gravidade.

\section{- Material necessário para a entrevista, por meio de inquérito individual}

- Inquérito individual (Anexo 2) impresso e identificado com o nome do detento, e alguns não identificados para os presos recém-chegados ao Distrito Policial.

- Canetas.

- Pranchas de madeira para apoio do papel.

\subsubsection{2- Prova tuberculínica}

Utilizada como método auxiliar de diagnóstico da tuberculose e, quando positiva, indica infecção prévia pelo Mycobacterium tuberculosis, não permitindo distinguir o indivíduo infectado do doente. Em áreas onde a vacinação BCG é feita rotineiramente, sua interpretação pode ser prejudicada. Seu valor é maior em pessoas não vacinadas com BCG, ou naquelas vacinadas há longa data, já que a memória linfocitária diminui com o tempo ${ }^{47,49,71}$.

Segundo normas padronizadas pelo MINISTÉRIO DA SAÚDE ${ }^{46,47,49}$ 1994, 1995, 2002, a tuberculina usada na prova tuberculínica é o PPD-RT23, aplicada segundo técnica e material preconizados pela OMS, por via intradérmica no terço médio da face anterior do antebraço esquerdo, na dose de $0,1 \mathrm{ml}$, equivalente a 2 UT (unidades de tuberculina).

A leitura da prova tuberculínica é realizada 72 a 96 horas após a aplicação, medindo-se com régua milimetrada o maior diâmetro transverso da área de induração 
palpável. O resultado é registrado em milímetros, de acordo com a seguinte classificação:

- 0 a 4 mm - não reator - indivíduo não infectado pelo bacilo da tuberculose ou anérgico.

- 5 a 9 mm - reator fraco - indivíduo infectado pelo bacilo da tuberculose ou por outras micobactérias, ou vacinado com BCG.

- $10 \mathrm{~mm}$ e mais - reator forte - indivíduo infectado pelo bacilo da tuberculose, doente ou não, ou vacinado recente com $\mathrm{BCG}^{46,47,49}$.

\section{- Material necessário para aplicação e leitura da prova tuberculínica}

- Isopor/geladeira com frasco de PPD-RT23 $2 \mathrm{UT}$ (entre $+4^{\circ} \mathrm{C}$ e $+8^{\circ} \mathrm{C}$ e protegido da luz).

- Seringas descartáveis tipo tuberculina ( $1 \mathrm{ml}$ de capacidade).

- Agulhas hipodérmicas descartáveis 13 x 4,5 ou similares.

- Luva cirúrgica.

- Frasco com álcool.

- Recipiente com algodão.

- Caixa coletora para materiais pérfuro-cortantes.

- Régua milimetrada transparente de $10 \mathrm{~cm}$, para leitura da prova.

\subsubsection{3- Processamento das amostras de escarro}

O material biológico investigado neste estudo foi o escarro dos detentos encarcerados nos Distritos Policiais da Zona Oeste da Cidade de São Paulo, que colaboraram com a pesquisa, com ênfase nos sintomáticos respiratórios e reatores à prova tuberculínica. As amostras de escarro colhidas foram processadas no Laboratório de Micobactérias, segundo normas padronizadas pelo Laboratório, de acordo com as recomendações do MINISTÉRIO DA SAÚDE 45 1994, no "Manual de bacteriologia da tuberculose".

- Baciloscopia - Realizada pelos métodos de coloração fluorescente (Auramina) e Ziehl-Neelsen.

As amostras de escarros foram submetidas à confecção de esfregaços em lâminas de vidro lapidadas, com uma extremidade fosca, medindo 26x76mm e 
espessura 0,9 a 1,1mm, sendo fixadas e posteriormente coradas pelo Método Fluorescente (Auramina), para triagem. A leitura das mesmas foi efetuada em microscópio de fluorescência (Jenamed 2 - Carl Zeiss) e, quando positivas, o esfregaço foi corado novamente pela técnica de Ziehl-Neelsen e o resultado apresentado em cruzes.

- Cultura - A cultura foi realizada pelos métodos de descontaminação de Petroff e Ogawa-Kudoh (segundo técnica padronizada pelo Instituto Adolfo Lutz de São Paulo ${ }^{10}$ ), com posterior semeadura nos meios de Lowenstein-Jensen e OgawaKudoh.

A descontaminação dos escarros pelo Método de Petroff, consistiu na concentração das amostras por centrifugação após tratamento com $\mathrm{NaOH}$ a $4 \%$ contendo vermelho de fenol como indicador, acidificação com $\mathrm{HCl}$ a $4 \%$ e posterior neutralização até atingir $\mathrm{pH}=7$. Em seguida, com uma pipeta de vidro de $1 \mathrm{ml}$, foram semeadas quatro gotas do sedimento descontaminado de cada amostra, em dois tubos de meio de Lowenstein-Jensen e incubados a $37^{\circ} \mathrm{C}$ por um período de 30 a 60 dias, sendo o resultado apresentado em cruzes (quando positivo), de acordo com o número de colônias.

A descontaminação pelo método de Ogawa-Kudoh $^{10}$, consistiu na transferência de um swab (zaragatoa) estéril, impregnado com a porção mais purulenta do escarro, para um tubo de ensaio contendo $3 \mathrm{ml}$ de $\mathrm{NaOH}$ a $4 \%$, durante 2 minutos. Em seguida, foram semeados, com o próprio swab, dois tubos de meio de Ogawa Kudoh e incubados a $37^{\circ} \mathrm{C}$ por um período de 30 a 60 dias, sendo o resultado apresentado em cruzes (quando positivo), de acordo com o número de colônias.

\section{- Material necessário para a coleta de escarro}

- Pote plástico descartável, transparente, boca larga (50mm de diâmetro) e tampa de rosca, altura de $40 \mathrm{~mm}$ e com capacidade de 30 a $50 \mathrm{ml}$.

- Etiquetas para identificação dos potes.

- Caneta.

- Luva cirúrgica.

- Caixa térmica para transporte dos potes (contendo um suporte para evitar o derramamento do material biológico). 


\section{4- Análise dos Dados}

Com base nas informações obtidas no inquérito individual e após ajustes e correções de algumas variáveis durante a consulta aos prontuários dos presos, foi feita uma ficha de pré-codificação (Anexo 3), com o auxílio de um programador de computador, no Programa EPI-INFO, para digitação dos dados.

A ficha de pré-codificação apresentou as seguintes variáveis:

1- Número do EPI-INFO, com 4 caselas.

2- Número do inquérito, com 4 caselas.

3- Número do Distrito Policial, com 2 caselas.

4- Data da pesquisa, com 2 caselas para o dia, 2 para o mês e 2 para o ano.

5- Nome do detento, com 35 caselas.

6- Nome da mãe do detento, com 35 caselas.

7- Pai do detento, com 1 casela, codificado em:

1- Conhecido.

2- Conhecido e falecido.

3- Desconhecido.

9- Sem informação.

8- Sexo, com 1 casela, codificado em:

1- Masculino.

2- Feminino.

9- Idade em anos, com 2 caselas, sendo reservada a dezena 99 para "Ignorada".

10- Estado civil, com 1 casela, codificado em:

1- Solteiro.

2- Casado.

3- Separado.

4- Desquitado.

5- Divorciado.

6- Viúvo.

7- Amasiado.

9- Ignorado. 
Obs- A categoria "Amasiado" foi incluída, devido à grande quantidade de citações por parte dos detentos.

11- Se tem filhos, com 1 casela, codificado em:

1- Sim.

2- Não.

9- Ignorado.

Obs- Se a resposta for sim, passar para a questão 12. Se não, para a 13.

12- Quantos filhos, com 1 casela, codificado em:

1- 1 filho.

2- 2 filhos.

3- 3 filhos.

4- 4 filhos.

5- 5 filhos.

6- Mais que 5 filhos.

13- Cor ou raça, (segundo classificação utilizada pelo IBGE no Censo 2000, www.ibge.gov.br), com 1 casela, codificada em:

1- Branca.

2- Preta.

3- Parda.

4- Amarela.

5- Indígena.

6- Outra.

9- Ignorada.

14- Nacionalidade, (segundo classificação utilizada pelo IBGE no Censo 2000, www.ibge.gov.br), com 1 casela, codificada em:

1- Brasileiro nato.

2- Brasileiro naturalizado.

3- Estrangeiro.

9- Ignorada.

15- Cidade onde nasceu, com 1 casela, codificada em:

1- Capital de Estados Brasileiros.

2- Cidade grande. 
3- Cidade de porte médio.

4- Cidade pequena.

9- Sem informação.

Obs- Sendo considerada cidade grande, aquela com mais de 200 mil habitantes e que não era "Capital de Estados Brasileiros"; cidade de porte médio aquela com 50 a 200 mil habitantes; e cidade pequena, aquela com até 50 mil habitantes. (IBGE-2000 - www.ibge.gov.br Cidades@ - O Brasil Município por Município).

16- Estado onde nasceu, com 2 caselas, (utilizando-se a sigla do Estado, de acordo com o IBGE-2000 - www.ibge.gov.br - Cidades@-O Brasil Município por Município).

17- Nível de instrução (segundo classificação utilizada pelo IBGE no Censo 2000, www.ibge.gov.br), com 1 casela, codificado em:

1- Sem instrução.

2- $1^{\circ}$ grau incompleto.

3- $1^{\circ}$ grau completo.

4- $2^{\circ}$ grau incompleto.

5- $2^{\circ}$ grau completo.

6- Superior incompleto.

7- Superior completo.

9- Ignorado.

18- Profissão do detento (classificada de acordo com as profissões citadas pelos detentos durante o inquérito individual, e após a comparação com as informações contidas nos prontuários dos mesmos. Por ser uma questão aberta no inquérito, as profissões foram agrupadas pela freqüência de citação), com 30 caselas.

19- Se estava empregado no momento da prisão, com 1 casela, codificado em:

1- $\operatorname{Sim}$

2- Não

9- Ignorado.

Obs- Se a resposta for sim, passar para a questão 20. Se não, para a 21. 
20- Qual a renda do detento na época, com 1 casela, codificada em:

1- Menor que 1 salário mínimo.

2- De 1 a 2 salários mínimos.

3- Maior que 2 a 5 salários mínimos.

4- Maior que 5 a 10 salários mínimos.

5- Maior que 10 salários mínimos.

9- Ignorada.

Obs- Classificação de acordo com o salário mínimo vigente no Brasil, na época da pesquisa, sendo que em $1^{\circ}$ de maio de 1999 o salário mínimo era de $\mathrm{R} \$ 136,00$; em 03 de abril de 2000 de $\mathrm{R} \$ 151,00$ e em $1^{\circ}$ de abril de 2001 de $\mathrm{R} \$ 180,00$.

21- Endereço da residência do detento, com 5 caselas (segundo código proposto pelo Grupo Técnico Normativo de Auditoria e Controle GTNAC - da Secretaria de Estado da Saúde e utilizado pela mesma).

22- Uso de álcool, com 1 casela, codificado em:

1- Sim.

2- Não.

9- Ignorado.

23- Uso de maconha, com 1 casela, codificado em:

1- Sim.

2- Não.

9- Ignorado.

24- Uso de crack, com 1 casela, codificado em:

1- Sim.

2- Não.

9- Ignorado.

25- Uso de cocaína, com 1 casela, codificado em:

1- Sim.

2- Não.

9- Ignorado. 
26- Tempo de permanência neste Distrito Policial, com 4 caselas, em dias. (Considerou-se um ano=365 dias, um mês $=30$ dias e uma semana $=7$ dias).

27- Delito atual 1, como o delito cometido pelo detento, que era o motivo de sua atual prisão, classificado pelos Artigos do Código Penal Brasileiro, com 2 caselas e codificado em:

01- Homicídio.

02- Tentativa de homicídio.

03- Latrocínio (roubo seguido de morte).

04- Roubo.

05- Tentativa de roubo.

06- Furto.

07- Tentativa de furto.

08- Porte ilegal de arma.

09- Tráfico de drogas.

10- Porte de entorpecente.

11- Seqüestro e cárcere privado.

12- Estupro.

13- Tentativa de estupro.

14- Atentado violento ao pudor.

15- Estelionato.

16- Formação de quadrilha/bando.

17- Receptação dolosa.

18- Corrupção ativa.

19- Lesão corporal dolosa.

20- Corrupção de menores art. $1^{\circ}$.

21- Corrupção de menores art. 218.

22- Ameaça.

23- Extorsão.

24- Extorsão mediante seqüestro.

25- Falsificação de documento público.

26- Falsidade ideológica. 
27- Uso de documento falso.

28- Resistência à prisão.

29- Desacato.

30- Outros.

99- Ignorado.

28- Delito atual 2, caso o detento tenha cometido atualmente um segundo delito, com 2 caselas e mesma codificação da questão 27, acrescentando-se o código 31 para "Não cometeu outro delito atual".

29- Delito atual 3, caso o detento tenha cometido atualmente um terceiro delito, com 2 caselas e mesma codificação da questão 27, acrescentando-se o código 31 para "Não cometeu outro delito atual".

30- Delito atual 4, caso o detento tenha cometido atualmente um quarto delito, com 2 caselas e mesma codificação da questão 27, acrescentando-se o código 31 para "Não cometeu outro delito atual".

31- Delito atual 5, caso o detento tenha cometido atualmente um quinto delito, com 2 caselas e mesma codificação da questão 27, acrescentando-se o código 31 para "Não cometeu outro delito atual".

32- Se o detento estava cumprindo pena no Distrito Policial, com 1 casela, codificado em:

1- Sim.

2- Não.

9- Ignorado.

Obs: Já havia sido julgado e condenado e permanecia no Distrito.

33- Se já esteve preso antes, com 1 casela, codificado em:

1- Sim.

2- Não.

9- Ignorado.

Obs: Se a resposta for sim, passar para as questões 34 a 42. Se não, para a 43.

34- Quantas vezes foi preso, com 1 casela, codificado em:

1- 1 vez.

2- 2 vezes.

3- 3 vezes. 
4- 4 vezes.

5- 5 vezes.

6- Mais que 5 vezes.

9- Ignorado.

35- Por quanto tempo ficou preso, com 4 caselas, em dias. (Considerou-se um ano $=365$ dias, um mês $=30$ dias e uma semana $=7$ dias $)$

36- Local 1, como o primeiro local em que esteve detido anteriormente à atual prisão, com 1 casela, codificado em:

1- Febem.

2- Outros Distritos Policiais.

3- Casa de Detenção.

4- Penitenciária do Estado.

5- Centro de Detenção Provisória (CDP).

6- Interior de São Paulo.

7- Outros Estados.

9- Ignorado.

37- Local 2, como o segundo local em que esteve detido anteriormente, com 1 casela e mesma codificação da questão 29, acrescentando-se o código 8 para "Não ficou em outro local".

38- Local 3, como o terceiro local, com 1 casela e mesma codificação da questão 29, acrescentando-se o código 8 para "Não ficou em outro local".

39- Local 4, como o quarto local, com 1 casela e mesma codificação da questão 29, acrescentando-se o código 8 para a opção "Não ficou em outro local".

40- Delito anterior 1 , como o delito cometido pelo detento, anteriormente à atual prisão, com 2 caselas, e mesma codificação da questão 27, acrescentando-se o código 31 para "Não cometeu outro delito anterior".

41- Delito anterior 2, caso o preso tenha cometido um segundo delito anterior, com 2 caselas e mesma classificação da questão 27, acrescentando-se o código 31 para "Não cometeu outro delito anterior". 
42- Delito anterior 3, com 2 caselas caso o preso tenha cometido um terceiro delito anterior, com 2 caselas e mesma classificação da questão 27, acrescentando-se o código 31 para "Não cometeu outro delito anterior".

43- Se o detento já havia tido tuberculose, com 1 casela, codificado em:

1- Sim.

2- Não.

9- Ignorado.

Obs: se a resposta for sim, passar para as questões 44 a 46. Se não, para a 47.

44- Se recebeu tratamento, com 1 casela, codificado em:

1- Sim.

2- Não.

9- Ignorado.

45- Onde o detento recebeu o tratamento, com 1 casela, codificado em:

1- Na residência.

2- Centro de Saúde.

3- Hospital.

4- Presídio.

5- Outros.

9- Ignorado.

46- Tempo de tratamento, com 1 casela, codificado em:

1- Menos de 1 mês.

2- 1 mês.

3- 2 meses.

4- 3 meses.

5- 4 meses.

6- 5 meses.

7- 6 meses.

8- Mais que 6 meses.

9- Ignorado.

47- Se o detento já havia tido contato com alguma pessoa com tuberculose, com 1 casela, codificado em:

1- Sim. 
2- Não.

3- Ignorado.

Obs: Se a resposta for sim, passar para as questões 48 a 50. Se não, para a 51. 48- Onde foi o contato, com 1 casela, codificado em:

1- Na residência.

2- No trabalho.

3- No presídio.

4- Outros.

9- Ignorado.

49- Com quem teve contato, com 1 casela, codificado em:

1- Familiares.

2- Vizinhos.

3- Colegas de trabalho.

4- Detentos.

5- Outros.

9- Ignorado.

50- Tempo de contato, com 1 casela, codificado em:

1- Menor que 1 mês.

2- De 1 a 2 meses.

3- Maior que 2 a 4 meses.

4- Maior que 4 a 6 meses.

5- Maior que 6 a 12 meses.

6- Maior que 12 meses.

9- Ignorado.

51- Principal sintoma (Sintoma 1), com 1 casela, codificado em:

1- Sem sintomas.

2- Tosse com expectoração.

3- Febre.

4- Dor torácica.

5- Perda de peso.

6- Perda de apetite.

7- Hemoptise. 
8- Outros.

9- Ignorado.

52- Sintoma 2, com 1 casela, caso o preso tenha referido um segundo sintoma, com a mesma codificação da questão 51, acrescentando-se o código 0 para "Não tem outro sintoma".

53- Sintoma 3, com 1 casela, caso o preso tenha referido um terceiro sintoma, com a mesma codificação da questão 51, acrescentando-se o código 0 para "Não tem outro sintoma".

54- Sintoma 4, com 1 casela, caso o preso tenha referido um quarto sintoma, com a mesma codificação da questão 51, acrescentando-se o código 0 para "Não tem outro sintoma".

55- Sintoma 5, com 1 casela, caso o preso tenha referido um quinto sintoma, com a mesma codificação da questão 51, acrescentando-se o código 0 para "Não tem outro sintoma".

56- Tempo de sintomas, com 3 caselas, em dias, acrescentando-se os códigos:

000- Não tem sintomas.

999- Ignorado.

57- Se estava infectado pelo HIV, com 1 casela, codificado em:

1- Sim.

2- Não.

9- Ignorado.

58- Leitura da prova tuberculínica, com 1 casela, codificado em:

1- Não reator.

2- Reator fraco.

3- Reator forte.

4- Não fez a leitura.

9- Não realizada.

Obs: se for reator forte, passar para a questão 59. Se não, para a 60.

59- Reator forte com flictena ou necrose, com 1 casela, codificado em:

1- Sim.

2- Não. 
60- Número de amostras de escarro colhidas, com 1 casela, codificado em:

1- 1 amostra.

2- 2 amostras.

9- Não colheu.

Obs: Se não colheu, passar para a questão 61. Se colheu, para a 62.

61- Motivo para não colheita da amostra, com 1 casela, codificado em:

1- Não conseguiu.

2- Recusou.

3- Havia feito em outro Distrito Policial.

4- Alvará de soltura.

5- Foi transferido para outro Presídio.

6- Estava hospitalizado.

7- Estava no Fórum.

8- Outro.

9- Ignorado.

62- Resultado da baciloscopia, com 1 casela, codificado em:

1- Negativa.

2- Positiva + .

3- Positiva ++.

4- Positiva +++.

5- Não realizada.

63- Resultado da cultura, com 1 casela, codificado em:

1- Negativa.

2- Positiva + .

3- Positiva ++.

4- Positiva +++.

5- Contaminada.

6- Não realizada.

Obs: Se positiva a cultura, passar para as questões 64 e 65 .

64- Identificação da cepa isolada, com 1 casela, codificada em:

1-M. tuberculosis.

2- M. fortuitum. 
3- M. chelonae.

4- Complexo M. fortuitum/M. chelonae.

5- M. nonchromogenicum.

6- Micobactéria de crescimento rápido acromógena.

9- Outras.

65- Teste de sensibilidade às drogas antituberculose, das cepas identificadas como M. tuberculosis, com 1 casela, codificado em:

1- Sensível.

2- Resistente à INH e RMP.

3- Resistente à INH, RMP e PZA.

\section{5- Análise das Variáveis}

As variáveis analisadas foram as seguintes:

- Distritos Policiais.

- Número de detentos.

- Faixa etária.

- Estado civil.

- Cor ou raça.

- Local de nascimento.

- Nível de instrução.

- Renda mensal.

- Profissão.

- Local de residência.

- Delito atual cometido pelo detento.

- Tempo de permanência no Distrito Policial.

- Delito anterior cometido pelo detento.

- Tuberculose anterior.

- Sintomas.

- Tempo de sintomas.

- Prova tuberculínica (PPD).

- Baciloscopia.

- Cultura. 
- Identificação das cepas isoladas.

- Teste de sensibilidade às drogas antituberculose.

\subsection{1- Faixa etária}

As idades dos detentos, para uma melhor análise, e devido ao fato de todos os detentos serem maiores de 18 anos de idade, foram agrupadas nas seguintes faixas etárias:

- De 18 a 29 anos.

- De 30 a 39 anos.

- De 40 a 49 anos.

- De 50 a 59 anos.

- 60 anos e mais.

- Ignorada.

\subsection{2- Cor ou raça}

A cor ou raça do detento foi observada pelo entrevistador e anotada no inquérito individual. Posteriormente foi codificada, de acordo com a classificação utilizada pelo IBGE (Instituto Brasileiro de Geografia e Estatística), no Censo $2000^{30}$.

\subsection{3- Local de residência}

Quando o endereço do detento era informado em seu prontuário, anotava-se no inquérito individual. Se o endereço fosse da cidade de São Paulo, consultava-se guias e mapas da cidade, visando sua localização por bairros. Caso contrário, o endereço era classificado como pertencente à outras cidades ou outros Estados Brasileiros.

Para a codificação desta informação, foi utilizada a divisão territorial do Estado de São Paulo, segundo código proposto pelo Grupo Técnico Normativo de Auditoria e Controle - GTNAC - da Secretaria de Estado da Saúde e utilizado pela mesma, em:

- Cidade de São Paulo, dividida em 8 regiões: 
1- Região Centro, englobando os seguintes bairros: Sé, Liberdade, Cambuci, Aclimação, Barra Funda, Bom Retiro, Santa Cecília, Santa Efigênia, Consolação, Bela Vista, Pari, Mooca, Ibirapuera, Indianópolis, Vila Mariana, Cerqueira César, Jardim Paulista e Brás.

2- Região Butantã: Butantã, Lapa, Perdizes, Pinheiros, Vila Madalena e Jardim América.

3- Região Vila Prudente: Jabaquara, Saúde, Ipiranga, Vila Prudente e Sapopemba.

4- Região Penha: Tatuapé, Vila Formosa, Alto da Mooca, Vila Matilde, Penha de Franca, Belenzinho e Cangaíba.

5- Região Itaquera: Itaquera, Guaianases, São Miguel Paulista, Ermelino Matarazzo, Itaim Paulista e Cidade São Mateus.

6- Região Mandaqui: Santana, Vila Guilherme, Vila Maria e Tucuruvi.

7- Região Nossa Senhora do Ó: Perus, Vila Jaguara, Pirituba, Jaraguá, Brasilândia, Nossa Senhora do Ó, Vila Nova Cachoeirinha, Limão e Casa Verde.

8- Região Santo Amaro: Capela do Socorro, Parelheiros e Santo Amaro.

- Interior da Grande São Paulo (excluindo-se a cidade de São Paulo).

- Interior do Estado de São Paulo.

- Residente em outros Estados.

- Endereço não localizado.

- Sem residência fixa.

- Ignorado.

\subsection{4- Tempo de permanência}

O tempo de permanência nos Distritos Policiais, foi classificado em dias, com o seguinte intervalo de tempo:

$\bullet<60$ dias.

- 60 a 180 dias.

- 181 a 365 dias.

$\bullet 366$ dias. 
Para a comparação estatística entre tempo de permanência e resultado da prova tuberculínica dos detentos encarcerados nos Distritos Policiais da Zona Oeste da Cidade de São Paulo, foi realizado o "Teste de Tendência" no Programa EPIINFO 6.04 .

\subsection{5- Tempo de sintomas}

O tempo de sintomas de tuberculose, referidos pelos detentos sintomáticos, foi classificado em:

$\bullet<$ que 3 semanas

- 3 semanas a 2 meses

- > que 2 a 6 meses

- > que 6 meses a 1 ano

- > que 1 ano

\subsection{6- Prova tuberculínica}

Para algumas análises, foram considerados "não reatores" os detentos que apresentaram na leitura da prova tuberculínica uma induração palpável de 0 a 4 mm, e "reatores" os que apresentaram uma induração maior ou igual a $5 \mathrm{~mm}$.

\subsection{7- Baciloscopia}

A baciloscopia de escarro foi dividida em: Negativa, Positiva e Não realizada, sendo que a não realização do exame compreendeu os seguintes motivos:

- O detento não conseguiu colher a mostra.

- O detento se recusou a colher.

- Já havia feito em outro Distrito Policial.

- Recebeu alvará de soltura.

- Havia sido transferido para outro Presídio.

- Estava hospitalizado.

- Estava no Fórum.

- Outro motivo.

- Ignorado. 


\subsection{8- Cultura}

A cultura de escarro foi dividida em: Negativa, Positiva, Contaminada e Não realizada, sendo que a não realização do exame compreendeu os mesmos motivos citados na baciloscopia.

\subsection{9- Prevalência de detentos com tuberculose}

O cálculo da prevalência de tuberculose nos detentos dos Distritos Policiais da Zona Oeste da Cidade de São Paulo foi realizado dividindo-se o número de casos com baciloscopia e/ou cultura positivas, pela população carcerária estudada.

\section{6- Processamento dos Dados}

Os dados foram processados na base de dados EPI-INFO, analisados e representados em tabelas e gráficos. 


\section{4- RESULTADOS E DISCUSSÃO}

No período de março de 2000 a maio de 2001, avaliou-se a situação da tuberculose na população carcerária dos 9 Distritos Policiais da Zona Oeste da Cidade de São Paulo que, na época, eram os seguintes: $7^{\circ} \mathrm{DP}$ - Lapa, $14^{\circ} \mathrm{DP}$ Pinheiros, $33^{\circ}$ DP - Pirituba, $34^{\circ}$ DP - Morumbi, $37^{\circ}$ DP - Campo Limpo, $46^{\circ}$ DP Perus, $87^{\circ}$ DP - Pereira Barreto, $91^{\circ}$ DP - Ceasa e o $89^{\circ}$ DP - Portal do Morumbi que era o único feminino da região.

Segundo informações fornecidas pelos Delegados de Polícia de cada Distrito Policial, na semana anterior ao início da pesquisa, havia um total de 1.122 presos encarcerados nos 9 Distritos Policiais. Entretanto, no decorrer do trabalho este número sofreu alterações, pois 49 detentos obtiveram alvará de soltura, 38 foram transferidos para outro Presídio, 27 se recusaram a fazer os exames, 7 já haviam feito em outro Distrito Policial, 2 fugiram, 2 estavam hospitalizados e 55 novos detentos ingressaram nos Distritos.

Portanto, foram examinados 1.052 detentos nos 9 Distritos Policiais da Zona Oeste da Cidade de São Paulo, como demonstra a Tabela 1.

Nesta tabela, observa-se que foram examinados $93,8 \%$ do total de detentos informado pelos Delegados de Polícia dos 9 Distritos Policiais da Zona Oeste da Cidade de São Paulo.

A quantidade de presos libertados, transferidos, hospitalizados, fugitivos, ou que haviam feito o exame em outro DP, além dos novos ingressantes, denotam a extrema mobilidade desta população. 
Tabela 1 - Distribuição do número total e percentagem de detentos informado pelos Delegados de Polícia, em relação aos detentos examinados, nos Distritos Policiais da Zona Oeste da Cidade de São Paulo, 2000-2001.

\begin{tabular}{|c|c|c|c|c|}
\hline \multirow{2}{*}{$\begin{array}{c}\text { DISTRITOS POLICIAIS } \\
\text { (DP) }\end{array}$} & \multicolumn{2}{|c|}{ EXAMINADOS } & \multicolumn{2}{|c|}{ TOTAL INFORMADO } \\
\hline & $\mathbf{N}^{\mathbf{o}}$ & $\%$ & $\mathbf{N}^{\mathbf{o}}$ & $\%$ \\
\hline Lapa $-7^{\circ} \mathrm{DP}$ & 149 & 100,6 & 148 & 100,0 \\
\hline Pinheiros - $14^{\circ} \mathrm{DP}$ & 164 & 99,4 & 165 & 100,0 \\
\hline Pirituba $-33^{\circ} \mathrm{DP}$ & 167 & 94,4 & 177 & 100,0 \\
\hline Morumbi $-34^{\circ} \mathrm{DP}$ & 137 & 81,1 & 169 & 100,0 \\
\hline Campo Limpo $-37^{\circ} \mathrm{DP}$ & 163 & 95,3 & 171 & 100,0 \\
\hline Perus $-46^{\circ} \mathrm{DP}$ & 141 & 93,4 & 151 & 100,0 \\
\hline Pereira Barreto $-87^{\circ} \mathrm{DP}$ & 81 & 96,4 & 84 & 100,0 \\
\hline Portal do Morumbi $-89^{\circ} \mathrm{DP}$ & 3 & 42,9 & 7 & 100,0 \\
\hline Ceasa $-91^{\circ} \mathrm{DP}$ & 47 & 94,0 & 50 & 100,0 \\
\hline TOTAL & 1.052 & 93,8 & 1.122 & 100,0 \\
\hline
\end{tabular}

Do total de 1.052 detentos examinados, $1.049(99,7 \%)$ pertenciam ao sexo masculino e apenas $3(0,3 \%)$, eram do sexo feminino. O pequeno número de detentas analisadas deveu-se ao fato de que havia apenas um Distrito Policial feminino na Região Oeste da Cidade de São Paulo, e este Distrito abrigava somente 7 detentas, das quais, $4(57,1 \%)$ que possuíam nível universitário recusaram-se a participar da pesquisa.

Quanto à filiação dos 1.052 detentos, observou-se que 127 (12,1\%) eram filhos de pai desconhecido e $3(0,3 \%)$ eram órfãos de pai. Neste estudo, não foi possível fazer uma análise psicossocial do fato do pai do detento ser conhecido ou desconhecido e, portanto, se a ausência da figura paterna influenciou ou não sua conduta ao longo da vida. 
Do total de detentos, 557 (52,9\%) tinham filhos e $495(47,1 \%)$ declararam não ter filhos. Entre os 557 detentos que declararam ter filhos, $239(42,9 \%)$ tinham apenas 1 filho, $150(26,9 \%) 2$ filhos, 81 (14,5\%) 3 filhos, 43 (7,7\%) 4 filhos e 44 $(8,0 \%)$ tinham 5 ou mais filhos.

A faixa etária dos detentos está apresentada na Tabela 2:

Tabela 2 - Distribuição do número e percentagem dos detentos, segundo a faixa etária. Distritos Policiais da Zona Oeste da Cidade de São Paulo, 2000-2001.

\begin{tabular}{c|cc}
\hline FAIXA ETÁRIA* & $\mathbf{N}^{\mathbf{0}}$ & $\%$ \\
\hline De 18 a 29 anos & 750 & 71,3 \\
De 30 a 39 anos & 194 & 18,4 \\
De 40 a 49 anos & 76 & 7,2 \\
De 50 a 59 anos & 25 & 2,4 \\
60 anos e mais & 7 & 0,7 \\
Ignorada & - & - \\
\hline TOTAL & $\mathbf{1 . 0 5 2}$ & $\mathbf{1 0 0 , 0}$ \\
\hline
\end{tabular}

* Todos os detentos eram maiores de 18 anos de idade.

Nesta tabela, observa-se que os detentos encarcerados nos Distritos Policiais eram, em sua maioria, adultos jovens, sendo que 750 (71,3\%) tinham entre 18 e 29 anos, demonstrando a precocidade dos criminosos.

Fato este observado em diversos estudos, como o realizado no sistema prisional do Estado de Maryland, nos Estados Unidos da América ${ }^{68} 1990$, no qual 76\% dos 13.000 presos pertenciam à faixa etária de 18 a 35 anos, e também concordante com os dados consolidados pelo DEPEN (Departamento Penitenciário Nacional) ${ }^{44} \mathrm{em}$ 2002 , onde $61,7 \%$ dos detentos brasileiros tinham entre 18 e 30 anos de idade. 
De acordo com o ILANUD (Instituto Latino Americano das Nações Unidas para Prevenção do Delito) ${ }^{31}$ 1997, a maioria absoluta da população carcerária do Estado de São Paulo era composta por pessoas com até 30 anos de idade, refletindo a pirâmide etária da população em geral, com predomínio de jovens e diminuição gradativa com o avanço da idade, e refletindo também, em grande parte, as dificuldades encontradas pelos jovens no momento de sua inserção no mercado de trabalho ou de alguma outra forma de inserção social.

A comparação entre o estado civil e a faixa etária dos detentos, está apresentada na Tabela 3:

Tabela 3- Distribuição do número e percentagem dos detentos, segundo o estado civil e a faixa etária. Distritos Policiais da Zona Oeste da Cidade de São Paulo, 2000-2001.

\begin{tabular}{|c|c|c|c|c|c|c|c|c|c|c|c|c|}
\hline \multirow{3}{*}{$\begin{array}{c}\text { ESTADO } \\
\text { CIVIL }\end{array}$} & \multicolumn{10}{|c|}{ FAIXA ETÁRIA } & \multirow{2}{*}{\multicolumn{2}{|c|}{ TOTAL }} \\
\hline & \multicolumn{2}{|c|}{18 a 29} & \multicolumn{2}{|c|}{30 a 39} & \multicolumn{2}{|c|}{40 a 49} & \multicolumn{2}{|c|}{50 a 59} & \multicolumn{2}{|c|}{$60 \mathrm{e}+$} & TC & \\
\hline & $n^{0}$ & $\%$ & $\mathrm{n}^{\mathbf{0}}$ & $\%$ & $\mathbf{n}^{\mathbf{o}}$ & $\%$ & $n^{0}$ & $\%$ & $\mathbf{n}^{\mathbf{0}}$ & $\%$ & & \\
\hline Solteiro & 500 & 66,7 & 86 & 44,3 & 28 & 36,8 & 7 & 28,0 & 1 & 14,3 & 622 & 100,0 \\
\hline Casado & 51 & 6,8 & 53 & 27,3 & 31 & 40,9 & 16 & 64,0 & 5 & 71,4 & 156 & 100,0 \\
\hline Separado & 1 & 0,1 & 7 & 3,6 & 2 & 2,6 & - & - & - & - & 10 & 100,0 \\
\hline Desquitado & 2 & 0,3 & 4 & 2,1 & 4 & 5,3 & 1 & 4,0 & 1 & 14,3 & 12 & 100,0 \\
\hline Divorciado & - & - & - & - & 2 & 2,6 & - & - & - & - & 2 & 100,0 \\
\hline Viúvo & - & - & 3 & 1,6 & 2 & 2,6 & - & - & - & - & 5 & 100,0 \\
\hline Amasiado & 196 & 26,1 & 41 & 21,1 & 7 & 9,2 & 1 & 4,0 & - & - & 245 & 100,0 \\
\hline TOTAL & 750 & 71,3 & 194 & 18,4 & 76 & 7,2 & 25 & 2,4 & 7 & $\overline{0,7}$ & 1.052 & 100,0 \\
\hline
\end{tabular}

Em relação ao estado civil, do total de 1.052 detentos, $622(59,1 \%)$ eram solteiros, 245 (23,3\%) amasiados e $156(14,8 \%)$ casados. Os separados, desquitados, divorciados e viúvos, totalizaram 29 (2,8\%). Estes dados são concordantes com os informados pelo $\operatorname{DEPEN}^{44} 2002$, nos quais a população carcerária brasileira era constituída por $49,8 \%$ de detentos solteiros, $29,9 \%$ amasiados e $14,7 \%$ casados. 
Entretanto, se considerarmos que "amasiado" não é um estado civil, podendo, portanto, ser classificado como solteiro, a percentagem de solteiros na população carcerária dos Distritos Policiais sobe para 82,4\%, com 867 detentos apresentando este estado civil.

NIERO $^{52}$ 1981, observou nos 2 grupos de detentos estudados na Casa de Detenção de São Paulo, no período de 1976-1980, a predominância de solteiros, com uma percentagem de $74,0 \%$ no grupo 1 e $67,8 \%$ no grupo 2 .

Comparando-se o estado civil com a faixa etária dos detentos, observou-se que 500 detentos $(66,7 \%)$ eram solteiros e pertenciam à faixa etária de 18 a 29 anos de idade. Como a população carcerária dos Distritos Policiais era constituída, predominantemente, por jovens, uma maior proporção de solteiros entre eles, era esperada.

Outro dado que chamou a atenção, foi que entre os 245 detentos "amasiados", $196(80,0 \%)$ eram jovens na faixa etária de 18 a 29 anos, demonstrando que os presos mais jovens, raramente legalizavam sua situação conjugal; fato este observado entre os 156 detentos casados legalmente, dos quais apenas $51(32,7 \%)$ pertenciam à esta faixa etária.

Considerando-se, também nesta análise, que "amasiado" não é um estado civil, o número de detentos solteiros na faixa etária de 18 a 29 anos sobe para 696 e a percentagem, para $92,8 \%$.

A Tabela 4 apresenta a cor ou raça dos detentos, segundo classificação utilizada pelo IBGE, no Censo $2000^{30}$. Como a cor ou raça do detento foi observada pelo entrevistador, foram excluídas desta análise as classificações "Outra" e "Ignorada". 
Tabela 4 - Distribuição do número e percentagem dos detentos, segundo a cor ou raça. Distritos Policiais da Zona Oeste da Cidade de São Paulo, 2000-2001.

\begin{tabular}{c|cc}
\hline COR OU RAÇA & $\mathbf{N}^{\mathbf{0}}$ & $\boldsymbol{\%}$ \\
\hline Branca & 508 & 48,3 \\
Preta & 164 & 15,6 \\
Parda & 377 & 35,8 \\
Amarela & 2 & 0,2 \\
Indígena & 1 & 0,1 \\
\hline TOTAL & $\mathbf{1 . 0 5 2}$ & $\mathbf{1 0 0 , 0}$ \\
\hline
\end{tabular}

Observa-se nesta tabela, que 48,3\% dos detentos pertenciam à cor ou raça branca, $15,6 \%$ à cor ou raça negra e 35,8\% eram pardos, estando em concordância com os dados apresentados pelo $\operatorname{DEPEN}^{44} 2002$, nos quais $49,1 \%$ da população carcerária brasileira eram de etnia branca, $13,7 \%$ de etnia negra e $37,1 \%$ de etnia parda.

NIERO $^{52}$ 1981, encontrou na população carcerária da Casa de Detenção de São Paulo, $53,7 \%$ de detentos brancos e $46,5 \%$ de não brancos.

Segundo o MINISTÉRIO DA JUSTIÇA ${ }^{42}$ 1998, no "Censo Penitenciário de 1997”, a composição da população carcerária brasileira, em relação à cor ou raça, era de $48,0 \%$ de brancos, $17,0 \%$ de negros e $30,0 \%$ de pardos.

A população brasileira em 2000, de acordo com o IBGE, Censo Demográfico $2000^{30}$, era constituída por 169.872.856 habitantes. A composição desta população, em relação à cor ou raça, era de $53,7 \%$ brancos, $6,2 \%$ pretos, $38,5 \%$ pardos, $0,5 \%$ amarelos, 0,4\% indígenas e 0,7\% sem informação.

A análise da população carcerária do Estado de São Paulo, segundo a cor ou raça dos detentos, de acordo com o ILANUD ${ }^{31}$ 1997, "sugere um padrão estável no 
tempo, onde os brancos são o grupo predominante, seguidos pelos pardos e pretos. Esta constatação, não corrobora com a impressão popular de que os pretos e pardos compõem a maior parte dos criminosos. Esta associação entre cor e criminalidade, parece ser o fruto de uma imagem negativa dos não brancos, construída socialmente e reforçada pelos meios de comunicação".

Quanto à nacionalidade dos detentos, do total de 1.052 presos analisados neste estudo, apenas 2 eram estrangeiros e 1.050 eram brasileiros natos. A Tabela 5 mostra o local de nascimento (cidade natal) dos detentos.

Tabela 5 - Distribuição do número e percentagem dos detentos, segundo o local de nascimento. Distritos Policiais da Zona Oeste da Cidade de São Paulo, 2000-2001.

\begin{tabular}{c|rr}
\hline LOCAL DE NASCIMENTO & $\mathbf{N}^{\mathbf{0}}$ & $\boldsymbol{\%}$ \\
\hline Outro País & 2 & 0,2 \\
Capital de Estados Brasileiros & 552 & 52,5 \\
Cidade grande & 124 & 11,8 \\
Cidade de porte médio & 142 & 13,5 \\
Cidade pequena & 221 & 21,0 \\
Sem informação & 11 & 1,0 \\
\hline TOTAL & $\mathbf{1 . 0 5 2}$ & $\mathbf{1 0 0 , 0}$ \\
\hline
\end{tabular}

Quanto ao local de nascimento, 552 detentos haviam nascido em capitais de Estados Brasileiros. Destes, 499 (90,4\%) nasceram na capital do Estado de São Paulo e $53(9,6 \%)$ em capitais de outros Estados.

Comparando-se a localização das cidades de nascimento dos detentos com os Estados Brasileiros, observou-se que, das 124 cidades de grande porte, 99 (79,8\%) localizavam-se no Estado de São Paulo e 25 (20,2\%) em outros Estados. Das 142 cidades de médio porte, 61 (43,0\%) pertenciam ao Estado de São Paulo e 81 (57,0\%) 
à outros Estados. Das 221 cidades de pequeno porte, 24 (10,9\%) localizavam-se no Estado de São Paulo e 197 (89,1\%) em outros Estados.

Finalmente, as 11 cidades que não foram informadas, localizavam-se em outros Estados Brasileiros.

Contrariando as expectativas preconceituosas de que a maioria dos marginais da cidade de São Paulo é nordestina, do total de 1.050 (99,8\%) detentos brasileiros natos, 735 (70,0\%) haviam nascido na Região Sudeste do Brasil, e destes 683 $(92,9 \%)$ no Estado de São Paulo. Observou-se também, que dos 1.050 brasileiros natos, $33(3,1 \%)$ nasceram na Região Sul; $11(1,1 \%)$ na Região Centro-Oeste; 4 $(0,4 \%)$ na Região Norte, e 267 detentos, ou seja, 25,4\% do total, eram provenientes da Região Nordeste.

Em relação ao nível de instrução, segundo classificação utilizada pelo IBGE no Censo 2000 (Tabela 6), observou-se que a maioria dos detentos, 64,5\%, não havia completado o $1^{\circ}$ grau escolar.

Tabela 6 - Distribuição do número e percentagem dos detentos, segundo o nível de instrução. Distritos Policiais da Zona Oeste da Cidade de São Paulo, 2000-2001.

\begin{tabular}{c|rc}
\hline NÍVEL DE INSTRUÇÃo & $\mathbf{N}^{\mathbf{0}}$ & $\%$ \\
\hline Sem instrução & 43 & 4,1 \\
$1^{\text {o }}$ grau incompleto & 679 & 64,5 \\
$1^{\mathbf{o}}$ grau completo & 211 & 20,0 \\
$2^{\mathbf{o}}$ grau incompleto & 70 & 6,7 \\
$2^{\mathbf{o}}$ grau completo & 43 & 4,1 \\
Superior incompleto & 3 & 0,3 \\
Superior completo & 2 & 0,2 \\
Ignorado & 1 & 0,1 \\
\hline TOTAL & $\mathbf{1 . 0 5 2}$ & $\mathbf{1 0 0 , 0}$ \\
\hline
\end{tabular}


Quanto ao nível de instrução, a população carcerária brasileira, de acordo com o DEPEN ${ }^{44}$ 2002, tem a seguinte formação: 6,0\% de detentos analfabetos; $66,0 \%$ que não concluíram o $1^{\circ}$ grau; $15,1 \%$ com $1^{\circ}$ grau completo; $6,7 \%$ que não concluíram o $2^{\circ}$ grau; $5,6 \%$ com $2^{\circ}$ grau completo, e $0,7 \%$ com instrução superior. A composição da população carcerária dos Distritos Policiais estudados, em relação ao nível de instrução, segue a mesma distribuição da população carcerária brasileira, na qual a maioria dos detentos não concluiu o $1^{\circ}$ grau.

Segundo o ILANUD ${ }^{31}$ 1997, se por um lado a sociedade está enganada quando imagina que nas prisões só existem negros e nordestinos, a noção de que a cadeia é só para os mais pobres parece encontrar respaldo na realidade. Os dados demonstram que a criminalidade não é um comportamento típico dos totalmente excluídos, como analfabetos e miseráveis, mas daqueles que tiveram um grau mínimo de instrução.

Nesta população, a privação relativa, fator criminológico freqüentemente mais importante do que a privação absoluta, seria um elemento importante na indução ao comportamento criminoso ${ }^{31}$. Este fato foi observado nos detentos dos Distritos Policiais, uma vez que 64,5\% deles não haviam concluído o $1^{\circ}$ grau escolar.

Considerando que, em um país como o nosso, as desigualdades sociais são cumulativas, educação e renda estão associadas, pois a maioria dos detentos não possui a educação necessária para sua inserção no mercado de trabalho. Esta predominância dos pouco escolarizados nos presídios, tem se mantido constante desde a década de $50^{31}$.

Portanto, a baixa escolaridade observada, pode ter contribuído para a alta taxa de desemprego entre os detentos, pois, dos 1.052 presos, 486 (46,2\%) estavam desempregados no momento da prisão. A taxa de desemprego na população carcerária brasileira em 2002 era de $32,0 \%{ }^{44}$, e da população carcerária do Estado de São Paulo em 1996, de 42,0\% ${ }^{31}$.

Em relação à renda mensal, constatou-se que dos 1.052 detentos, apenas 566 $(53,8 \%)$ tinham renda, sendo que $563(99,5 \%)$ estavam empregados no momento da prisão e $3(0,5 \%)$ recebiam aposentadoria. 
A Tabela 7 mostra a renda mensal dos detentos assalariados, ou seja, dos detentos que estavam empregados e daqueles que recebiam aposentadoria.

Tabela 7 - Distribuição do número e percentagem dos detentos assalariados, segundo a renda mensal. Distritos Policiais da Zona Oeste da Cidade de São Paulo, 2000-2001.

\begin{tabular}{c|cc}
\hline RENDA MENSAL & $\mathbf{N}^{\mathbf{0}}$ & $\mathbf{\%}$ \\
\hline < que 1 salário mínimo & 12 & 2,1 \\
> que 1 a 2 salários mínimos & 83 & 14,7 \\
> que 2 a 5 salários mínimos & 104 & 18,4 \\
> que 5 a 10 salários mínimos & 27 & 4,8 \\
> que 10 salários mínimos & 6 & 1,0 \\
Ignorada & 334 & 59,0 \\
\hline TOTAL & $\mathbf{5 6 6}$ & $\mathbf{1 0 0 , 0}$ \\
\hline
\end{tabular}

Uma vez que, dos 566 detentos assalariados, 334 (59,0\%) não informaram a renda, pode-se constatar como esta variável foi difícil de ser obtida, pois os presos não queriam comentários financeiros na frente de outros detentos, além de não fornecerem esta informação aos Policiais no momento da prisão, para que a renda não constasse no prontuário, ao qual os Advogados teriam acesso. Entretanto, acreditamos que o real motivo, era porque fizeram do crime a sua profissão.

Em relação à profissão, dos 1.052 detentos, 190 (18,1\%) não tinham profissão definida, mas os outros $862(81,9 \%)$ informaram alguma atividade, confirmada pelos prontuários, cuja distribuição encontra-se na Tabela 8. 
Tabela 8 - Distribuição do número e percentagem dos detentos, segundo a profissão. Distritos Policiais da Zona Oeste da Cidade de São Paulo, 2000-2001.

\begin{tabular}{|c|c|c|}
\hline PROFISSÃO & $\mathbf{N}^{\mathbf{o}}$ & $\%$ \\
\hline Ajudante, auxiliar geral & 237 & 22,5 \\
\hline Artesão, tapeceiro, tecelão & 12 & 1,1 \\
\hline Autônomo & 23 & 2,2 \\
\hline Auxiliar de enfermagem & 03 & 0,3 \\
\hline Auxiliar de escritório & 15 & 1,4 \\
\hline Balconista & 14 & 1,3 \\
\hline Borracheiro & 14 & 1,3 \\
\hline Cabeleireiro & 07 & 0,7 \\
\hline Carpinteiro, marceneiro & 19 & 1,8 \\
\hline Carregador, embalador, montador & 24 & 2,3 \\
\hline Cobrador de ônibus, lotação & 07 & 0,7 \\
\hline Comerciante & 25 & 2,4 \\
\hline Cozinheiro, chapeiro, pizzaiolo & 09 & 0,9 \\
\hline Eletricista & 14 & 1,3 \\
\hline Encanador & 03 & 0,3 \\
\hline Estudante & 24 & 2,3 \\
\hline Feirante & 19 & 1,8 \\
\hline Garçom & 03 & 0,3 \\
\hline Gráfico & 10 & 1,0 \\
\hline Mecânico & 44 & 4,2 \\
\hline Metalúrgico & 14 & 1,3 \\
\hline Motoboy & 18 & 1,7 \\
\hline Motorista & 49 & 4,6 \\
\hline Office-boy & 22 & 2,1 \\
\hline Padeiro, confeiteiro & 03 & 0,3 \\
\hline Pedreiro & 49 & 4,6 \\
\hline Pintor de veículos & 44 & 4,2 \\
\hline Porteiro & 05 & 0,5 \\
\hline Segurança, vigia & 16 & 1,5 \\
\hline Vendedor ambulante & 42 & 4,0 \\
\hline Aposentado & 03 & 0,3 \\
\hline Sem profissão & 190 & 18,1 \\
\hline Outra profissão & 70 & 6,6 \\
\hline Profissão ignorada & 01 & 0,1 \\
\hline TOTAL & 1.052 & 100,0 \\
\hline
\end{tabular}


De acordo com esta tabela, a profissão mais freqüente entre os detentos, foi a de "ajudante, auxiliar geral" (237 - 22,5\%), que indica mão-de-obra não especializada; possível consequiência da baixa escolaridade, que gera falta de qualificação para um emprego melhor.

Outro dado que chamou a atenção, foi a quantidade de detentos "sem profissão" (190 - 18,1\%), já que grande parte dos presos afirmou "orgulhosamente", durante o inquérito individual, que a profissão exercida por eles era "ladrão ou traficante".

Entre os 1.052 detentos, 7 surpreenderam pela profissão que exerciam antes da prisão: 1 era bancário, 1 diretor de empresa, 1 engenheiro eletrônico, 1 funcionário público de alto escalão, 2 gerentes de empresas e 1 industrial, sendo que 6 deles tinham uma renda superior a 10 salários mínimos.

A Tabela 9 apresenta o local de residência do detento: 
Tabela 9 - Distribuição do número e percentagem dos detentos, segundo o local de residência. Distritos Policiais da Zona Oeste da Cidade de São Paulo, 2000-2001.

\begin{tabular}{c|cc}
\hline LOCAL DE RESIDÊNCIA & $\mathbf{N}^{\mathbf{o}}$ & $\mathbf{\%}$ \\
\hline Cidade de São Paulo: & 642 & 61,0 \\
1- Região Centro & 42 & 6,5 \\
2- Região Butantãa & 93 & 14,5 \\
3- Região Vila Prudente & 41 & 6,4 \\
4- Região Penha & 14 & 2,2 \\
5- Região Itaquera & 54 & 8,4 \\
6- Região Mandaqui & 14 & 2,2 \\
7- Região Nossa Senhora do Ó & 278 & 43,3 \\
8- Região Santo Amaro & 106 & 16,5 \\
Interior da Grande São Paulo & 254 & 24,1 \\
Interior do Estado de São Paulo & 25 & 2,4 \\
Outros Estados & 4 & 0,4 \\
Endereço não localizado & 27 & 2,6 \\
Sem residência fixa & 35 & 3,3 \\
Ignorado & 65 & $\mathbf{1 0 0 , 0}$ \\
\hline TOTAL & $\mathbf{1 . 0 5 2}$ &
\end{tabular}

Do total de detentos, 642 (61,0\%) residiam na cidade de São Paulo, sendo que $278(43,3 \%)$ destes eram provenientes da periferia da região Nossa Senhora do Ó. Esta região abrange os bairros de Perus, Vila Jaguara, Pirituba, Jaraguá, Brasilândia, Nossa Senhora do Ó, Vila Nova Cachoeirinha, Limão e Casa Verde, que em sua maioria, são bairros pobres e de periferia, confirmando que a criminalidade está, em grande parte, relacionada ao nível sócio-econômico dos detentos. 
Observou-se, que as 3 regiões com maior número de detentos residentes (Nossa Senhora do Ó, Santo Amaro e Butantã), foram aquelas nas proximidades de Distritos Policiais; sinalizando que, provavelmente, os detentos permaneçam encarcerados em Distritos próximos à sua residência.

Nesta classificação, utilizamos o código "Endereço não localizado", para aqueles endereços que, apesar de estarem anotados no prontuário do detento, não foi possível sua localização por bairro ou regiões, após extensas buscas em guias e mapas da cidade de São Paulo.

"Sem residência fixa", foi a classificação para moradores de rua, albergados e para a anotação no prontuário de que o detento realmente não tinha residência fixa.

A codificação "ignorado" foi utilizada quando não havia a informação do endereço do detento em seu prontuário.

Em relação ao uso de álcool e drogas, do total de 1.052 presos, $101(9,6 \%)$ mencionaram o uso de álcool, $86(8,2 \%)$ o uso de maconha, $71(6,7 \%)$ o uso de crack e $62(5,9 \%)$ o uso de cocaína.

Este tipo de informação também foi muito difícil de ser obtida. Geralmente os presos não gostam de comentar este e outros assuntos com estranhos, durante a aplicação de um questionário. Raras vezes o prontuário continha estas informações.

Quanto às características criminais dos detentos encarcerados nos Distritos Policiais da Zona Oeste da Cidade de São Paulo, observou-se que em todos os Distritos havia detentos primários (estavam presos pela primeira vez) e reincidentes (já haviam sido presos anteriormente).

O tempo de permanência dos detentos primários e reincidentes nos Distritos Policiais estudados está apresentado na Tabela 10. 
Tabela 10 - Distribuição do número e percentagem dos detentos primários e reincidentes, segundo o tempo de permanências nos Distritos Policiais da Zona Oeste da Cidade de São Paulo, 2000-2001.

\begin{tabular}{c|cccc|cc}
\hline TEMPO DE & \multicolumn{4}{|c|}{} & \multicolumn{2}{c}{} \\
PERMANÊNCIA & \multicolumn{2}{|c}{ PRIMÁRIOS } & \multicolumn{2}{c}{ REINCIDENTES } & \multicolumn{2}{c}{ TOTAL } \\
(EM DIAS) & $\mathbf{N}^{\mathbf{0}}$ & $\mathbf{\%}$ & $\mathbf{N}^{\mathbf{0}}$ & $\boldsymbol{\%}$ & $\mathbf{N}^{\mathbf{0}}$ & $\mathbf{\%}$ \\
\hline$<60$ & 162 & 47,0 & 183 & 53,0 & $\mathbf{3 4 5}$ & $\mathbf{1 0 0 , 0}$ \\
60 a 180 & 193 & 51,6 & 181 & 48,4 & $\mathbf{3 7 4}$ & $\mathbf{1 0 0 , 0}$ \\
181 a 365 & 143 & 57,0 & 108 & 43,0 & $\mathbf{2 5 1}$ & $\mathbf{1 0 0 , 0}$ \\
$>366$ & 55 & 67,1 & 27 & 32,9 & $\mathbf{8 2}$ & $\mathbf{1 0 0 , 0}$ \\
\hline TOTAL & $\mathbf{5 5 3}$ & $\mathbf{5 2 , 6}$ & $\mathbf{4 9 9}$ & $\mathbf{4 7 , 4}$ & $\mathbf{1 . 0 5 2}$ & $\mathbf{1 0 0 , 0}$ \\
\hline
\end{tabular}

Dos 1.052 detentos analisados, $553(52,6 \%)$ eram primários e $499(47,4 \%)$ eram reincidentes, ou seja, os reincidentes representavam quase a metade da população carcerária dos Distritos Policiais da Zona Oeste da Cidade de São Paulo.

NIERO $^{52}$ 1981, observou que na população carcerária da Casa de Detenção de São Paulo, havia uma predominância de detentos primários nos 2 grupos de presos estudados, sendo que 53,5\% dos detentos do grupo 1 e 66,3\% do grupo 2, estavam presos pela primeira vez.

De acordo com o ILANUD $^{31}$ 1997, a ressocialização do preso é um dos objetivos principais do sistema carcerário, para que este, cumprida a pena, possa retornar ao convívio social sem riscos para a comunidade e para ele próprio.

Entretanto, as taxas de reincidência encontradas na população carcerária revelam que o sistema não vem conseguindo cumprir sua função pois, desde os anos 80, é cada vez maior o número de ex-presidiários entre os presos. Se nos anos 50, cerca de $70 \%$ da população carcerária era constituída por presos primários, atualmente esta percentagem caiu para pouco mais da metade, consequiência, entre outros fatores, da deterioração física e humana do sistema carcerário no tempo ${ }^{31}$. 
O que chamou a atenção foi que presos realmente cumprem penas nos Distritos Policiais, pois do total de 1.052 detentos estudados, $727(69,1 \%)$ estavam aguardando julgamento e 325 (30,9\%) estavam cumprindo pena no Distrito Policial, ou seja, já haviam sido julgados e condenados e não haviam sido encaminhados à Penitenciárias do Estado ou à outro local mais adequado.

Entre os 76 detentos com permanência superior a 1 ano nestes locais, 3 detentos primários e 2 detentos reincidentes, permaneciam no Distrito Policial há quase 3 anos, e 1 preso reincidente já cumpria pena há 9 anos no mesmo Distrito.

A Lei de Execução Penal inclui orientações detalhadas, determinando que os presos sejam classificados e separados por sexo, antecedentes criminais, status legal (condenados ou aguardando julgamento) e outras características, reproduzindo os padrões internacionais sobre este assunto. Na prática, contudo, poucas destas regras são respeitadas, principalmente no que diz respeito à separação das diferentes categorias de presos, pois reincidentes violentos e pessoas presas pela primeira vez por ofensas menores, normalmente dividem a mesma cela no Brasil ${ }^{29}$. Fato este, também constatado nesta pesquisa.

De acordo com o MINISTÉRIO DA JUSTIÇA ${ }^{42}$ 1998, no “Censo Penitenciário de 1997”, por estes e outros motivos, as celas dos Distritos Policiais estão, em praticamente todos os Estados, superlotadas, com presos amontoados, em total desrespeito às mínimas condições de dignidade humana e à Lei de Execução Penal.

Esta aglomeração humana causa a corrupção, alimenta a promiscuidade e inflama as rebeliões. Além disso, a convivência entre condenados e provisórios, transforma as prisões em verdadeiras escolas do crime ${ }^{59}$.

Uma informação muito importante é o motivo pelo qual estavam presos, ou seja, os principais delitos cometidos pelos detentos, de acordo com o Código Penal Brasileiro, para se ter uma noção da periculosidade da população carcerária dos Distritos Policiais. Esta informação encontra-se na Tabela 11: 
Tabela 11 - Distribuição do número e percentagem dos detentos primários e reincidentes, segundo o delito atual. Distritos Policiais da Zona Oeste da Cidade de São Paulo, 2000-2001.

\begin{tabular}{|c|c|c|c|c|c|c|}
\hline \multirow{2}{*}{ DELITO COMETIDO } & \multicolumn{2}{|c|}{ PRIMÁRIOS } & \multicolumn{2}{|c|}{ REINCIDENTES } & \multicolumn{2}{|c|}{ TOTAL } \\
\hline & $\mathbf{N}^{\mathbf{o}}$ & $\%$ & $\mathbf{N}^{\mathbf{o}}$ & $\%$ & $\mathbf{N}^{\mathbf{o}}$ & $\%$ \\
\hline Homicídio & 25 & 4,5 & 29 & 5,8 & 54 & 5,1 \\
\hline Tentativa de homicídio & 20 & 3,6 & 11 & 2,2 & 31 & 2,9 \\
\hline Latrocínio & 1 & 0,2 & 1 & 0,2 & 2 & 0,2 \\
\hline Roubo & 235 & 42,5 & 186 & 37,3 & 421 & 40,0 \\
\hline Tentativa de roubo & 53 & 9,6 & 35 & 7,0 & 88 & 8,4 \\
\hline Furto & 9 & 1,6 & 37 & 7,4 & 46 & 4,4 \\
\hline Tentativa de furto & 10 & 1,8 & 45 & 9,0 & 55 & 5,2 \\
\hline Porte ilegal de arma & 20 & 3,6 & 39 & 7,8 & 59 & 5,6 \\
\hline Tráfico de drogas & 56 & 10,1 & 36 & 7,2 & 92 & 8,7 \\
\hline Porte de entorpecente & - & - & 4 & 0,8 & 4 & 0,4 \\
\hline Sequiestro e cárcere privado & 3 & 0,5 & 1 & 0,2 & 4 & 0,4 \\
\hline Estupro & 33 & 6,0 & 13 & 2,7 & 46 & 4,4 \\
\hline Tentativa de estupro & 12 & 2,1 & 4 & 0,8 & 16 & 1,5 \\
\hline Atentado violento ao pudor & 45 & 8,1 & 15 & 3,0 & 60 & 5,7 \\
\hline Lesão corporal dolosa & 1 & 0,2 & 1 & 0,2 & 2 & 0,2 \\
\hline Extorsão & 2 & 0,4 & 2 & 0,4 & 4 & 0,4 \\
\hline Extorsão/seqüestro & 2 & 0,4 & - & - & 2 & 0,2 \\
\hline Estelionato & 5 & 0,9 & 7 & 1,4 & 12 & 1,1 \\
\hline Quadrilha/bando & 1 & 0,2 & 1 & 0,2 & 2 & 0,2 \\
\hline Receptação dolosa & 17 & 3,1 & 23 & 4,6 & 40 & 3,8 \\
\hline Outros & 2 & 0,4 & 9 & 1,8 & 11 & 1,1 \\
\hline Ignorado & 1 & 0,2 & - & - & 1 & 0,1 \\
\hline TOTAL & 553 & 100,0 & 499 & 100,0 & 1.052 & $\overline{100,0}$ \\
\hline
\end{tabular}


O delito atual mais freqüente, entre os detentos, foi o roubo. Do total de 1.052 presos, 421 (40,0\%), haviam praticado este crime. Em seguida, vieram o tráfico de drogas, com $92(8,7 \%)$; a tentativa de roubo, com 88 (8,4\%); o atentado violento ao pudor, com 60 (5,7\%); o porte ilegal de arma, com 59 (5,6\%); a tentativa de furto, com $55(5,2 \%)$ e o homicídio, com $54(5,1 \%)$ detentos.

Entre os 553 detentos primários, os crimes mais comuns foram o roubo, praticado por $235(42,5 \%)$ presos, o tráfico de drogas por $56(10,1 \%)$, a tentativa de roubo por $53(9,6 \%)$, o atentado violento ao pudor por $45(8,1 \%)$ e o homicídio por $25(4,5 \%)$ detentos.

Entre os 499 detentos reincidentes, os delitos mais freqüentes foram o roubo, cometido por $186(37,3 \%)$ presos, a tentativa de furto por $45(9,0 \%)$, o porte ilegal de arma por $39(7,8 \%)$, o furto por $37(7,4 \%)$ e o tráfico de drogas por $36(7,2 \%)$ detentos.

Observou-se que o roubo, foi o principal crime cometido tanto pelos detentos primários como pelos reincidentes. Comparando-se o $2^{\circ}$ delito atual mais freqüente entre estes 2 grupos, constatou-se que, dos 553 detentos primários, $23(4,2 \%)$ haviam praticado a corrupção de menores e $353(63,8 \%)$ não haviam cometido um $2^{\circ}$ delito. Dos 499 detentos reincidentes, 28 (5,6\%) tinham como $2^{\circ}$ delito mais freqüente o porte ilegal de arma e 347 (69,5\%) não haviam cometido um $2^{\circ}$ delito.

Em relação ao $3^{\circ}$ delito atual cometido por estes detentos, o mais freqüente entre os 553 primários foi o uso de documento falso, com $5(0,9 \%)$ detentos, sendo que $495(89,5 \%)$ deles, não haviam cometido um $3^{\circ}$ delito. Dos 499 detentos reincidentes, $7(1,4 \%)$ tinham como $3^{\circ}$ delito mais freqüente a corrupção de menores e $454(91,0 \%)$ não haviam cometido um $3^{\circ}$ delito.

$\mathrm{O} 4^{\circ}$ delito atual mais praticado pelos 553 detentos primários, foi a tentativa de roubo, com $2(0,4 \%)$ detentos cometendo este crime, sendo que $531(96,0 \%)$ deles não haviam cometido um $4^{\circ}$ delito. Dos 499 detentos reincidentes, $3(0,6 \%)$ haviam resistido à prisão e $483(96,8 \%)$ não haviam cometido um $4^{\circ}$ delito.

O $5^{\circ}$ delito atual mais freqüente, foi o desacato, cometido por $1(0,2 \%)$ detento primário, e a receptação dolosa por $1(0,2 \%)$ reincidente. Dos 553 detentos 
primários e dos 499 detentos reincidentes, 545 (98,6\%) e 495 (99,2\%), respectivamente, não haviam cometido um $5^{\circ}$ delito.

Segundo o ILANUD ${ }^{31}$ 1997, desde os anos 50 os "crimes contra o patrimônio" predominam sobre os "crimes contra a pessoa". Esta característica não somente se manteve no tempo, como tendeu a acentuar-se, passando de $44 \%$ do total de crimes nos anos 50, para $61 \%$ em 1997. Fato este, também observado neste trabalho.

No CENSO PENITENCIÁRIO DE $1997^{42}$ 1998, o delito mais freqüente cometido pela população carcerária brasileira, também foi o roubo, com uma taxa $32,8 \%$ dos detentos, sendo que na população carcerária dos Distritos Policiais estudados, este percentual foi de $40 \%$. Em seguida vieram o homicídio, com um percentual de $15,5 \%$ na população carcerária brasileira e de $5,1 \%$ na população dos Distritos Policiais; o tráfico de drogas com $13,7 \%$ e $8,7 \%$, respectivamente; o furto com $12,2 \%$ e $4,4 \%$; e o estupro com $5,2 \%$ na população carcerária brasileira e $4,4 \%$ nos Distritos Policiais da Zona Oeste da Cidade de São Paulo.

O DEPEN ${ }^{44} 2002$, informou que os crimes mais praticados pela população carcerária nacional foram, em primeiro lugar, os "crimes contra o patrimônio" (38\%); em seguida, os "crimes contra a pessoa" (27,2\%), os "crimes hediondos $(19,5 \%)$ e o "crime de tráfico de drogas" $(13,6 \%)$.

Segundo o chefe do Comando do Policiamento da Região Oeste, os “crimes contra o patrimônio" são os mais comuns na Zona Oeste da Cidade de São Paulo. "Esta região é bastante atípica, porque mistura regiões extremamente nobres com áreas extremamente pobres. Nas áreas mais pobres, o crime que mais preocupa é o homicídio e na parte mais nobre, o roubo. Muitos marginais saem das favelas, vão para os semáforos e roubam veículos e pessoas" ${ }^{\text {17 }}$.

A Zona Oeste da Capital Paulista detém um ponto crítico onde o número de assaltos e furtos de veículos é assustador. Trata-se da região de Pinheiros e Vila Madalena, que concentram mais bares por metro quadrado do que qualquer outro local da cidade ${ }^{17}$.

Do total de 1.052 presos, 44 (4,2\%) estavam jurados de morte e encarcerados nos "corrós" ou "seguros" dos Distritos Policiais; ou porque o crime cometido por eles era muito grave, ou porque haviam delatado outros presos. 
A distribuição de detentos por delito cometido, era mais ou menos uniforme em 8 dos 9 Distritos Policiais da Zona Oeste da Cidade de São Paulo. A única exceção foi o $14^{\circ}$ DP em Pinheiros, que abrigava, especialmente, os que haviam cometido crimes sexuais como estupro, tentativa de estupro e atentado violento ao pudor. Esta separação era devida ao grande risco de morte que estes presos sofreriam em outras Delegacias, por haverem praticado crimes inaceitáveis à "ética" carcerária.

Fazendo-se uma análise dos 499 detentos reincidentes, observou-se que, em relação à prisão anterior, $262(52,5 \%)$ já haviam sido presos uma vez e 237 (47,5\%) mais de uma vez.

Dos 237 detentos com mais de uma detenção, 112 (47,2\%) estavam encarcerados pela $2^{\mathrm{a}}$ vez, $50(21,1 \%)$ pela $3^{\mathrm{a}}$ vez, $30(12,7 \%)$ pela $4^{\mathrm{a}}$ vez e 45 $(19,0 \%)$ já haviam sido presos 5 vezes ou mais.

Segundo informações do $\mathrm{DEPEN}^{44}$ 2002, na população carcerária brasileira, $56,4 \%$ dos presos reincidentes haviam sido presos uma vez e 43,6\% mais de uma vez. Observou-se que os dados desta pesquisa foram concordantes com estas informações.

Em relação ao local onde cumpriram penas anteriores, do total de 499 reincidentes, $306(61,4 \%)$ detentos as cumpriram em Distritos Policiais, 85 (17,0\%) em Presídios no Interior do Estado de São Paulo, 50 (10,0\%) na Casa de Detenção, 28 (5,6\%) na FEBEM, 15 (3,0\%) na Penitenciária do Estado, 8 (1,6\%) em Presídios de outros Estados Brasileiros e 7 (1,4\%) em Centros de Detenção Provisória (CDP).

Pelos dados acima, observa-se novamente o grave e crônico problema, de presos cumprindo penas nos Distritos Policiais, pois apenas 3,0\% dos detentos reincidentes haviam sido encaminhados à Penitenciária do Estado.

Quanto ao tempo de prisão anterior, $249(49,9 \%)$ detentos reincidentes permaneceram encarcerados por até 1 ano, $176(35,3 \%)$ por 1 a 5 anos, $47(9,4 \%)$ por até 10 anos e $27(5,4 \%)$ por mais de 10 anos.

Os principais delitos cometidos anteriormente pelos 499 detentos reincidentes encontram-se na Tabela 12: 
Tabela 12 - Distribuição do número e percentagem dos detentos reincidentes, segundo o delito anterior. Distritos Policiais da Zona Oeste da Cidade de São Paulo, 2000-2001.

\begin{tabular}{c|rr}
\hline DELITO ANTERIOR & $\mathbf{N}^{\mathbf{o}}$ & $\mathbf{\%}$ \\
\hline Homicídio & 21 & 4,2 \\
Tentativa de homicídio & 3 & 0,6 \\
Roubo & 105 & 21,0 \\
Tentativa de roubo & 3 & 0,6 \\
Furto & 50 & 10,0 \\
Tentativa de furto & 2 & 0,4 \\
Porte ilegal de arma & 14 & 2,8 \\
Tráfico de drogas & 21 & 4,2 \\
Porte de entorpecente & 1 & 0,2 \\
Estupro & 4 & 0,8 \\
Atentado violento ao pudor & 5 & 1,0 \\
Estelionato & 4 & 0,8 \\
Receptação dolosa & 7 & 1,4 \\
Outros & 2 & 0,4 \\
Ignorado & 257 & 51,5 \\
\hline TOTAL & $\mathbf{4 9 9}$ & $\mathbf{1 0 0 , 0}$ \\
\hline
\end{tabular}

O que chamou a atenção, foi a quantidade de delitos anteriores que não constavam nos prontuários dos detentos, demonstrando o quanto esses prontuários eram falhos. De 499 detentos reincidentes, 257 (51,5\%) não tinham a informação de quais delitos haviam praticado, anotada em seu prontuário, prejudicando a análise da vida pregressa dos mesmos.

Excluindo-se deste estudo os detentos cujos delitos anteriores não foram informados, restaram 242 detentos reincidentes para serem analisados. 
Portanto, os principais delitos cometidos anteriormente pelos 242 reincidentes, foram o roubo, com $105(43,4 \%)$ detentos; em seguida vieram o furto, com 50 (20,7\%) detentos; o homicídio, com 21 (8,7\%); o tráfico de drogas, com 21 $(8,7 \%)$, além de $45(18,5 \%)$ detentos reincidentes que haviam cometido outros delitos.

Comparando-se o delito anterior cometido pelos detentos reincidentes, com o delito atual (motivo pelo qual estavam presos no momento da pesquisa), observou-se que:

- dos 105 reincidentes por roubo, 44 (41,9\%) estavam presos novamente pelo mesmo motivo, $13(12,4 \%)$ por tentativa de roubo, $7(6,7 \%)$ por furto, $5(4,7 \%)$ por tráfico de drogas, 2 (1,9\%) por homicídio, 2 (1,9\%) por tentativa de estupro, $1(1,0 \%)$ por latrocínio (roubo seguido de morte) e $31(29,5 \%)$ por outros motivos.

- dos 50 detentos reincidentes por furto, $15(30,0 \%)$ estavam presos novamente pelo mesmo motivo, $8(16,0 \%)$ por roubo, $3(6,0 \%)$ por tráfico de drogas, $1(2,0 \%)$ por homicídio, $1(2,0 \%)$ por tentativa de homicídio e 22 (44\%) por outros motivos.

- dos 21 detentos reincidentes por homicídio, 7 (33,3\%) haviam cometido o mesmo crime novamente, 2 (9,5\%) estavam presos por furto, 2 $(9,5 \%)$ por tráfico de drogas, $1(4,8 \%)$ por tentativa de homicídio, $1(4,8 \%)$ por estupro, $1(4,8 \%)$ por roubo e $7(33,3 \%)$ por outros crimes.

- dos 21 detentos reincidentes por tráfico de drogas, $8(38,1 \%)$ estavam presos novamente pelo mesmo crime, $4(19,0 \%)$ por roubo, $1(4,8 \%)$ por furto e $8(38,1 \%)$ por outros crimes.

Estes dados mostram que, além de reincidirem no mesmo crime, os detentos passaram a cometer uma diversidade de outros delitos, muitos deles mais graves do que os cometidos anteriormente, demonstrando a falência do sistema carcerário da cidade de São Paulo.

Em relação à situação da tuberculose na população carcerária dos Distritos Policiais da Zona Oeste da Cidade de São Paulo, de acordo com a SECRETARIA DE ESTADO DA SAÚDE ${ }^{70}$ 1999, nas "Recomendações para o controle da tuberculose nas prisões", a maior parte dos detentos em nosso país ingressam nas 
prisões já infectados pelo Mycobacterium tuberculosis e as condições de confinamento favorecem tanto a evolução de infecção para doença, como a sua transmissão. Os profissionais que trabalham no sistema prisional e os visitantes são também submetidos à altos riscos de contrair tuberculose. Além disso, quando os detentos voltam ao convívio social, a transmissão da tuberculose torna-se um problema para a comunidade na qual estes presos serão inseridos novamente.

Entre os 1.052 detentos encarcerados nos Distritos Policiais da Zona Oeste da Cidade de São Paulo, 39 (3,7\%) já haviam tido tuberculose no passado. A distribuição desses casos, segundo a faixa etária, está na Tabela 13.

Tabela 13 - Distribuição do número e percentagem dos detentos que tiveram tuberculose anteriormente, segundo a faixa etária. Distritos Policiais da Zona Oeste da Cidade de São Paulo, 2000-2001.

\begin{tabular}{c|cc}
\hline FAIXA ETÁRIA & $\mathbf{N}^{\mathbf{0}}$ & \% \\
\hline De 18 a 29 anos & 17 & 43,6 \\
De 30 a 39 anos & 14 & 35,9 \\
De 40 a 49 anos & 3 & 7,7 \\
De 50 a 59 anos & 2 & 5,1 \\
60 anos e mais & 3 & 7,7 \\
Ignorada & 0 & 0,0 \\
\hline TOTAL & $\mathbf{3 9}$ & $\mathbf{1 0 0 , 0}$ \\
\hline
\end{tabular}

Observa-se que $17(43,6 \%)$ detentos, que tiveram tuberculose no passado, pertenciam atualmente à faixa etária de 18 a 29 anos e $14(35,9 \%)$ à faixa de 30 a 39 anos de idade, representando 79,5\% dos detentos com tuberculose anterior. Durante o inquérito, estes detentos nos informaram que tiveram algumas recaídas, devido à interrupção do tratamento. 
Destes 39 detentos, $18(46,1 \%)$ haviam sido tratados em Presídios, 11 $(28,2 \%)$ em Centros de Saúde, 8 (20,5\%) em hospitais, 1 (2,6\%) na residência e 1 $(2,6 \%)$ em lugar não especificado.

Apenas 16 detentos $(41,0 \%)$ fizeram o tratamento completo de 6 meses. Dos 23 restantes, $14(35,9 \%)$ trataram menos de 6 meses e $9(23,1 \%)$ mais de 6 meses.

Inquiridos se haviam tido contato anterior com alguma pessoa com tuberculose, do total de 1.052 detentos, apenas 274 (26,0\%) referiram este contato. Destes 274 detentos, 193 (70,4\%) informaram que o contato havia sido no Presídio, com detentos doentes; $70(25,6 \%)$ que havia sido na residência com familiares e vizinhos doentes; 8 (2,9\%) no local de trabalho, com colegas tuberculosos e $3(1,1 \%)$ em outros locais não especificados.

Em relação ao tempo que durou este contato anterior, dos 274 detentos, 15 $(5,5 \%)$ afirmaram que foi menos de 1 mês, $145(52,9 \%)$ de 1 a 6 meses, $44(16,1 \%)$ de mais de 6 meses a 1 ano, $69(25,2 \%)$ de mais de 1 ano e $1(0,4 \%)$ não soube responder.

Durante a aplicação do inquérito individual nos 1.052 detentos encarcerados nos Distritos Policiais da Zona Oeste da Cidade de São Paulo, ao serem inquiridos se, atualmente, apresentavam algum sintoma de tuberculose, 641 (60,9\%)) não referiram sintomas e $411(39,1 \%)$ eram sintomáticos. Os sintomas mais freqüentes referidos pelos 411 detentos sintomáticos estão na Tabela 14: 
Tabela 14 - Distribuição do número e percentagem dos detentos sintomáticos, segundo os sintomas de tuberculose. Distritos Policiais da Zona Oeste da Cidade de São Paulo, 20002001.

\begin{tabular}{c|cc}
\hline SINTOMAS & $\mathbf{N}^{\mathbf{0}}$ & $\mathbf{\%}$ \\
\hline Tosse com expectoração & 345 & 83,9 \\
Febre & 17 & 4,1 \\
Dor torácica & 26 & 6,4 \\
Perda de peso & 17 & 4,1 \\
Perda de apetite & 2 & 0,5 \\
Hemoptise & 4 & 1,0 \\
\hline TOTAL & $\mathbf{4 1 1}$ & $\mathbf{1 0 0 , 0}$ \\
\hline
\end{tabular}

Observa-se, que o sintoma mais freqüente foi tosse com expectoração, referida por $345(83,9 \%)$ detentos.

De acordo com TOMAN ${ }^{77} 1979$, estudos socio-epidemiológicos realizados em uma população rural da Índia, verificaram que 95,0\% dos pacientes com baciloscopia positiva, apresentaram um ou mais sintomas sugestivos de tuberculose. Aproximadamente, $70,0 \%$ referiram a tosse como o principal sintoma. O tempo de duração dos sintomas, para cerca de dois terços dos doentes, foi de 1 a 3 meses.

$\mathrm{O}$ autor relata ainda, que em outro estudo de busca de casos em uma população de, aproximadamente, 6 milhões de pessoas, cerca de 1.600 pacientes com baciloscopia positiva foram inquiridos sobre sintomas de tuberculose e 73,0\% referiram tosse como principal ou segundo sintoma mais importante. Para 62,0\% dos pacientes, o tempo de duração dos sintomas foi inferior a 3 meses.

PICON $^{57}$ e col. 1993, observaram que $98,8 \%$ dos doentes com tuberculose pulmonar apresentavam tosse como principal sintoma da doença. 
Pela sua magnitude, esse sintoma é usado para a estratégia de busca de casos de tuberculose.

Segundo o MINISTÉRIO DA SAÚDE ${ }^{49}$ 2002, a taxa esperada de sintomáticos respiratórios na população geral é de $1 \%$. Neste estudo, para uma população de 1.052 detentos, o número esperado de sintomáticos respiratórios seria de 10 detentos, porém o número encontrado foi de 345, ou seja, 34,5 vezes mais que na população geral.

Do total de 1.052 detentos, $262(24,9 \%)$ referiram ter 2 sintomas de tuberculose, $172(16,3 \%)$ tinham 3 sintomas, $99(9,4 \%) 4$ sintomas e $55(5,2 \%) 5$ sintomas.

A Tabela 15 mostra o tempo de sintomas de tuberculose referidos pelos 411 detentos sintomáticos

Tabela 15 - Distribuição do número e percentagem dos detentos sintomáticos, segundo o tempo de sintomas de tuberculose. Distritos Policiais da Zona Oeste da Cidade de São Paulo, 2000-2001.

\begin{tabular}{c|cc}
\hline TEMPO DE SINTOMAS & $\mathbf{N}^{\mathbf{0}}$ & $\mathbf{\%}$ \\
\hline < que 3 semanas & 216 & 52,6 \\
3 semanas a 2 meses & 122 & 29,7 \\
> que 2 a 6 meses & 45 & 10,9 \\
> que 6 meses a 1 ano & 22 & 5,4 \\
> que 1 ano & 3 & 0,7 \\
Ignorado & 3 & 0,7 \\
\hline TOTAL & $\mathbf{4 1 1}$ & $\mathbf{1 0 0 , 0}$ \\
\hline
\end{tabular}

Nesta tabela, observa-se que, dos 411 detentos com sintomas de tuberculose, $216(52,6 \%)$ os apresentaram em menos de 3 semanas e $122(29,7 \%)$ no período de 3 
semanas a 2 meses, totalizando $338(82,3 \%)$ detentos cujos sintomas se manifestaram em um período de até 2 meses.

Dos 1.052 presos, $932(88,6 \%)$ concordaram em fazer a prova tuberculínica (PPD) e estavam presentes no momento da leitura da mesma.

Devido à constante mobilidade da população carcerária dos Distritos Policiais, $13(1,2 \%)$ dos 1.052 detentos não realizaram a leitura, ou porque estavam no Fórum, ou porque haviam sido transferidos para outros Presídios, ou porque haviam obtido alvará de soltura. Outros 107 (10,2\%) detentos não realizaram a prova; alguns pelos motivos citados acima, mas o motivo principal foi a recusa.

Portanto, para uma melhor análise dos dados, foram considerados apenas os resultados obtidos nos detentos que fizeram e leram a prova tuberculínica, sendo ainda separados em primários e reincidentes, de acordo com a sua situação carcerária.

Como citado anteriormente, dos 1.052 detentos encarcerados nos Distritos Policiais, 553 (52,6\%) eram primários e 499 (47,4\%) eram reincidentes.

Dos 553 detentos primários, 47 (8,5\%) foram excluídos, porque 5 não fizeram a leitura e 42 não realizaram o teste, restando 506 (91,5\%) detentos primários para serem analisados. Dos 499 detentos reincidentes, foram excluídos 73 (14,6\%), dos quais 8 não estavam presentes no momento da leitura e 65 não haviam feito o teste, restando $426(85,4 \%)$ detentos reincidentes. Portanto, um total de 932 detentos, que fizeram a prova tuberculínica completa, foram analisados.

O resultado da prova tuberculínica (PPD) aplicada em 932 detentos primários e reincidentes dos Distritos Policiais, e classificados como reatores e não reatores à prova encontra-se na Tabela 16: 
Tabela 16 - Distribuição do número e percentagem dos detentos primários e reincidentes, segundo o resultado da prova tuberculínica. Distritos Policiais da Zona Oeste da Cidade de São Paulo, 20002001 .

\begin{tabular}{c|cccc|cc}
\hline \multirow{2}{*}{$\begin{array}{c}\text { PROVA } \\
\text { TUBERCULÍNICA }\end{array}$} & \multicolumn{2}{|c|}{ PRIMÁRIOS } & \multicolumn{2}{c}{ REINCIDENTES } & \multicolumn{2}{c}{ TOTAL } \\
(PPD) & $\mathbf{N}^{\mathbf{0}}$ & $\%$ & $\mathbf{N}^{\mathbf{0}}$ & $\boldsymbol{\%}$ & $\mathbf{N}^{\mathbf{0}}$ & $\boldsymbol{\%}$ \\
\hline Não reator & 227 & 44,9 & 104 & 24,4 & $\mathbf{3 3 1}$ & $\mathbf{3 5 , 5}$ \\
Reator & 279 & 55,1 & 322 & 75,6 & $\mathbf{6 0 1}$ & $\mathbf{6 4 , 5}$ \\
\hline TOTAL & $\mathbf{5 0 6}$ & $\mathbf{1 0 0 , 0}$ & $\mathbf{4 2 6}$ & $\mathbf{1 0 0 , 0}$ & $\mathbf{9 3 2}$ & $\mathbf{1 0 0 , 0}$ \\
\hline
\end{tabular}

Esta tabela mostra que, dos 932 detentos analisados, $601(64,5 \%)$ foram reatores ao PPD, ou seja, estavam infectados.

Entre os 506 detentos primários, $279(55,1 \%)$ ingressaram nos Distritos Policiais já infectados e dos 426 detentos reincidentes, 322 (75,6\%) reingressaram no sistema prisional infectados, revelando uma taxa de infecção bem maior nos presos reincidentes, do que nos primários.

Estes resultados são concordantes com os encontrados por NIERO ${ }^{52} 1981$, nos detentos da Casa de Detenção de São Paulo. A prova tuberculínica foi realizada em 9.532 presos, sendo que a taxa média de infecção tuberculosa foi de 54,1\% nos detentos primários e, de $81,5 \%$ nos reincidentes.

SÁNCHEZ e col. ${ }^{69} 1995$ realizaram a prova tuberculínica em 1.084 detentos de uma prisão na Espanha, dos quais 602 (55,5\%) estavam infectados pelo $M$. tuberculosis, ou seja, foram reatores fortes ao PPD. Esta percentagem encontrada foi comparável à população penitenciária da Catalonia, estudada por MARTíN e col. ${ }^{40}$ 1994, que havia sido de 56,2\%.

MARTÍN e col. ${ }^{41}$ 2000, realizaram outro estudo em 1999, na população encarcerada em um Centro Penitenciário na Espanha e encontraram um percentual de 
58,0\% de detentos infectados pelo M. tuberculosis; e citam que, em 1998, havia sido observada uma prevalência de infecção tuberculosa de 50,6\%, em detentos encarcerados nos Centros Penitenciários da Espanha.

ADIB e col. ${ }^{1} 1999$ fizeram um levantamento em 1995, visando conhecer a prevalência de infecção pelo M. tuberculosis em 3.931 detentos das 21 prisões do Líbano. A positividade ao PPD foi de 45,0\%.

$\mathrm{Na}$ população prisional da América do Norte, a prevalência de infecção tuberculosa variou de $12,8 \%$ a $24,0 \%{ }^{69}$, porém, em dois estudos realizados na Califórnia, esta percentagem foi um pouco maior. TULSKY e col. ${ }^{78} 1998$, encontraram a prevalência de $26,9 \%$ em detentos da cidade de São Francisco e o CDC $^{11}$ 1993, relatou uma percentagem de infecção de 30,0\%, nos detentos de uma Prisão Estadual, no período de 1990-1991.

Em termos mundiais, a maior prevalência de infecção pelo $M$. tuberculosis na população geral, encontra-se na região oeste do Pacífico, com 44,0\%, e a mais baixa, no leste do Mediterrâneo, com 19,0\%. As demais regiões têm percentuais intermediários entre esses dois extremos. As Américas, excluindo-se os Estados Unidos e Canadá, têm o percentual de $25,9 \%$ de infectados ${ }^{63}$.

Dos 601 detentos reatores à prova tuberculínica, 36 (6,0\%) apresentaram flictena ou necrose no local da aplicação.

As principais características dos 601 detentos reatores ao PPD eram as seguintes: $410(68,2 \%)$ pertenciam à faixa etária de 18 a 29 anos; 321 (53,4\%) eram pretos ou pardos; $396(65,9 \%)$ não haviam completado o $1^{\circ}$ grau escolar; 269 $(44,8 \%)$ eram ajudantes gerais ou não tinham profissão. Portanto, os presos reatores eram na maioria jovens, com pouca escolaridade e baixo nível sócio-econômico.

Comparando-se a leitura da prova tuberculínica com os principais sintomas referidos pelos detentos, observa-se na Tabela 17, que dos 932 detentos testados com PPD, 557 (59,8\%) não tinham sintomas de tuberculose, 314 (33,7\%) referiram como principal sintoma a tosse com expectoração, ou seja, eram sintomáticos respiratórios, e $61(6,5 \%)$ apresentaram outros sintomas. 
Tabela 17 - Distribuição do número e percentagem dos detentos que fizeram a prova tuberculínica, segundo sintomas de tuberculose. Distritos Policiais da Zona Oeste da Cidade de São Paulo, 20002001.

\begin{tabular}{|c|c|c|c|c|c|c|}
\hline \multirow[t]{3}{*}{ SINTOMAS } & \multicolumn{4}{|c|}{ PROVA TUBERCULÍNICA (PPD) } & \multicolumn{2}{|c|}{ TOTAL } \\
\hline & \multicolumn{2}{|c|}{ Não reator } & \multicolumn{2}{|c|}{ Reator } & $\mathbf{N}^{\mathbf{0}}$ & $\%$ \\
\hline & & $\%$ & $\mathrm{n}^{\mathrm{o}}$ & $\%$ & $\mathbf{N}$ & $\%$ \\
\hline Sem sintomas & 202 & 36,3 & 355 & 63,7 & 557 & 100,0 \\
\hline Tosse & 107 & 34,1 & 207 & 65,9 & 314 & 100,0 \\
\hline Febre & 4 & 26,7 & 11 & 73,3 & 15 & 100,0 \\
\hline Dor torácica & 10 & 38,5 & 16 & 61,5 & 26 & 100,0 \\
\hline Perda de peso & 8 & 53,3 & 7 & 46,7 & 15 & 100,0 \\
\hline Perda de apetite & - & - & 2 & 100,0 & 2 & 100,0 \\
\hline Hemoptise & - & - & 2 & 100,0 & 2 & 100,0 \\
\hline Ignorado & - & - & 1 & 100,0 & 1 & 100,0 \\
\hline TOTAL & 331 & 35,5 & 601 & 64,5 & 932 & 100,0 \\
\hline
\end{tabular}

Observa-se que, do total de 557 detentos que se declararam "sem sintomas", $355(63,7 \%)$ foram reatores ao PPD e dos 314 sintomáticos respiratórios, 207 $(65,9 \%)$ também foram reatores, demonstrando o alto grau de infecção tuberculosa nos detentos.

A Tabela 18 compara o resultado da prova tuberculínica com o tempo de permanência dos detentos nos Distritos Policiais da Zona Oeste da Cidade de São Paulo. 
Tabela 18 - Distribuição do número e percentagem dos detentos que fizeram a prova tuberculínica, segundo o tempo de permanência nos Distritos Policiais da Zona Oeste da Cidade de São Paulo, 20002001.

\begin{tabular}{|c|c|c|c|c|c|c|}
\hline \multirow{3}{*}{$\begin{array}{c}\text { TEMPO DE } \\
\text { PERMANENCIA } \\
\text { (EM DIAS) } \\
\end{array}$} & \multicolumn{4}{|c|}{ PROVA TUBERCULÍNICA (PPD) } & \multicolumn{2}{|c|}{ TOTAL } \\
\hline & \multicolumn{2}{|c|}{ Não reator } & \multicolumn{2}{|c|}{ Reator } & \multirow{2}{*}{$\mathbf{N}^{\mathbf{o}}$} & \multirow[t]{2}{*}{$\%$} \\
\hline & $\mathrm{n}^{\mathrm{o}}$ & $\%$ & $n^{o}$ & $\%$ & & \\
\hline$<60$ & 120 & 42,9 & 160 & 57,1 & 280 & $\overline{100,0}$ \\
\hline 60 a 180 & 122 & 35,6 & 221 & 64,4 & 343 & 100,0 \\
\hline 181 a 365 & 69 & 29,9 & 162 & 70,1 & 231 & 100,0 \\
\hline$>366$ & 20 & 25,6 & 58 & 74,4 & 78 & 100,0 \\
\hline TOTAL & 331 & 35,5 & 601 & 64,5 & 932 & $\overline{100,0}$ \\
\hline
\end{tabular}

O que se destaca nesta tabela, é que à medida que o tempo de prisão aumenta maior a percentagem de detentos reatores ao PPD e menor a de não reatores.

Para verificar-se a associação entre tempo de prisão e reatividade ao PPD, utilizou-se o teste de tendência, separando os detentos em primários e reincidentes, e em não reatores e reatores.

O Gráfico 1 compara o resultado da prova tuberculínica com o tempo de permanência dos detentos primários nos Distritos Policiais da Zona Oeste da Cidade de São Paulo e o Gráfico 2 faz a mesma comparação para os detentos reincidentes. 
Gráfico 1 - Percentagem de detentos primários, não reatores e reatores à prova tuberculínica, segundo o tempo de permanência nos Distritos Policiais da Zona Oeste da Cidade de São Paulo, 2000-2001.

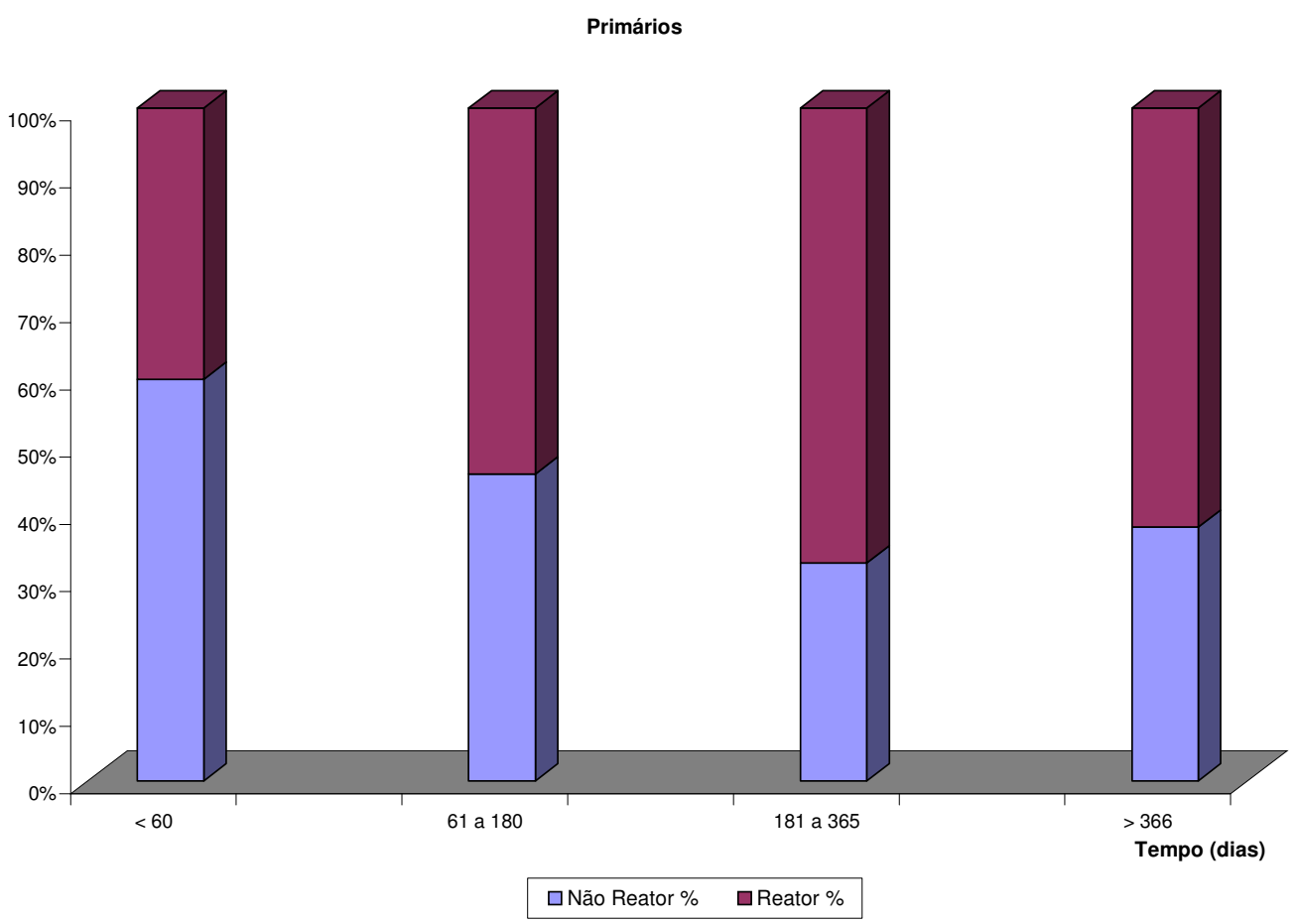

No gráfico apresentado, verifica-se a existência de associação entre o tempo de permanência dos detentos primários nos Distritos Policiais da Zona Oeste da Cidade de São Paulo e a reatividade ao teste tuberculínico, utilizando-se o teste de tendência $(\mathrm{p}<0,001)$.

Dos 506 detentos primários analisados, 134 estavam presos há menos de 60 dias, e destes, 40,3\% foram reatores ao PPD e 59,7\% não reatores. Dos 180 detentos primários com 60 a 180 dias de prisão, a percentagem de reatores aumentou para 64,4\% e a dos não reatores diminuiu para 45,6\%. Dos 139 detentos com 181 a 365 dias de prisão, a percentagem de reatores aumentou para 67,6\% e a dos não reatores diminuiu para 32,4\%. Dos 53 detentos primários com mais de 366 dias de prisão, a percentagem de infectados foi de $62,3 \%$ e a de não infectados de $37,7 \%$, havendo 
uma ligeira queda na percentagem dos infectados. Mesmo assim, o gráfico mostra que, quanto maior o tempo de prisão, maior o número de detentos reatores ao PPD.

Segundo SÁNCHES e col. ${ }^{69} 1995$, esta relação entre infecção e tempo de prisão, tem sido demonstrada em outros estudos, nos quais se observou que, quanto maior a permanência do detento em uma prisão, maior é sua exposição à doença e maior o risco de infecção.

Gráfico 2 - Percentagem de detentos reincidentes, não reatores e reatores à prova tuberculínica, segundo o tempo de permanência nos Distritos Policiais da Zona Oeste da Cidade de São Paulo, 20002001.

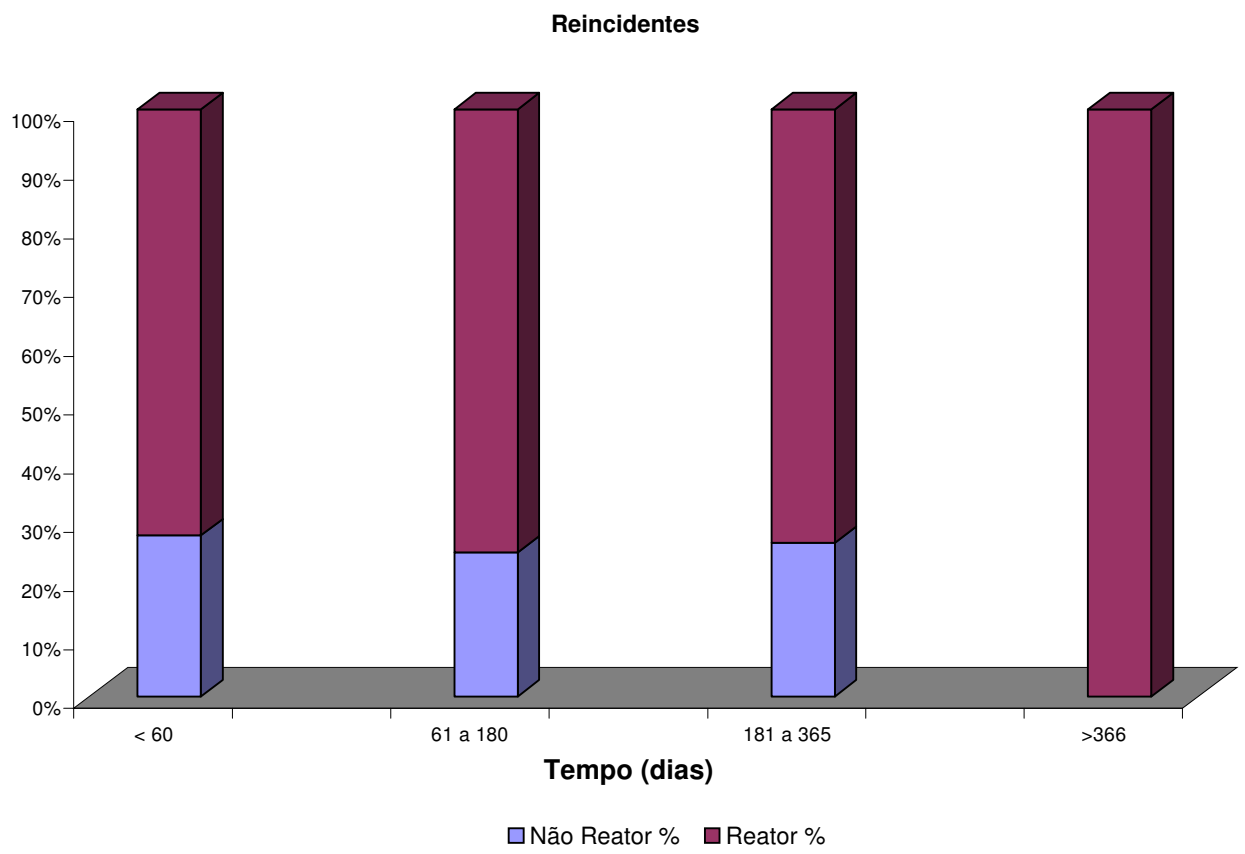

No gráfico dos detentos reincidentes, também se verificou a existência de associação entre o tempo de permanência destes detentos nos Distritos Policiais da Zona Oeste da Cidade de São Paulo e a reatividade ao teste tuberculínico, utilizandose o teste de tendência $(\mathrm{p}<0,001)$.

Dos 426 detentos reincidentes analisados, 146 estavam presos há menos de 60 dias, e destes, 72,6\% foram reatores ao PPD e 27,4\% não reatores. Dos 163 detentos 
reincidentes com 60 a 180 dias de prisão, a percentagem de reatores aumentou para 75,5\% e a dos não reatores diminuiu para 24,5\%. Dos 92 detentos com 181 a 365 dias de prisão, a percentagem de reatores foi de $73,9 \%$ e a dos não reatores de $26,1 \%$. O que se destaca neste gráfico, é que dos 25 detentos reincidentes com mais de 366 dias de prisão, 100,0\% estava infectado, mostrando que os detentos reincidentes apresentaram maiores percentagens de infecção tuberculosa desde que reingressaram na prisão, e que estas, foram aumentando na medida em que aumentava o tempo de prisão destes detentos.

Portanto, comparando-se os 2 gráficos apresentados, observa-se que, em todos os períodos de permanência na prisão, os detentos reincidentes tiveram maior percentagem de infecção tuberculosa do que os detentos primários; sendo que, no período superior à 366 dias de prisão, 100,0\% dos detentos reincidentes estavam infectados.

Em concordância com a SECRETARIA DE ESTADO DA SAÚDE ${ }^{70} 1999$, que afirma, nas "Recomendações para o controle da tuberculose nas prisões", que a maior parte dos detentos em nosso país ingressa nas prisões já infectados, constatouse neste estudo, que realmente a maior parte dos detentos dos Distritos Policiais da Zona Oeste da Cidade de São Paulo ingressaram nas carceragens já infectados, pois dos 932 detentos que fizeram e leram a prova tuberculínica, 57,1\% daqueles que estavam presos há menos de 60 dias, foram reatores ao PPD.

Entretanto, quando foram analisados os detentos primários e reincidentes segundo o tempo de prisão, observou-se que entre aqueles que estavam encarcerados há menos de 60 dias (não havendo, portanto, tempo hábil para se tornarem infectados na prisão), 59,7\% dos primários, ingressaram nos Distritos Policiais não infectados, ou seja, não haviam sido reatores ao PPD, e 27,4\% dos reincidentes, reingressaram no sistema prisional não infectados, demonstrando a necessidade de se fazer essa análise, de acordo com a situação carcerária dos detentos e com o tempo de prisão dos mesmos, para se avaliar a real percentagem de infectados na população carcerária, no momento da prisão.

Uma informação praticamente impossível de ser obtida, por meio de um questionário ou consulta aos prontuários dos detentos, foi a soropositividade ao HIV, pois apenas $11(1,0 \%)$ dos 1.052 detentos analisados nesta pesquisa admitiram ser 
portadores do vírus. Para a obtenção deste dado, haveria a necessidade de se fazer um teste sangüíneo em cada preso, cuja realização não seria possível no Laboratório de Micobactérias da Faculdade de Saúde Pública.

Quanto à realização dos exames laboratoriais para o diagnóstico da tuberculose, que foram a baciloscopia e a cultura de escarro, para posterior identificação das cepas isoladas e teste de sensibilidade às drogas antituberculose, do total de 1.052 detentos encarcerados nos Distritos Policiais da Zona Oeste da Cidade de São Paulo, 35 (3,3\%) não realizaram os exames, totalizando 1.017 (96,7\%) presos que aceitaram colher o material biológico para a realização desta pesquisa.

Os motivos para a não realização de 35 exames de baciloscopia e cultura de escarro foram os seguintes: 17 detentos $(48,6 \%)$ se recusaram a colher o escarro; 7 $(20,0 \%)$ não conseguiram colher o material biológico; 5 (14,3\%) foram libertados com alvará de soltura; 4 (11,4\%) foram transferidos para outros Presídios, e 2 (5,7\%) estavam no Fórum.

COELHO e col. ${ }^{13} 1999$ salientaram que apesar da baciloscopia representar o principal recurso diagnóstico da tuberculose, por demonstrar a presença do agente etiológico da doença e identificar os casos bacilíferos para serem tratados, acrescido de seu baixo custo e simplicidade, suas limitações demandam a realização da cultura.

A baciloscopia apresenta uma sensibilidade 22 a $49 \%$ menor do que a cultura e impossibilita o isolamento da micobactéria, o que inviabiliza a identificação e o estudo da resistência frente aos atuais quimioterápicos ${ }^{13}$.

O método de cultura recomendado pelo MINISTÉRIO DA SAÚDE ${ }^{45} 1994$, é o da técnica de Petroff com semeadura em meio de Lowenstein-Jensen, que possui uma certa complexidade técnica e um custo razoável para a aquisição de equipamentos, como centrífugas e agitadores de tubos.

Preocupados com a escassez de recursos materiais e humanos existentes nos laboratórios brasileiros, Coelho e colaboradores, avaliaram a técnica simplificada de Ogawa-Kudoh para o isolamento de micobactérias. Observaram um índice de crescimento micobacteriano maior e mais rápido, talvez devido a uma melhor distribuição bacilar na superfície do meio, por causa do processo de semeadura com "swabs" (zaragatoas), além de uma menor contaminação e satisfatórias taxas de sensibilidade $(79 \%)$ e especificidade $(94 \%)^{13}$. 
Destacaram algumas vantagens oferecidas pelo método:

- O processo de descontaminação é simples e rápido, não necessitando de equipamentos e pessoal técnico especializado;

- A manipulação reduzida da amostra e a não utilização de mecanismos de agitação/centrifugação, favorece a execução da técnica em laboratórios de menor complexidade, reduzindo a produção de aerossóis e, consequentemente, a contaminação ambiental e do pessoal de laboratório;

Depois de semeado, o meio pode ser mantido à temperatura ambiente por até 20 dias, caso seja necessário ser enviado a um Laboratório Regional para ser incubado $^{13}$.

Por estes motivos, neste estudo, a cultura foi realizada pelos métodos de descontaminação de Petroff e Ogawa-Kudoh (segundo técnica padronizada pelo Instituto Adolfo Lutz de São Paulo ${ }^{10}$ ), com posterior semeadura nos meios de Lowenstein-Jensen e Ogawa-Kudoh.

Para uma melhor análise dos dados, os cálculos para se avaliar a positividade dos exames laboratoriais foram baseados nos 1.017 detentos que realizaram os exames.

Os resultados dos exames de baciloscopia de escarro destes detentos, estão apresentados na Tabela 19:

Tabela 19 - Distribuição do número e percentagem dos detentos, segundo o resultado da baciloscopia de escarro. Distritos Policiais da Zona Oeste da Cidade de São Paulo, 2000-2001.

\begin{tabular}{c|rr}
\hline BACILOSCOPIA DE ESCARRO & $\mathbf{N}^{\mathbf{0}}$ & $\boldsymbol{\%}$ \\
\hline Negativa & 1009 & 99,2 \\
Positiva & 8 & 0,8 \\
\hline TOTAL & $\mathbf{1 . 0 1 7}$ & $\mathbf{1 0 0 , 0}$ \\
\hline
\end{tabular}


A positividade da baciloscopia, do total de escarros examinados nos detentos dos Distritos Policiais, foi de $8(0,8 \%)$.

No Brasil, em 2000, o número de casos de tuberculose com forma pulmonar bacilífera foi de 49.925 casos para uma população de 169.872 .856 habitantes, com uma taxa de $29,4 / 100.000^{26,30}$. Na população da cidade de São Paulo, segundo dados do $\mathrm{CVE}^{72}$, a taxa foi de 26,1/100.000 habitantes.

Pelo resultado da baciloscopia, o coeficiente de prevalência de tuberculose com forma pulmonar bacilífera, entre os detentos dos Distritos Policiais da Zona Oeste da Cidade de São Paulo, foi de 787/100.000 detentos, ou seja, aproximadamente 26 vezes mais que o da população do Brasil e 30 vezes mais que o da cidade de São Paulo. Estes dados confirmaram que a prevalência da tuberculose na população prisional é muito maior do que na população geral.

Comparando-se a leitura da prova tuberculínica com a baciloscopia, observou-se que do total de 8 baciloscopias positivas, $5(62,5 \%)$ detentos foram reatores fortes ao PPD e $3(37,5 \%)$ não realizaram o teste.

Os 8 detentos diagnosticados com tuberculose, pela baciloscopia de escarro, encontravam-se nos seguintes Distritos Policiais: 2 estavam no $7^{\circ}$ DP na Lapa, 2 no $46^{\circ}$ DP em Perus, 2 no $87^{\circ}$ DP em Pereira Barreto, 1 no $33^{\circ}$ DP em Pirituba e 1 no $37^{\circ}$ DP em Campo Limpo.

Os resultados da cultura de escarro dos detentos encontram-se na Tabela 20:

Tabela 20 - Distribuição do número e percentagem dos detentos, segundo o resultado da cultura de escarro. Distritos Policiais da Zona Oeste da Cidade de São Paulo, 2000-2001.

\begin{tabular}{c|rr}
\hline CULTURA DE ESCARRO & $\mathbf{N}^{\mathbf{0}}$ & $\boldsymbol{\%}$ \\
\hline Negativa & 963 & 94,7 \\
Positiva & 54 & 5,3 \\
\hline TOTAL & $\mathbf{1 . 0 1 7}$ & $\mathbf{1 0 0 , 0}$ \\
\hline
\end{tabular}


A positividade da cultura dos escarros dos detentos foi de 54 (5,3\%). Nestas 54 culturas positivas, estão incluídas as 8 baciloscopias positivas. Portanto, a realização da cultura aumentou em 6,8 vezes a positividade do diagnóstico da tuberculose nos detentos.

Pelo resultado da cultura, o coeficiente de prevalência de tuberculose, com forma pulmonar bacilífera, entre os detentos dos Distritos Policiais da Zona Oeste da Cidade de São Paulo foi de 5.310/100.000 detentos, ou seja, aproximadamente 180 vezes mais que o da população do Brasil e 203 vezes mais que o da cidade de São Paulo, reforçando a importância da busca de casos neste segmento populacional, devido à grande prevalência da doença nestas comunidades.

Comparando-se o resultado da cultura com a leitura da prova tuberculínica, observou-se que do total de 54 detentos com cultura positiva, $34(63,0 \%)$ foram reatores ao PPD, $13(24,1 \%)$ foram não reatores, 2 (3,7\%) não fizeram a leitura do PPD e $5(9,2 \%)$ não realizaram a prova.

Chamou a atenção o número de detentos com cultura positiva e que não foram reatores à prova tuberculínica. As causas prováveis para essa ocorrência, talvez tenham sido a falta de informação a respeito da soropositividade dos detentos ao HIV, a possibilidade destes detentos serem portadores de cepas de micobactérias não tuberculosas (MNT), ou outros fatores que mereceriam estudos mais aprofundados.

A distribuição dos 54 detentos encarcerados nos Distritos Policiais da Zona Oeste da Cidade de São Paulo, que tiveram cepas de micobactérias isoladas na cultura de escarro, está apresentada na Tabela 21: 
Tabela 21 - Distribuição do número e percentagem dos detentos com cultura positiva, nos Distritos Policiais da Zona Oeste da Cidade de São Paulo, 2000-2001.

\begin{tabular}{c|rr}
\hline DISTRITOS POLICIAIS & $\mathbf{N}^{\mathbf{o}}$ & $\mathbf{\%}$ \\
\hline Lapa $-7^{\circ} \mathrm{DP}$ & 14 & 25,9 \\
Pinheiros $-14^{\circ} \mathrm{DP}$ & 1 & 1,8 \\
Pirituba $-33^{\circ} \mathrm{DP}$ & 17 & 31,5 \\
Morumbi $-34^{\circ} \mathrm{DP}$ & 5 & 9,3 \\
Campo Limpo $-37^{\circ} \mathrm{DP}$ & 8 & 14,8 \\
Perus $-46^{\circ} \mathrm{DP}$ & 4 & 7,4 \\
Pereira Barreto $-87^{\circ} \mathrm{DP}$ & 3 & 5,6 \\
Ceasa $-91^{\circ} \mathrm{DP}$ & 2 & 3,7 \\
\hline TOTAL & $\mathbf{5 4}$ & $\mathbf{1 0 0 , 0}$ \\
\hline
\end{tabular}

Como mostra a tabela, os Distritos Policiais que abrigavam mais presos cultura-positivos foram o $33^{\circ} \mathrm{DP}$ em Pirituba, com 17 (31,5\%) detentos, o $7^{\circ} \mathrm{DP}$ na Lapa, com $14(25,9 \%)$ e o $37^{\circ}$ DP em Campo Limpo, com 8 (14,8\%) detentos com cultura positiva.

A comparação dos sintomas de tuberculose referidos pelos detentos, com os resultados da baciloscopia e cultura, está na Tabela 22: 
Tabela 22 - Distribuição do número e percentagem dos detentos, segundo os resultados da baciloscopia e cultura e sintomas de tuberculose. Distritos Policiais da Zona Oeste da Cidade de São Paulo, 20002001.

\begin{tabular}{c|cccccccc}
\hline \multirow{2}{*}{ SINTOMAS } & \multicolumn{3}{|c}{ BACILOSCOPIA } & \multicolumn{3}{c}{ CULTURA } \\
& \multicolumn{2}{|c}{ Positiva } & \multicolumn{2}{c}{ Negativa } & \multicolumn{2}{c}{ Positiva } & \multicolumn{2}{c}{ Negativa } \\
& $\mathrm{n}^{\mathbf{0}}$ & $\%$ & \multicolumn{1}{c}{$\mathrm{n}^{\mathbf{0}}$} & $\%$ & $\mathrm{n}^{\mathbf{0}}$ & $\%$ & $\mathrm{n}^{\mathbf{0}}$ & $\%$ \\
\hline Sem sintomas & 2 & 25,0 & 610 & 60,4 & 28 & 51,8 & 584 & 60,6 \\
Tosse & 5 & 62,5 & 335 & 33,2 & 21 & 38,9 & 319 & 33,1 \\
Febre & 1 & 12,5 & 15 & 1,5 & 2 & 3,7 & 14 & 1,5 \\
Dor torácica & - & - & 25 & 2,5 & 3 & 5,6 & 22 & 2,3 \\
Perda de peso & - & - & 17 & 1,7 & - & - & 17 & 1,8 \\
Perda de apetite & - & - & 2 & 0,2 & - & - & 2 & 0,2 \\
Hemoptise & - & - & 4 & 0,4 & - & - & 4 & 0,4 \\
Ignorado & - & - & 1 & 0,1 & - & - & 1 & 0,1 \\
\hline TOTAL & $\mathbf{8}$ & $\mathbf{1 0 0 , 0}$ & $\mathbf{1 0 0 9}$ & $\mathbf{1 0 0 , 0}$ & $\mathbf{5 4}$ & $\mathbf{1 0 0 , 0}$ & $\mathbf{9 6 3}$ & $\mathbf{1 0 0 , 0}$ \\
\hline
\end{tabular}

Quanto aos sintomas referidos pelos detentos, dos 8 que tiveram a baciloscopia positiva, $5(62,5 \%)$ eram sintomáticos respiratórios, $1(12,5 \%)$ referiu febre como principal sintoma, e $2(25,0 \%)$ não referiram sintomas. Dos 54 que tiveram a cultura positiva, $21(38,9 \%)$ também apresentavam tosse com expectoração como principal sintoma, $2(3,7 \%)$ referiram febre, $3(5,6 \%)$ dor torácica, e 28 $(51,8 \%)$ não apresentavam sintomas de tuberculose.

Chamou a atenção, o fato de que 51,8\% dos detentos com cultura positiva não relataram sintomas.

As 54 cepas de micobactérias isoladas na cultura de escarro dos detentos, foram enviadas para o Laboratório de Micobactérias do Instituto Adolfo Lutz da cidade de São Paulo, onde realizou-se a identificação das mesmas. Os resultados estão mostrados na Tabela 23: 
Tabela 23 - Distribuição do número e percentagem dos detentos, segundo a identificação das cepas de micobactérias isoladas na cultura de escarro. Distritos Policiais da Zona Oeste da Cidade de São Paulo, 2000-2001.

\begin{tabular}{c|cc}
\hline $\begin{array}{c}\text { IDENTIFICAÇÃO DAS CEPAS } \\
\text { ISOLADAS }\end{array}$ & $\mathbf{N}^{\mathbf{0}}$ & \% \\
\hline M. tuberculosis & 21 & 38,9 \\
M. fortuitum & 21 & 38,9 \\
M. chelonae & 1 & 1,8 \\
Complexo M. fortuitum/M. chelonae & 7 & 13,0 \\
M. nonchromogenicum & 1 & 1,8 \\
Micobactéria de crescimento rápido & & 5,6 \\
acromógena & 3 & - \\
Outras & - & $\mathbf{1 0 0 , 0}$ \\
\hline TOTAL & $\mathbf{5 4}$ &
\end{tabular}

Estes dados mostram que, das 54 cepas de micobactérias isoladas na cultura de escarro dos detentos dos Distritos Policiais da Zona Oeste da Cidade de São Paulo, 21 (38,9\%) foram identificadas como M. tuberculosis e $33(61,1 \%)$ como micobactérias não tuberculosas (MNT).

Comparando-se o resultado da baciloscopia com o teste de identificação das cepas de micobactérias isoladas nos escarros dos detentos, observou-se que os 8 detentos com baciloscopia positiva, tiveram suas cepas identificadas como Mycobacterium tuberculosis.

Dos 54 detentos que tiveram as cepas de micobactérias isoladas na cultura de escarro e identificadas, $6(11,1 \%)$ já haviam tido tuberculose no passado, sendo que 3 $(5,6 \%)$ estavam novamente com a doença, uma vez que suas cepas foram identificadas como $M$. tuberculosis e $3(5,6 \%)$ detentos tiveram suas cepas identificadas como M. fortuitum. 
Pelos resultados do teste de identificação, considerando-se apenas os 21 casos cujas cepas foram identificadas como M. tuberculosis, o coeficiente de prevalência de tuberculose com forma pulmonar bacilífera, entre os detentos dos Distritos Policiais da Zona Oeste da Cidade de São Paulo, foi de 2.065/100.000 detentos, ou seja, aproximadamente, 70 vezes maior que o da população do Brasil e 79 vezes mais que o da cidade de São Paulo.

Estes 21 detentos portadores de cepas identificadas como M. tuberculosis, estavam encarcerados nos seguintes Distritos Policiais (Tabela 24):

Tabela 24 - Distribuição do número e percentagem dos detentos portadores de cepas identificadas como M. tuberculosis. Distritos Policiais da Zona Oeste da Cidade de São Paulo, 2000-2001.

\begin{tabular}{c|cc}
\hline $\begin{array}{c}\text { DISTRITOS POLICIAIS } \\
\text { (DP) }\end{array}$ & $\mathbf{N}^{\mathbf{0}}$ & $\boldsymbol{\%}$ \\
\hline Lapa $-7^{\circ} \mathrm{DP}$ & 6 & 28,6 \\
Pirituba $-33^{\circ} \mathrm{DP}$ & 2 & 9,5 \\
Morumbi $-34^{\circ} \mathrm{DP}$ & 2 & 9,5 \\
Campo Limpo $-37^{\circ}$ DP & 2 & 9,5 \\
Perus $-46^{\circ}$ DP & 4 & 19,1 \\
Pereira Barreto $-87^{\circ}$ DP & 3 & 14,3 \\
Ceasa $-91^{\circ}$ DP & 2 & 9,5 \\
\hline TOTAL & $\mathbf{2 1}$ & $\mathbf{1 0 0 , 0}$ \\
\hline
\end{tabular}

Observou-se que dos 21 detentos que tiveram suas cepas identificadas como M. tuberculosis, $6(28,6 \%)$ estavam encarcerados no $7^{\circ}$ Distrito Policial, na Lapa, que na época da pesquisa, abrigava 149 detentos em 5 celas.

Em relação aos sintomas referidos pelos 21 detentos doentes, $11(52,4 \%)$ referiram tosse com expectoração como principal sintoma, ou seja, eram 
sintomáticos respiratórios, $1(4,8 \%)$ referiu febre, $1(4,8 \%)$ apresentou dor torácica e $8(38,0 \%)$ não tinham sintomas.

Dos 33 detentos portadores de cepas de MNT, 10 (30,3\%) eram sintomáticos respiratórios, $1(3,0 \%)$ relatou febre como principal sintoma, $2(6,1 \%)$ apresentaram dor torácica e 20 (60,6\%) não tinham sintomas de tuberculose.

Observou-se uma menor quantidade de detentos sintomáticos respiratórios, naqueles que tiveram suas cepas identificadas como MNT.

A distribuição dos 33 detentos portadores de cepas identificadas como micobactérias não tuberculosas (MNT), nos Distritos Policiais da Zona Oeste da Cidade de São Paulo, encontra-se na Tabela 25:

Tabela 25 - Distribuição do número e percentagem dos detentos portadores de cepas identificadas como micobactérias não tuberculosas (MNT). Distritos Policiais da Zona Oeste da Cidade de São Paulo, 2000-2001.

\begin{tabular}{c|cc}
\hline $\begin{array}{c}\text { DISTRITOS POLICIAIS } \\
\text { (DP) }\end{array}$ & $\mathbf{N}^{\mathbf{o}}$ & $\boldsymbol{\%}$ \\
\hline Lapa $-7^{\circ} \mathrm{DP}$ & 8 & 24,2 \\
Pinheiros $-14^{\circ} \mathrm{DP}$ & 1 & 3,0 \\
Pirituba $-33^{\circ} \mathrm{DP}$ & 15 & 45,5 \\
Morumbi $-34^{\circ} \mathrm{DP}$ & 3 & 9,1 \\
Campo Limpo $-37^{\circ} \mathrm{DP}$ & 6 & 18,2 \\
\hline TOTAL & $\mathbf{3 3}$ & $\mathbf{1 0 0 , 0}$ \\
\hline
\end{tabular}

Observou-se que dos 33 detentos, cujas cepas foram identificadas como MNT, 15 (45,5\%) estavam encarcerados no $33^{\circ} \mathrm{DP}$, em Pirituba e $8(24,2 \%)$ no $7^{\circ}$ DP, na Lapa. 
As "micobactérias não tuberculosas" (MNT), ou "atípicas", são espécies de micobactérias não pertencentes ao complexo Mycobacterium tuberculosis e não Mycobacterium leprae $e^{3,28,34,54,79}$.

São encontradas naturalmente no meio ambiente, no solo, poeira, água, leite, plantas e excretas de aves e animais domésticos, no mundo todo, e inclui mais de 65 espécies diferentes. Geralmente são saprófitas, mas, aproximadamente, um terço das espécies identificadas são patógenos oportunistas em humanos e animais, causando infecções cutâneas, teciduais, ósseas, pulmonares e doenças disseminadas (principalmente em pacientes imunocomprometidos) ) $^{3,5,28,34,54,56,67,79}$.

Estas infecções são denominadas micobacterioses, e resultam das seguintes localizações do bacilo: pulmão, brônquios, pleura, gânglios linfáticos, ossos, articulações, pele, peritônio e outras ${ }^{3,34}$.

Consequentemente, as "micobactérias não tuberculosas" podem ser encontradas na saliva, escarro, urina e lavado gástrico, sem causar doenças. Principalmente nos isolamentos respiratórios, micobactérias ambientais podem colonizar as vias aéreas, sem significado clínico ${ }^{28,56,79}$.

Entretanto, quando ocorre, a doença pulmonar por MNT é mais comum em homens na faixa etária de 30 a 50 anos, particularmente na presença de fatores predisponentes, tais como: tuberculose residual, bronquiectasia, doença pulmonar obstrutiva crônica, fibrose cística, silicose, deficiência imunológica e outras 3,28,34,56,67. Neste trabalho, os 3 detentos que haviam tido tuberculose no passado e agora tiveram suas cepas identificadas como $M$. fortuitum, tinham 18, 42 e 43 anos de idade, respectivamente.

A baixa virulência da MNT condiciona a sua patogenicidade à diminuição da resistência do hospedeiro. Entretanto, ocasionalmente, elas podem ser responsáveis por iniciar ou perpetuar doença pulmonar em adultos, invadindo lesões preexistentes. Determinam quadros clínicos passíveis de confusão com a tuberculose pulmonar ou extrapulmonar, além de não responderem ao tratamento quimioterápico ${ }^{3,28}$.

Afetam, sobretudo, pacientes imunodeprimidos devido a transplante de órgãos, deficiência renal crônica, corticosteróide terapia e portadores de HIV, em regiões onde a prevalência da tuberculose é baixa ${ }^{3,28}$. 
No Brasil, na década 1989-99, observou-se uma taxa de 2,5\% de isolamentos de MNT, no momento da notificação dos casos de AIDS. Nos países industrializados, os percentuais de isolamento variam de 25 a $50 \%{ }^{5,28}$.

BARRETO e CAMPOS $^{5} 2000$ relataram que, no período de 1994-99 foram identificadas 590 culturas de MNT no Laboratório de Tuberculose do Centro de Referência Prof. Hélio Fraga, Rio de Janeiro, das quais 433 (73,4\%) foram isoladas do pulmão dos pacientes. Do total de espécies identificadas, $262(44,4 \%)$ eram $M$. avium-intracellulare, 81 (13,7\%) M. kansasii, 64 (10,8\%) M. fortuitum, 9 (1,5\%) M. chelonae e $174(29,5 \%)$ outras espécies ${ }^{5}$.

Os autores citaram também que, em uma pesquisa anterior, Campos e colaboradores estudaram a prevalência de MNT no Brasil, em 5.488 pacientes ambulatoriais bacilíferos de 13 capitais brasileiras, no período de 1995-96, e encontraram a taxa de 5,83 por mil pacientes. Os isolamentos de M. aviumintracellulare, $M$. kansasii e $M$. fortuitum não apresentaram diferença estatística entre eles 5 .

No presente estudo, das 54 cepas de micobactérias isoladas na cultura de escarro dos 1.017 detentos analisados nos Distritos Policiais da Zona Oeste da Cidade de São Paulo, 33 (61,1\%) foram identificadas como micobactérias não tuberculosas (MNT).

O isolamento das MNT é importante porque se confundem com o bacilo da tuberculose no diagnóstico, podendo substituí-lo patologicamente nas lesões, e epidemiologicamente na coletividade; provocam doença semelhante à tuberculose, com as mais diversas localizações; estão largamente difundidas na natureza e nos animais, mesmo sem produzir doença; sensibilizam o organismo humano, dando reações cruzadas com a tuberculina PPD-RT23 e específicas com sensitinas homólogas (tuberculina preparada com MNT) ${ }^{3,28}$.

A sintomatologia é idêntica à da tuberculose: tosse persistente, febre baixa, perda de peso e fadiga. A hemoptise tem sido relatada em $30,5 \%$ dos casos, sendo duas vezes mais freqüente do que na tuberculose clássica ${ }^{3,28}$.

Nesta pesquisa, dos 33 detentos que tiveram suas cepas identificadas como micobactérias não tuberculosas (MNT), 10 (30,3\%) eram sintomáticos respiratórios, ou seja, apresentavam tosse com expectoração como principal sintoma, $1(3,0 \%)$ 
apresentou febre, $2(6,1 \%)$ dor torácica e $20(60,6 \%)$ não apresentaram sintomas de tuberculose.

A transmissão direta humano-para-humano dessas micobactérias, é considerada rara $^{3,5,28,54,67,79}$.

As MNT têm causado muitos surtos em hospitais, contaminando estações de tratamento de água e sistemas de abastecimento, equipamentos e instrumentos cirúrgicos, sendo isoladas de água de torneira, chuveiros, piscinas de hidroterapia, máquinas de hemodiálise, broncoscópios, reagentes, desinfetantes, agulhas e seringas, etc. ${ }^{28,53,55,62}$ Esta contaminação resulta em terapia desnecessária contra $M$. tuberculosis nos pacientes afetados, uma vez que as MNT são resistentes à maioria das drogas antituberculose de primeira linha ${ }^{28,54}$.

Entre as MNT, as pertencentes ao grupo IV de Runyon são de crescimento rápido. Nos meios de cultura utilizados na rotina bacteriológica crescem em 3 a 7 dias a $25-40^{\circ} \mathrm{C}$. Neste grupo encontra-se o complexo M. fortuitum/M. chelonae, que abrange as espécies $M$. fortuitum, $M$. peregrinum, $M$. chelonae, M. abscessus (anteriormente classificado como uma subespécie do $M$. chelonae) e $M$. mucogenicum, sendo que apenas o M. fortuitum, M. chelonae e M. abscessus são patogênicos para o homem ${ }^{28,38,54,67}$.

As experiências com sensitinas (antígenos preparados com MNT, por técnica semelhante à da tuberculina) mostram alta reatividade cruzada e baixa especificidade. Assim, o teste cutâneo pode ser útil, mas não para a confirmação diagnóstica $^{3,54}$.

Na prova tuberculínica com PPD-RT23 2UT, ou maiores concentrações de tuberculina, as reações são pouco intensas, geralmente menores de $10 \mathrm{~mm}$. Portanto, quando indivíduos sintomáticos respiratórios forem fraco-reatores à tuberculina, deve-se suspeitar que estejam infectados com outras micobactérias (MNT) e não com o bacilo da tuberculose $e^{3,38}$. Entretanto, neste estudo, dos 31 detentos portadores de cepas de MNT que fizeram a prova tuberculínica, 19 (61,3\%) foram reatores fortes ao PPD-RT23.

As técnicas laboratoriais utilizadas para as MNT são basicamente as mesmas da tuberculose por M. tuberculosis: baciloscopia, cultura, identificação da espécie e teste de sensibilidade às drogas antituberculose $e^{3,28,54,67}$. 
Geralmente a baciloscopia é negativa, porque o material biológico é paucibacilar. Na cultura, diferenciam-se do $M$. tuberculosis devido aos seus caracteres culturais, pigmentação e velocidade de crescimento. A determinação da espécie deve ser feita por métodos bioquímicos. Quanto ao teste de sensibilidade, deve-se ampliar o número de drogas a serem testadas (tetraciclina, amicacina, sulfas, eritromicina e outras), uma vez que as MNT apresentam percentuais elevados de resistência ${ }^{3,28,34,54,67}$.

O tratamento das micobacterioses pode ser quimioterápico ou cirúrgico, dependendo da forma clínica e sensibilidade da micobactéria aos antibióticos recomendados $3,54,67$.

Como o número de isolamentos de MNT, em material patológico excede muito o número de pessoas doentes, foram estabelecidos alguns critérios para o diagnóstico das micobacterioses:

1- presença abundante de colônias nas culturas;

2- isolamento exclusivo e repetido da mesma micobactéria por mais de 3 vezes, da mesma origem, num período de poucos dias, para excluir a existência de saprófitas ocasionais do material patológico ou de contaminantes. A presença em lesão fechada (abscesso ou biópsia) é sinal de patogenicidade;

3- processo compatível com a doença, determinado por imagens radiológicas e sintomas clínicos evidentes. Estes sinais não têm especificidade e não permitem suspeitar do caráter atípico do agente causal;

4- modificações histopatológicas quando é possível a biópsia e, eventualmente, o isolamento do bacilo da lesão;

5- exclusão de outros germes patogênicos, especialmente do bacilo da tuberculose ou de outras espécies colonizadoras. O isolamento junto com o bacilo da tuberculose, antes da terapêutica específica, só passa a ter significado quando a MNT persistir na lesão;

6- intradermorreação positiva com sensitina homóloga. A falta de sensibilidade deste antígeno, limita o seu uso ${ }^{3,28}$.

Seguindo estes critérios, a orientação contida nos laudos de resultados dos exames de identificação das cepas isoladas nos detentos dos Distritos Policiais da 
Zona Oeste da Cidade de São Paulo, fornecidos pelo Laboratório de Micobactérias do Instituto Adolfo Lutz da cidade de São Paulo, foi a seguinte: "as outras micobactérias identificadas, que não a $M$. tuberculosis, são classificadas como potencialmente patogênicas, mas só poderiam estar relacionadas com doença, se isoladas repetidamente do mesmo sítio e em cultivos puros e abundantes, para excluir o seu caráter colonizador transitório ou contaminante".

Coincidência ou não, todos os 33 detentos que tiveram suas cepas identificadas como não tuberculosas, estavam envolvidos em escavação de túneis para fuga, em contato direto com terra e água do solo, durante o período desta pesquisa.

O encontro de cepas de MNT na população carcerária deveria alertar os epidemiologistas sobre a importância da realização da identificação e teste de sensibilidade das micobactérias isoladas de escarros de detentos, pois a hipótese de uma infecção pulmonar por "micobactéria não tuberculosa" (micobacteriose) deve ser sempre formulada, especialmente quando um indivíduo diagnosticado e tratado como tuberculoso, não apresenta resposta satisfatória à quimioterapia convencional, principalmente, se apresentar algum fator predisponente.

Para a comparação da prova tuberculínica com a identificação das cepas de micobactérias isoladas dos escarros de 54 detentos positivos na cultura, foram excluídos da análise $2(3,7 \%)$ detentos que não fizeram a leitura e $5(9,3 \%)$ que não realizaram a prova, totalizando, portanto, $47(87,0 \%)$ detentos analisados. Pela influência que as MNT exercem na reatividade tuberculínica, para esta análise, os detentos cultura-positivos foram classificados em não reator, reator fraco e reator forte ao PPD. Estes dados estão na Tabela 26: 
Tabela 26 - Distribuição do número e percentagem dos detentos culturapositivos e que fizeram a prova tuberculínica, segundo a identificação das cepas de micobactérias isoladas. Distritos Policiais da Zona Oeste da Cidade de São Paulo, 2000-2001.

\begin{tabular}{|c|c|c|c|c|c|c|c|c|}
\hline \multirow{3}{*}{$\begin{array}{l}\text { IDENTIFICAÇÃO DAS } \\
\text { CEPAS ISOLADAS }\end{array}$} & \multicolumn{6}{|c|}{ PROVA TUBERCULÍNICA (PPD) } & \multirow{2}{*}{\multicolumn{2}{|c|}{ TOTAL }} \\
\hline & \multicolumn{2}{|c|}{ Não reator } & \multicolumn{2}{|c|}{ Reator fraco } & \multicolumn{2}{|c|}{ Reator forte } & & \\
\hline & $\mathrm{n}^{\mathrm{o}}$ & $\%$ & $\mathrm{n}^{\mathrm{o}}$ & $\%$ & $\mathrm{n}^{\mathrm{o}}$ & $\%$ & $\mathbf{N}^{\mathbf{o}}$ & $\%$ \\
\hline M. tuberculosis & 2 & 12,5 & 1 & 6,2 & 13 & 81,3 & 16 & 100,0 \\
\hline M. fortuitum & 7 & 35,0 & - & - & 13 & 65,0 & 20 & 100,0 \\
\hline M. chelonae & - & - & - & - & 1 & 100,0 & 1 & 100,0 \\
\hline C. M. fortuitum/M. chelonae & 2 & 28,6 & 1 & 14,3 & 4 & 57,1 & 7 & 100,0 \\
\hline M. nonchromogenicum & 1 & 100,0 & - & - & - & - & 1 & 100,0 \\
\hline $\begin{array}{l}\text { Micobactéria crescimento } \\
\text { rápido acromógena }\end{array}$ & 1 & 50,0 & - & - & 1 & 50,0 & 2 & 100,0 \\
\hline TOTAL & 13 & 27,7 & 2 & 4,2 & 32 & 68,1 & 47 & 100,0 \\
\hline
\end{tabular}

Observa-se nesta análise que, de 47 detentos com cepas de micobactérias identificadas, $32(68,1 \%)$ foram reatores fortes ao PPD.

Entre os 16 detentos portadores de cepas de M. tuberculosis, que fizeram a prova tuberculínica, $13(81,3 \%)$ foram reatores fortes ao PPD, e entre os 31 portadores de cepas de MNT, 19 (61,3\%) foram reatores fortes ao PPD.

Após a realização do teste de identificação das cepas isoladas na cultura de escarro dos detentos dos Distritos Policiais, as 21 cepas identificadas como $M$. tuberculosis foram submetidas ao teste de sensibilidade às drogas antituberculose, para se averiguar resistência bacteriana; exame este, também realizado no Laboratório de Micobactérias do Instituto Adolfo Lutz da cidade de São Paulo. Os resultados do teste de sensibilidade encontram-se na Tabela 27: 
Tabela 27 - Distribuição do número e percentagem dos detentos, segundo o resultado do teste de sensibilidade às drogas antituberculose nas cepas identificadas como M. tuberculosis, isoladas na cultura de escarro. Distritos Policiais da Zona Oeste da Cidade de São Paulo, 2000-2001.

\begin{tabular}{c|cc}
\hline & & \\
TESTE DE SENSIBILIDADE ÀS & $\mathbf{N}^{\mathbf{0}}$ & $\mathbf{\%}$ \\
DROGAS ANTITUBERCULOSE & & 85,7 \\
Sensível & 18 & 9,5 \\
Resistente a isoniazida e rifampicina & 2 & 4,8 \\
Resistente a isoniazida, rifampicina e & & $\mathbf{1 0 0 , 0}$ \\
\hline pirazinamida & 1 & $\mathbf{2 1}$ \\
\hline TOTAL & & $\mathbf{1 0 0}$
\end{tabular}

Em relação ao resultado da prova tuberculínica, dos 18 detentos portadores de cepas de M. tuberculosis sensíveis às drogas antituberculose, $12(66,7 \%)$ foram reatores ao PPD, 2 (11,1\%) foram não reatores, 1 (5,6\%) não fez a leitura e 3 $(16,6 \%)$ não realizaram a prova.

Comparando-se o resultado da baciloscopia com o teste de sensibilidade às drogas antituberculose, observou-se que, dos 8 detentos com baciloscopia positiva, 7 (87,5\%) eram portadores de cepas de $M$. tuberculosis sensíveis, e 1 (12,5\%) era portador de cepa de $M$. tuberculosis resistente à INH e RMP.

Chamou a atenção, o fato de que os outros 2 detentos que portavam cepas de M. tuberculosis resistentes às drogas antituberculose (inclusive o detento resistente às 3 drogas), eram baciloscopia-negativos e, portanto, só foram identificados pela cultura, ressaltando a importância da realização da cultura para o diagnóstico da tuberculose. 
Dos 21 detentos com tuberculose, 2 (9,5\%) cujas cepas de M. tuberculosis eram sensíveis às drogas antituberculose, e $1(4,8 \%)$ que portava cepa resistente à INH e RMP, haviam tido tuberculose no passado e recebido tratamento por 6 meses.

O detento resistente à INH e RMP, desenvolveu a doença em 1995, tratou, e teve uma recidiva em 1997, recebendo tratamento por mais 8 meses. Em 1999 sofreu nova recidiva e recebeu 5 meses de tratamento com estreptomicina injetável. $\mathrm{Na}$ época da pesquisa, este detento estava na terceira recidiva.

Segundo ele, estes tratamentos foram falhos, pois as drogas antituberculose não eram administradas diariamente, havendo ainda inúmeras interrupções no tratamento, na medida em que ele era transferido para outros Presídios. Como consequiência, este detento desenvolveu uma tuberculose multirresistente. Sabendose doente, ele se recusou a fazer a prova tuberculínica.

Este preso tinha 31 anos de idade, era amasiado (recebia visita íntima) e tinha um filho de 6 anos de idade. Era natural da cidade de São Paulo, de cor parda e analfabeto. Apresentava tosse com expectoração há 30 dias e hemoptise há 20 dias. Estava no Distrito Policial havia 3 semanas, por roubo, e era fugitivo de um presídio do interior do Estado. Sua pena era de 11 anos de reclusão, em regime fechado, e o mais grave foi que, sempre doente, havia passado por vários Distritos Policiais na cidade de São Paulo e por vários Presídios do interior, além de um período na Casa de Detenção e outro na Penitenciária do Estado.

O outro detento resistente à INH e RMP, não referiu tuberculose no passado, não apresentava sintomas da doença, mas foi reator forte ao PPD. Tinha 24 anos de idade, era solteiro, de cor parda e analfabeto. Nascido na cidade de São Paulo, estava no Distrito Policial havia 5 meses, por tráfico de drogas.

O detento portador da cepa resistente às 3 drogas antituberculose, também não referiu tuberculose no passado, mas apresentava todos os sintomas da doença, sendo reator forte ao PPD. Tinha 28 anos de idade, era amasiado e tinha 1 filha de 6 anos de idade. Era de cor branca e havia completado o $1^{\circ}$ grau escolar. Nascido em uma pequena cidade do Paraná, era reincidente e estava no Distrito Policial havia 1 mês, por roubo.

Os 3 detentos com tuberculose resistente às drogas antituberculose, encontravam-se no $7^{\circ} \mathrm{DP}$, na Lapa. 
Destacou-se o fato de que, dos 21 detentos que tiveram suas cepas identificadas como M. tuberculosis, $6(28,6 \%)$ estavam encarcerados no $7^{\circ}$ Distrito Policial, na Lapa, incluindo os 3 presos com tuberculose multirresistente, além de 8 $(24,2 \%)$ dos 33 detentos com cepas de MNT. Assim, os 149 detentos que estavam neste Distrito, na época da pesquisa, sofreram um grande risco de contrair tuberculose ou infecção tuberculosa, inclusive por cepas multirresistentes às drogas antituberculose.

Sabe-se que a quimioterapia deve impedir o desenvolvimento da resistência bacteriana, obter o mais rapidamente possível a negativação bacteriológica, conseguir a cura e evitar recaídas ${ }^{71,75}$. A interrupção precoce do tratamento possibilita a multiplicação das micobactérias que se encontravam em estado de semilatência, causando a recidiva da tuberculose $e^{46,62,71}$.

Segundo o MINISTÉRIO DA SAÚDE ${ }^{49}, 2002$, os resultados de um inquérito nacional de resistência no Brasil, realizado em 1998, demonstraram uma taxa de multidroga-resistência adquirida à isoniazida e rifampicina de 5,7\% e às 3 drogas antituberculose (isoniazida, rifampicina e pirazinamida) de 1,4\%. Nesta pesquisa obtivemos taxas de multidroga-resistência adquirida de $9,5 \%$ e $4,8 \%$, respectivamente.

Outro fator importante a ser destacado é a extrema mobilidade desta população, circulando de uma prisão a outra e retornando ao convívio social, dificultando o diagnóstico de casos bacilíferos; e quando diagnosticados, a falta de controle ou a interrupção do tratamento perpetuam a fonte de infecção e aumentam o risco de casos resistentes às drogas ${ }^{39,70}$.

Portanto, quando um doente é descoberto nestas Instituições, o exame para a identificação da micobactéria e o teste de sensibilidade às drogas antituberculose, tornam-se fundamentais na tentativa de se isolar os casos multirresistentes.

Foi observado neste trabalho que os 9 Distritos Policiais analisados não tinham sistema de saúde próprio e não contavam com a mínima estrutura física para o atendimento aos detentos doentes. Segundo informações dos policiais e da Vigilância Epidemiológica Distrital, quando doentes, os detentos eram atendidos, de maneira precária, pela Unidade de Saúde mais próxima, sendo que este deslocamento dos presos ao local de atendimento envolvia graves problemas de segurança. 
Esta dificuldade de diagnóstico e tratamento da tuberculose nos Distritos Policiais tem ocasionado um número cada vez maior de casos graves e óbitos nos últimos tempos. 


\section{5- CONCLUSÕES}

- Foram estudados 1.052 detentos, e destes:

- 99,7\% eram do sexo masculino,

- 71,3\% pertenciam à faixa etária de 18 a 29 anos de idade,

- 82,4\% eram solteiros ou "amasiados",

- 51,4\% eram pretos ou pardos,

- 64,5\% não haviam completado o $1^{\circ}$ grau escolar,

- 46,2\% estavam desempregados no momento da prisão,

- 81,9\% tinham profissão sendo que a mais citada foi a de "ajudante, auxiliar geral",

- 70,0\% eram provenientes da Região Sudeste do Brasil, e destes, 92,9\% haviam nascido no Estado de São Paulo.

- 52,6\% eram primários e 47,4\% eram reincidentes,

- o delito mais freqüente foi o roubo, cometido por $40,0 \%$ dos detentos,

- 30,9\% já haviam sido julgados e condenados, e cumpriam pena no Distrito Policial,

- 3,7\% já haviam tido tuberculose no passado,

- 39,1\% eram sintomáticos e o sintoma mais frequiente foi a tosse com expectoração e

- 52,6\% dos detentos sintomáticos, apresentaram os sintomas em menos de 3 semanas.

- O número de sintomáticos respiratórios foi 34,5 vezes mais que na população geral.

- A prevalência de infecção tuberculosa nos 932 detentos que realizaram a prova tuberculínica foi de $64,5 \%$.

Entre os que estavam presos há menos de 60 dias, 59,7\% dos primários e $27,4 \%$ dos reincidentes, ingressaram no sistema prisional não infectados.

Entre os reincidentes com mais de 366 dias de prisão, 100,0\% estavam infectados. 
- $1.017(96,7 \%)$ detentos colheram escarro para a realização dos exames laboratoriais.

- A positividade da baciloscopia foi de $8(0,8 \%)$ e o coeficiente de prevalência de tuberculose dos bacilíferos, foi de 787/100.000 detentos, ou seja, aproximadamente 26 vezes mais que o da população do Brasil e 30 vezes mais que o da cidade de São Paulo.

- A positividade da cultura foi de $54(5,3 \%)$ e o coeficiente de prevalência de tuberculose, foi de 5.310/100.000 detentos, ou seja, aproximadamente 180 vezes mais que o da população do Brasil e 203 vezes mais que o da cidade de São Paulo.

- Das 54 cepas de micobactérias isoladas na cultura, 21 (38,9\%) foram identificadas como $M$. tuberculosis e 33 (61,1\%) como micobactérias não tuberculosas (MNT).

- Entre os 21 detentos com cepas de M. tuberculosis, o coeficiente de prevalência de tuberculose, foi de 2.065/100.000 detentos, ou seja, aproximadamente, 70 vezes maior que o da população do Brasil e 79 vezes mais que o da cidade de São Paulo.

- O teste de sensibilidade às drogas antituberculose, das 21 cepas de $M$. tuberculosis, revelou que $18(85,7 \%)$ eram sensíveis às drogas, $2(9,5 \%)$ eram resistentes à isoniazida e rifampicina e 1 (4,8\%) era resistente às 3 drogas antituberculose (isoniazida, rifampicina e pirazinamida).

- 6 detentos com cepas de M. tuberculosis, incluindo os 3 presos com tuberculose multirresistente, e 8 com cepas de MNT, estavam encarcerados no $7^{\circ}$ Distrito Policial, na Lapa. 
- Alguns fatores não mensuráveis, provavelmente, contribuíram para a alta prevalência de tuberculose entre os detentos dos Distritos Policiais da Zona Oeste da Cidade de São Paulo, tais como:

- o confinamento e a superlotação dos Distritos Policiais, que aliados às precárias condições de higiene, à baixa qualidade da alimentação e ao stress causado por esta situação, favorecem tanto a transmissão da tuberculose, como a evolução da infecção para doença,

- as dificuldades operacionais para o diagnóstico dos casos bacilíferos,

- a falta de continuidade no tratamento dos casos diagnosticados, devido à grande mobilidade da população carcerária dos Distritos Policiais, perpetuando a fonte de infecção e aumentando o risco de casos resistentes às drogas antituberculose,

- a falta de um sistema de saúde próprio, para atendimento e isolamento dos doentes,

- a falta de recursos financeiros e vontade política para resolver o problema,

- e a falta de integração e de um fluxo de informação entre as instituições envolvidas, como as Secretarias Estadual e Municipal de Saúde, Secretarias de Segurança Pública e Administração Penitenciária e outras ligadas ao Sistema Penitenciário. 


\section{6- RECOMENDAÇÕES}

Após a análise da grave situação da tuberculose nos detentos encarcerados nos Distritos Policiais da Zona Oeste da Cidade de São Paulo, apresentam-se sugestões gerais e específicas.

\section{1- Gerais}

- Diminuição da superlotação dos Distritos Policiais, que deveriam ser utilizados apenas para detenções de curto prazo.

- Melhoria nas condições gerais da carceragem, como higiene, ventilação e nutrição.

- Separação de presos primários e reincidentes, evitando assim, que as Delegacias continuem sendo escolas do crime.

- Aplicação de mais penas alternativas, como fianças e serviços comunitários; além de benefícios, como o livramento condicional, para os presos de menor periculosidade.

- Encorajamento à reabilitação e oferecimento de atividades produtivas aos detentos, para um retorno bem-sucedido à sociedade.

- Os carcereiros deveriam receber treinamento para lidar com os detentos e, periodicamente, fazer cursos de reciclagem.

- Os Distritos Policiais deveriam ter um médico e/ou um enfermeiro, além de um estoque básico de medicamentos, para evitar o deslocamento dos presos.

\section{2- Específicas}

- Ao ingressarem no sistema prisional, os detentos deveriam realizar a prova tuberculínica, para se conhecer a proporção de infectados pelo Mycobacterium tuberculosis, e um teste para se detectar a infecção pelo HIV.

- Os infectados, especialmente aqueles com maior risco de adoecimento, que são os HIV-positivos, deveriam ser submetidos à quimioprofilaxia com isoniazida, de forma supervisionada por 6 meses.

- Os profissionais dos Distritos Policiais, quando admitidos, também deveriam ser submetidos à prova tuberculínica. 
- O acesso de profissionais da área de saúde às carceragens, deveria ser facilitado.

- É de extrema importância, a realização periódica de uma busca ativa de sintomáticos respiratórios nos detentos dos Distritos Policiais e de outras unidades do sistema prisional, para a detecção precoce dos casos de tuberculose.

- Durante esta busca, após a identificação dos suspeitos, deveria ser colhido o escarro dos detentos sintomáticos respiratórios, para a realização dos exames laboratoriais, visando o diagnóstico da doença, por meio da baciloscopia e cultura, e quando necessário através dos testes de identificação e sensibilidade às drogas antituberculose.

- Aqueles com resultado de baciloscopia e/ou cultura positiva, deveriam ser isolados e tratados, com a finalidade de interromper a transmissão da doença.

- Aqueles com resultado de baciloscopia e cultura negativas, deveriam fazer o Raio $\mathrm{X}$ de tórax e se a radiografia apresentasse imagens sugestivas de tuberculose pulmonar, deveriam iniciar a quimioterapia.

- As dificuldades operacionais para diagnóstico e tratamento dos casos, mesmo os mais simples, deveriam ser objeto de diálogo entre as instituições envolvidas, como as Secretarias Estadual e Municipal de Saúde, Secretarias de Segurança Pública e Administração Penitenciária e outras ligadas ao Sistema Penitenciário.

- O tratamento dos casos de tuberculose, mediante a estratégia da OMS de tratamento supervisionado ou diretamente observado (DOTS), considerada a medida de maior impacto para o controle da doença, deveria ser oferecido à todos os detentos diagnosticados com tuberculose. Neste tratamento, o detento doente deveria ingerir os medicamentos sob a supervisão direta de um profissional devidamente treinado.

- Todos os contatos do detento com tuberculose, como os outros presos que dormem na mesma cela, os familiares e companheiras que o visitam, o carcereiro, e outros que tiverem maior convivência com o doente, deveriam ser investigados.

- É necessário o registro de cada caso de tuberculose, e de outras doenças infecciosas, nos prontuários individuais dos detentos, além da notificação dos casos à Vigilância Sanitária local. 
- Implantação de um sistema de informação eficiente entre os diversos Distritos Policiais e outras instituições envolvidas, já que os detentos são transferidos constantemente.

- É necessário existir um local próprio, para que cada Distrito Policial possa encaminhar seus detentos com tuberculose; pois a oferta de um tratamento adequado para estes pacientes, erradicaria um importante reservatório da doença para a sociedade como um todo. 


\section{7- COMENTÁRIOS FINAIS}

Consideramos que alguns fatos curiosos e observações pessoais deveriam ser registrados neste trabalho, apesar de terem sido poucas as dificuldades encontradas por nossa equipe para a realização do mesmo.

- Nos 2 primeiros Distritos Policiais visitados, ficamos um pouco intimidadas pelas condições precárias das instalações, pela quantidade de detentos encarcerados em um espaço físico tão reduzido, e pela necessidade que os policiais demonstravam em ter os reclusos sob a mira de armas, tamanha era a preocupação dos Investigadores da Polícia Civil com nossa segurança.

- A partir do $3^{\circ}$ Distrito Policial visitado, percebemos que não haveria problemas de segurança se ficássemos sozinhas com os presos na "viúva", sob a vigilância dos policiais, mas sem as armas, pois notamos que os detentos respeitavam os profissionais da saúde.

- Conversamos com os Investigadores da Polícia Civil que nos acompanhavam e com os que trabalhavam no Distrito Policial, e chegamos à um acordo extremamente amigável, que beneficiou a todos. Passamos a trabalhar de forma mais tranqüila e essa atitude contribuiu para uma maior cooperação e adesão à pesquisa, por parte dos detentos.

- Constatamos que os Distritos Policiais não ofereciam infra-estrutura para o trabalho, lazer, educação, visitas e outras atividades para os detentos. Eram prédios com pouco espaço físico para manter presos por um longo período de tempo. A maioria dos prédios possuía 2 pavimentos. No $1^{\circ}$ andar, geralmente, localizavam-se as salas do Delegado Titular do Distrito Policial, do Delegado Assistente, dos Investigadores da Polícia Civil, dos escrivães e respectivos chefes, e a cantina. No térreo, localizavam-se a recepção, a sala do Delegado de plantão, a sala do carcereiro e, no fundo, a carceragem.

- Observamos que os pátios da carceragem eram cobertos com telas de proteção e quando perguntamos o motivo para os policiais, eles nos explicaram que nos casos de fuga, cordas e armas eram arremessadas da rua, por amigos dos presos. Após a colocação das telas, restaram apenas 2 alternativas de fuga: ou escavando 
túneis, ou pela porta da frente, após dominarem o carcereiro (tática denominada "cavalo doido").

- A rotina dos presos era de ociosidade total. Alguns nos disseram que, como não tinham nada para fazer, só pensavam em fugir. Quando estavam no pátio, alguns presos aproveitavam para fazer barba, cortar o cabelo, lavar roupas, escrever cartas, ouvir rádio de pilha, jogar baralho, rezar, conversar, ou andar sem parar para se exercitar.

Para ilustração da infra-estrutura dos prédios, achamos interessante apresentar fotos dos 9 Distritos Policiais estudados.

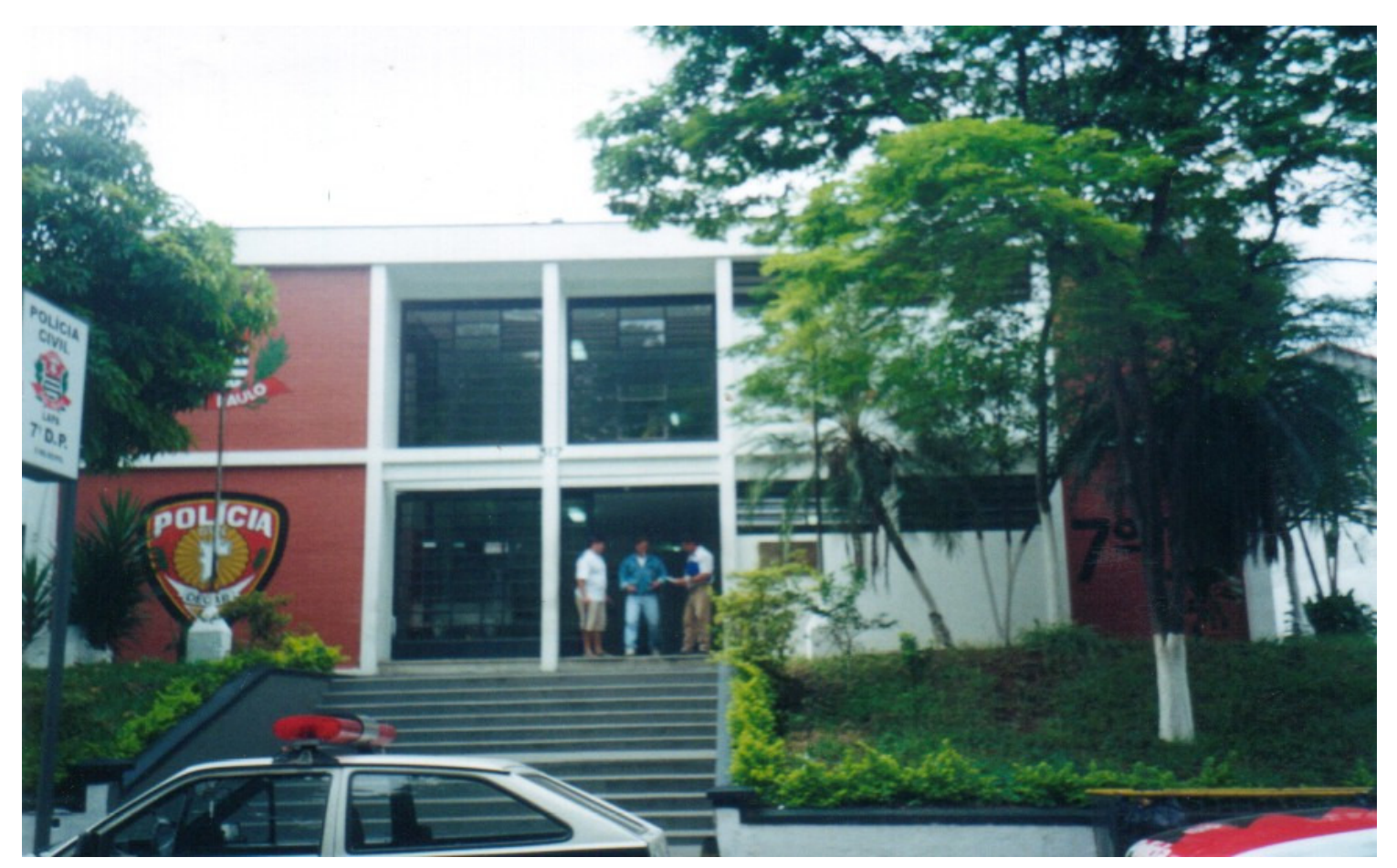



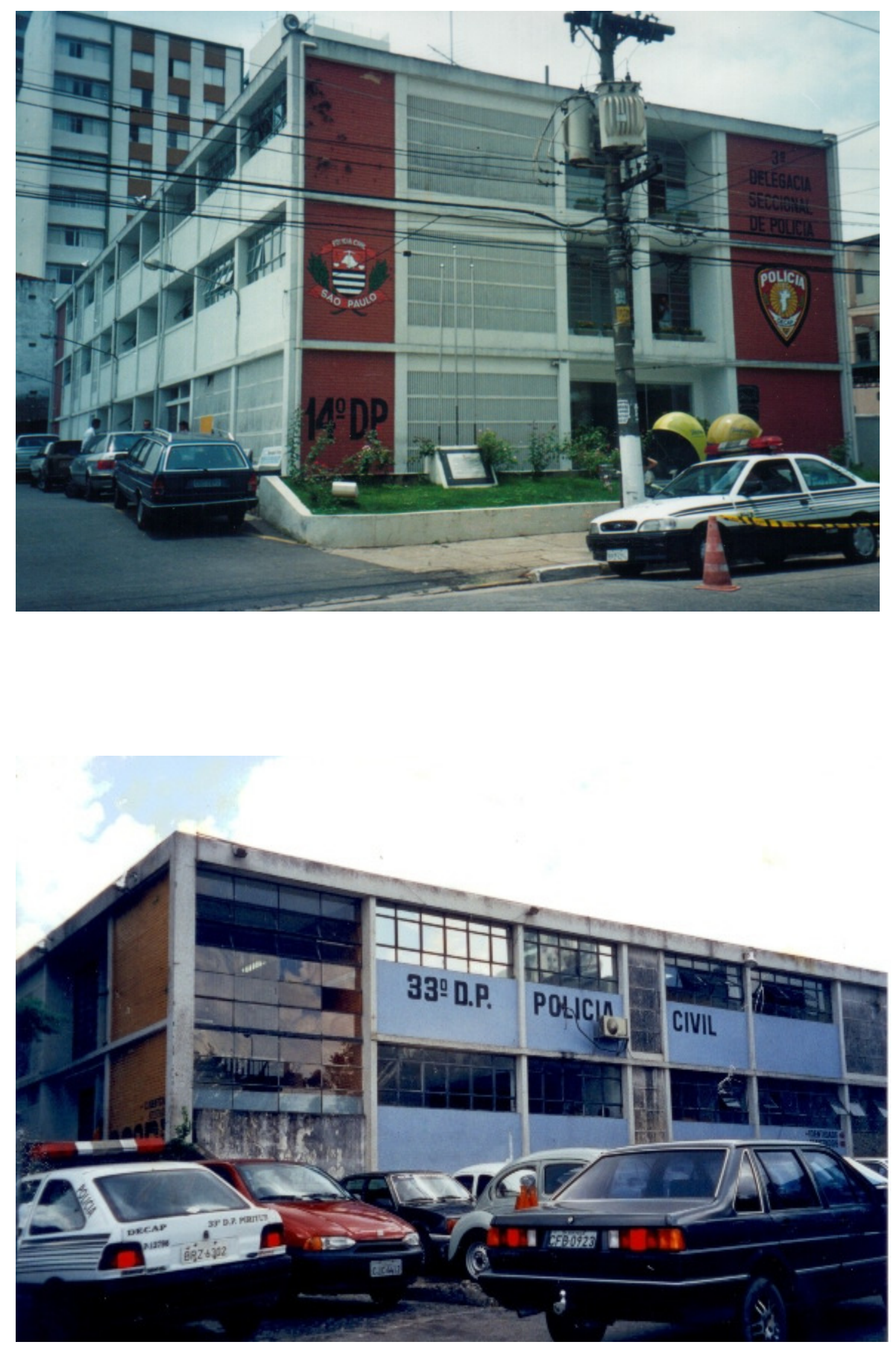

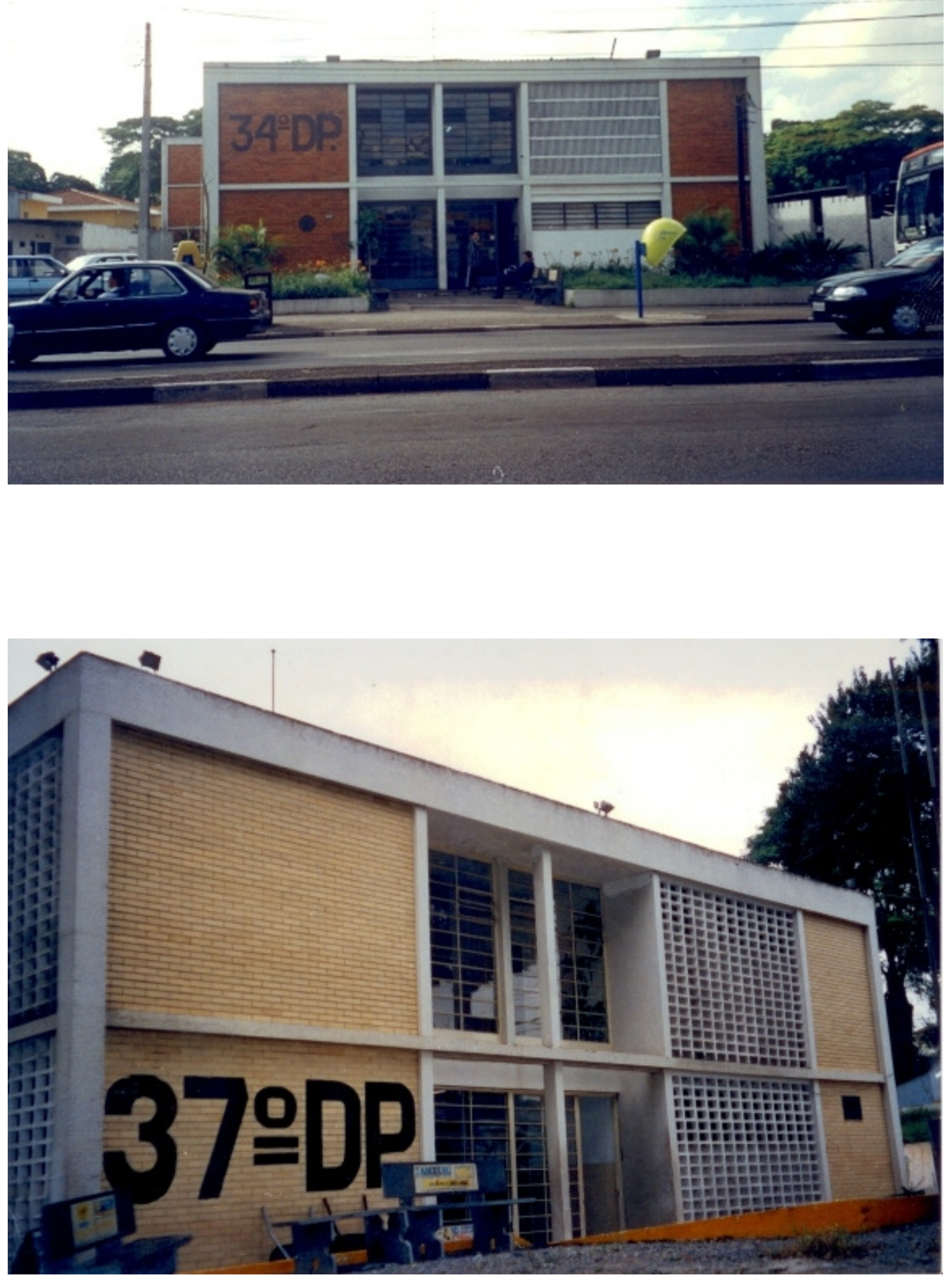

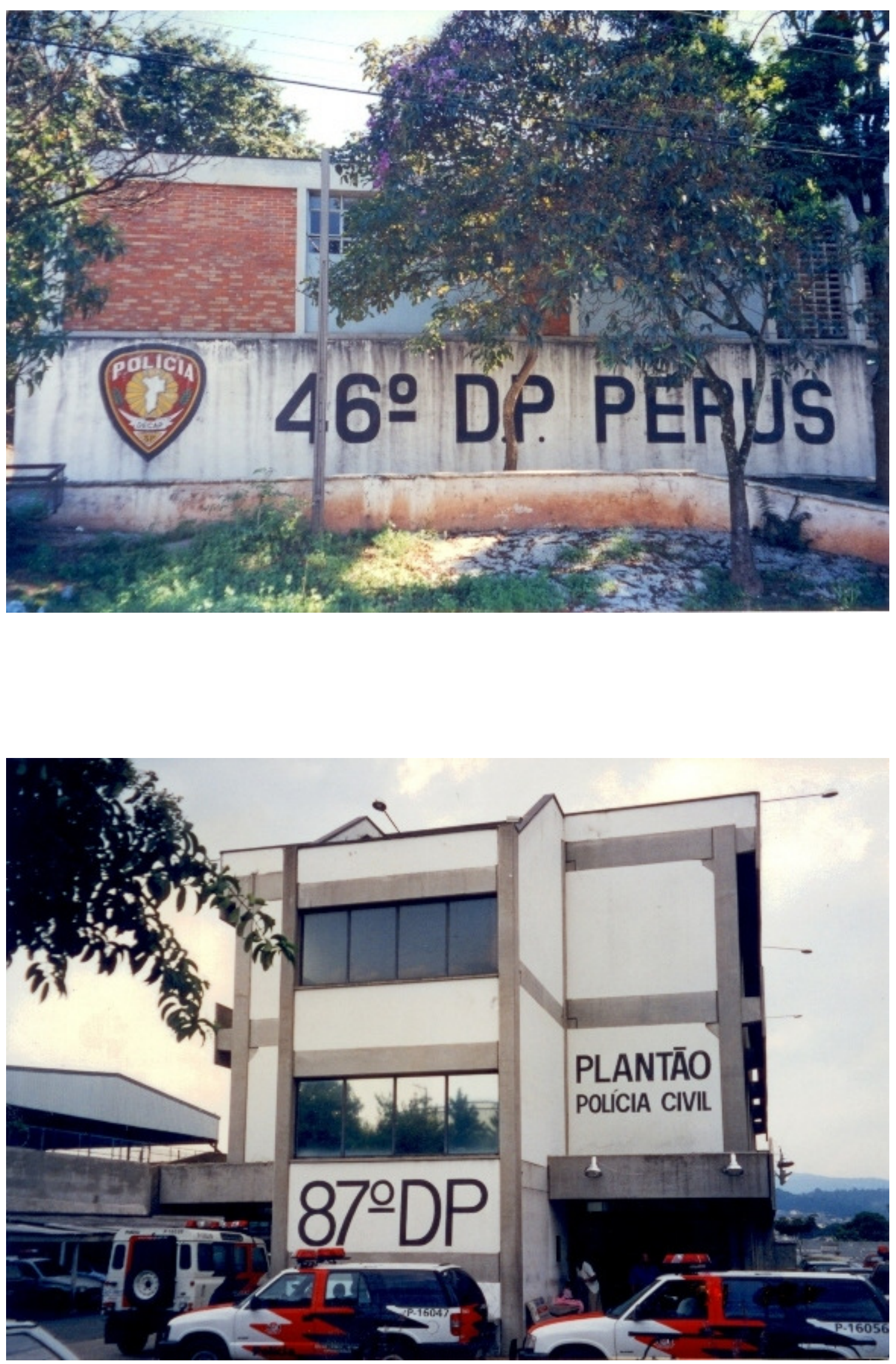

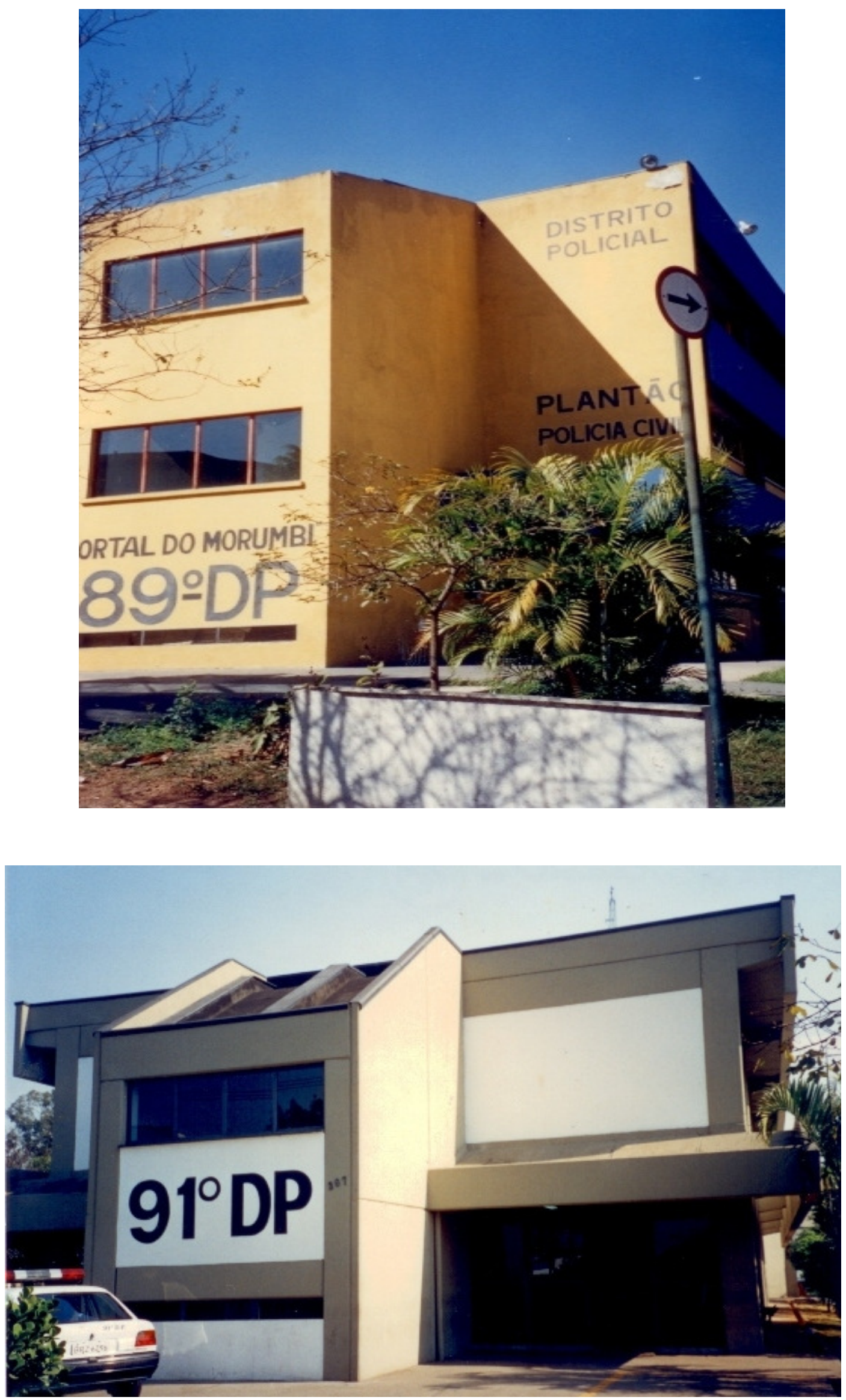
- A carceragem dos Distritos Policiais eram sujas, malcheirosas e superlotadas, com presos amontoados em condições subumanas. O calor era insuportável e o cheiro uma mistura de suor, urina, tabaco e falta de higiene. Em função disto, presenciamos alguns desmaios de presos durante nossa permanência nos Distritos Policiais. O pátio da carceragem era contornado por 2 ou 3 celas comuns, em cada lado. Pelas fotos de alguns pátios internos, pode-se ter uma idéia das péssimas condições carcerárias dos Distritos Policiais.

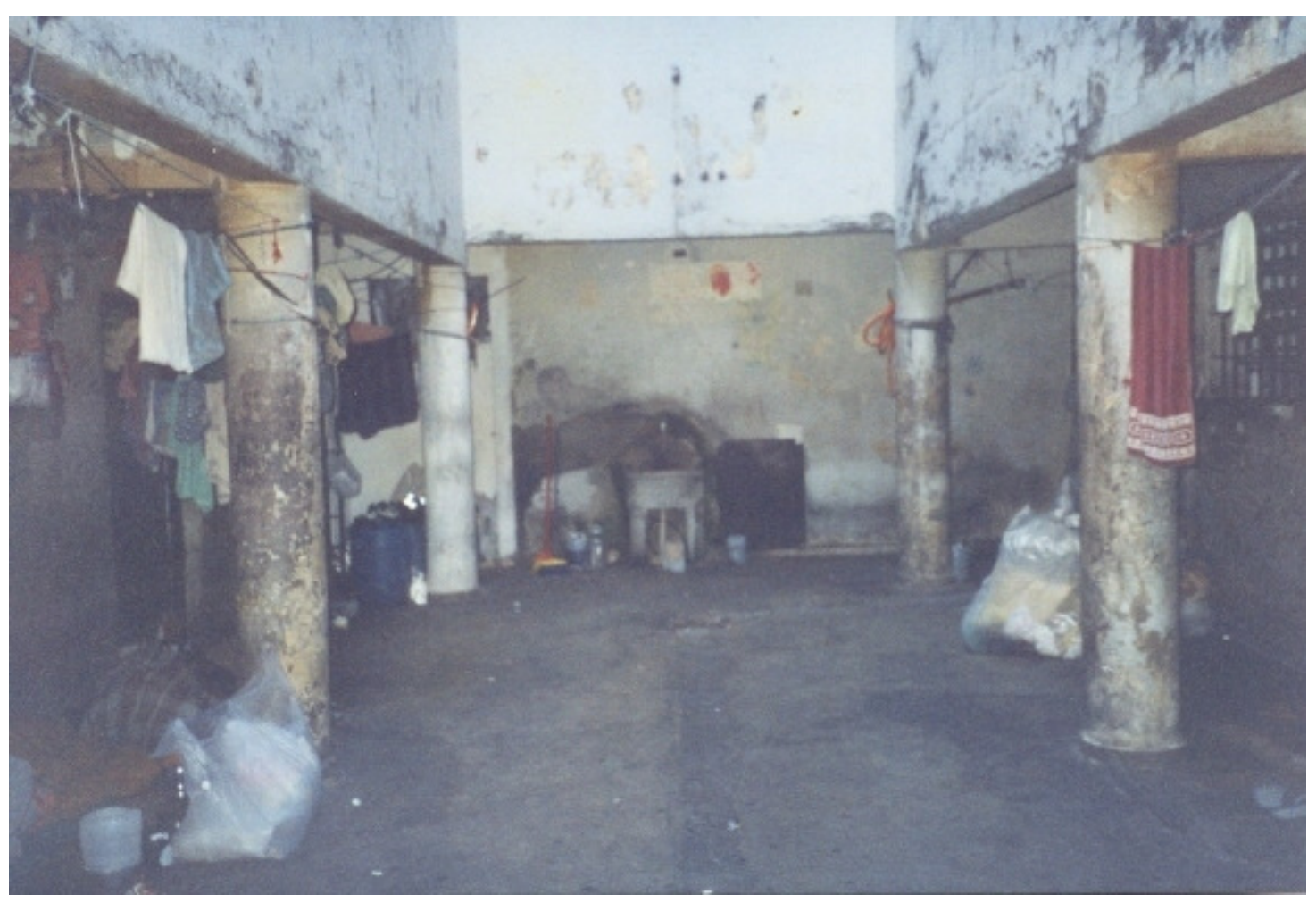



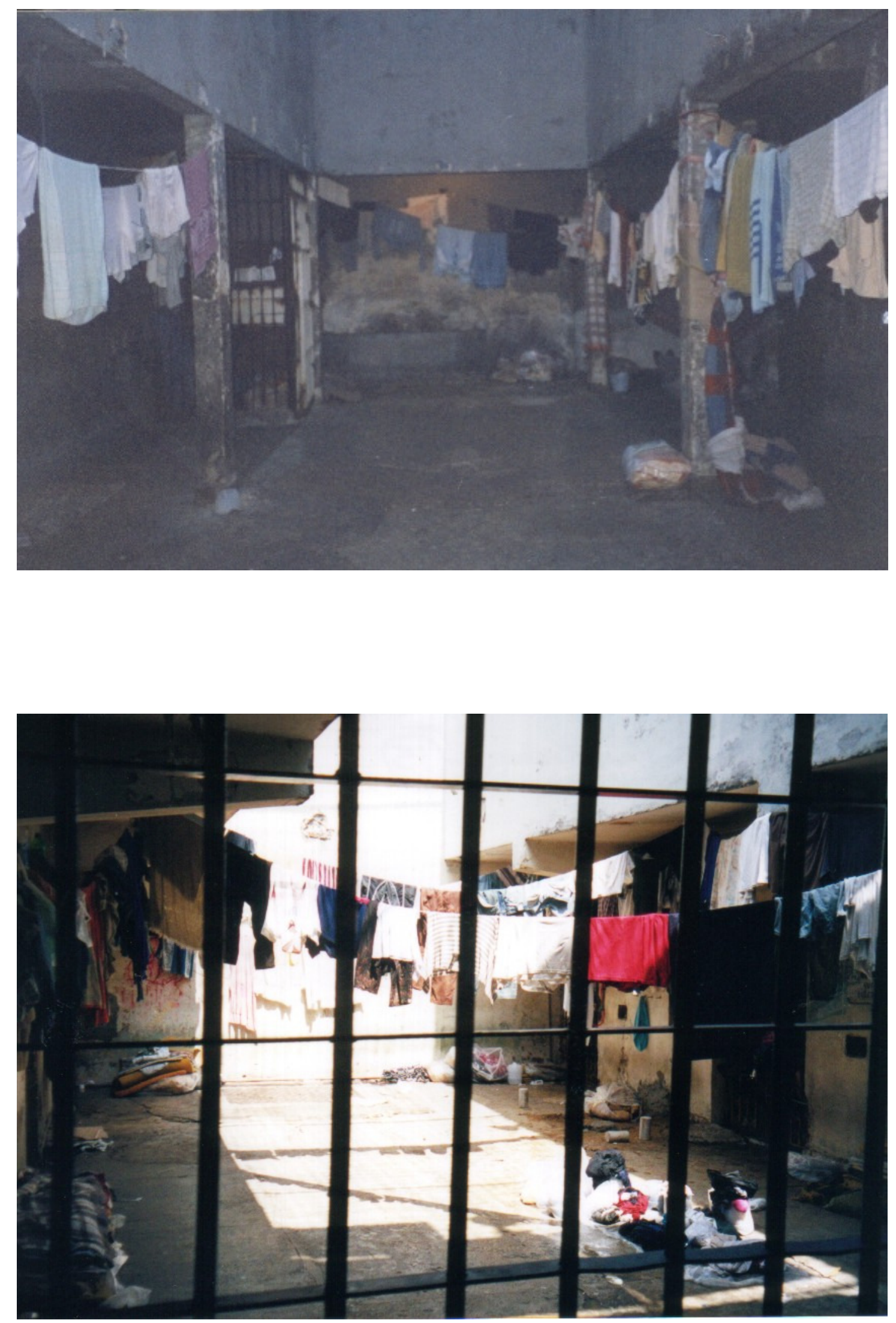

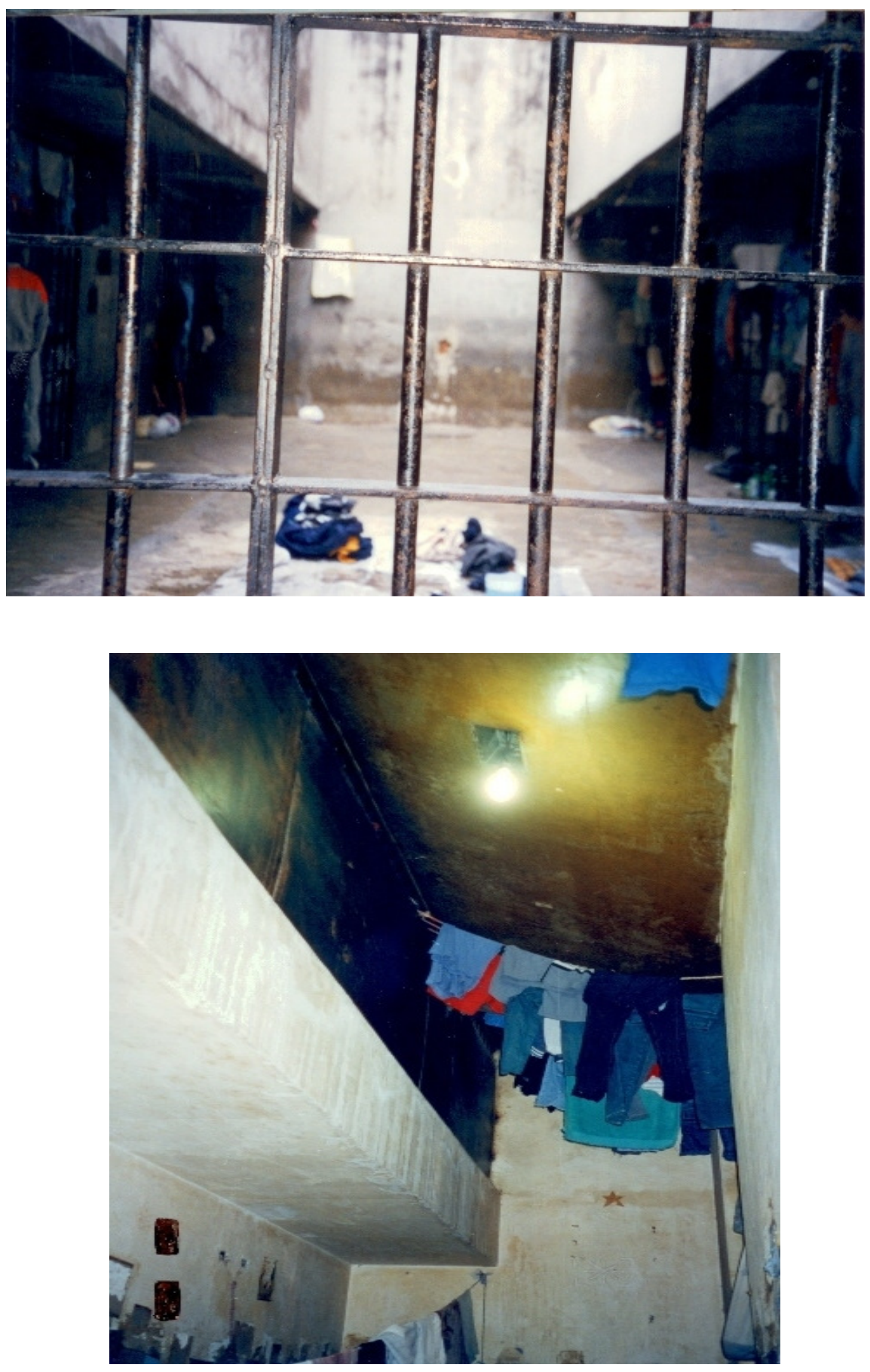
- As celas (ou xadrezes) abrigavam uma média de 30 presos, por isso, os detentos que dormiam no chão, deitavam-se em $\mathrm{J}$ (os pés no rosto do outro), 4 a 5 presos dormiam no banheiro, ao lado da latrina, e o restante improvisava redes feitas com cobertores amarrados nas grades da cela, em forma de $\mathrm{X}$ e em camadas até o teto. As 4 fotos seguintes, ilustram esta realidade.

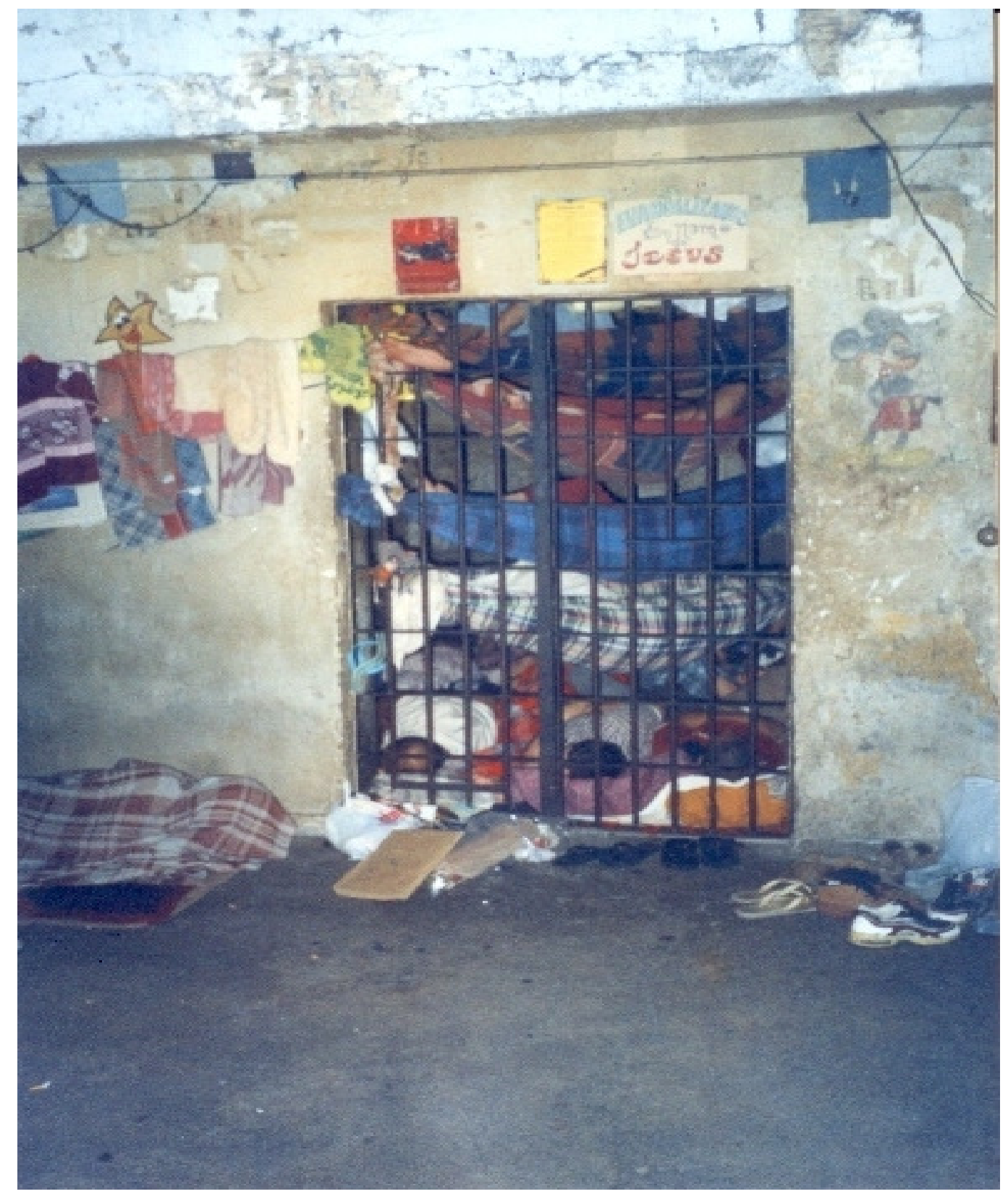



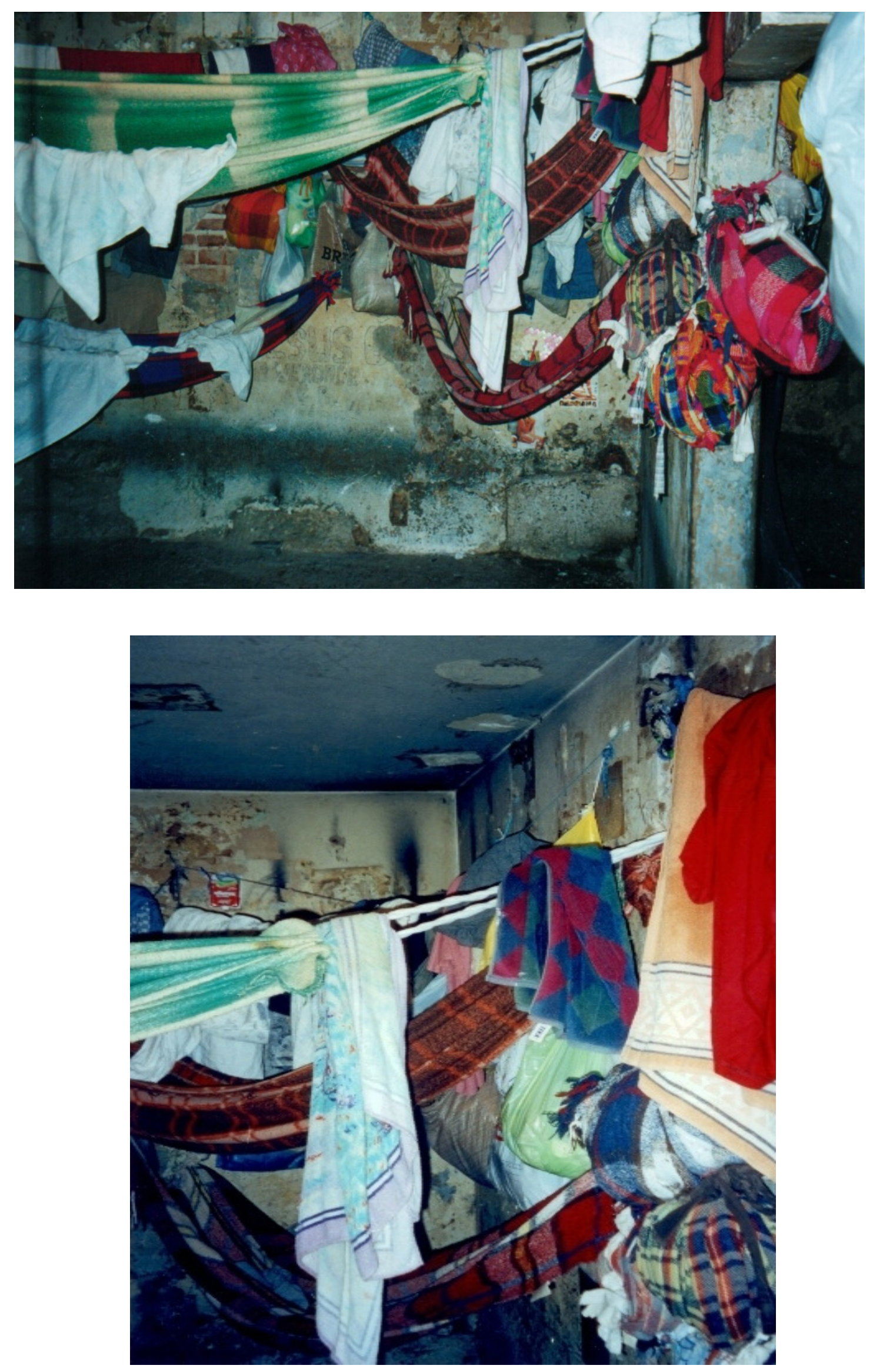


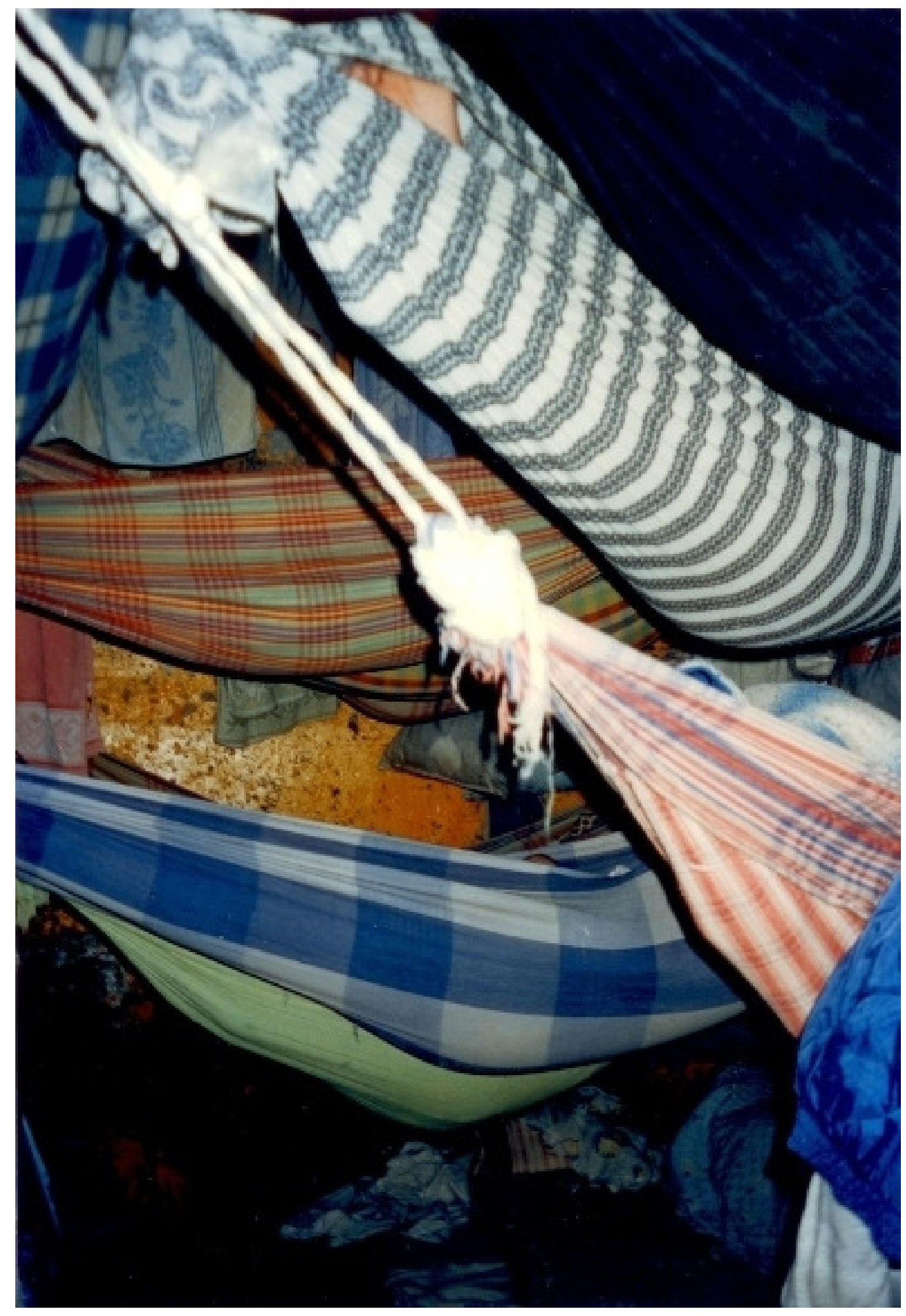


Em 2 Distritos Policiais as celas estavam sem grades, devido à rebeliões sucessivas. Nestes locais, muitos presos dormiam espalhados pelo pátio, melhorando o espaço dentro das celas. Apesar da aglomeração, observamos que em vários Distritos Policiais havia uma televisão e um ventilador em cada cela. Algumas fotos das celas mostram que os presos guardavam seus pertences em sacos plásticos pendurados na parede.

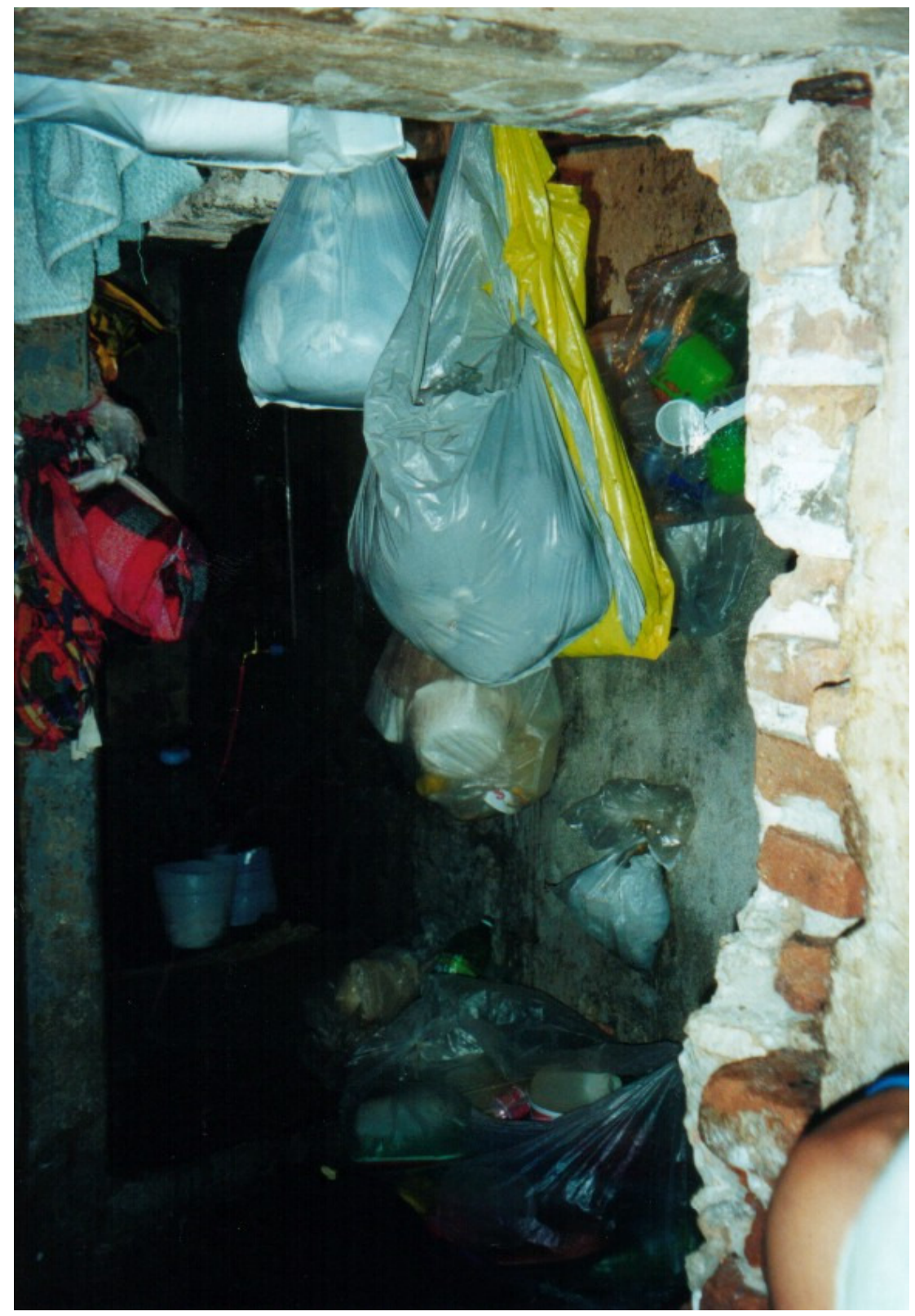



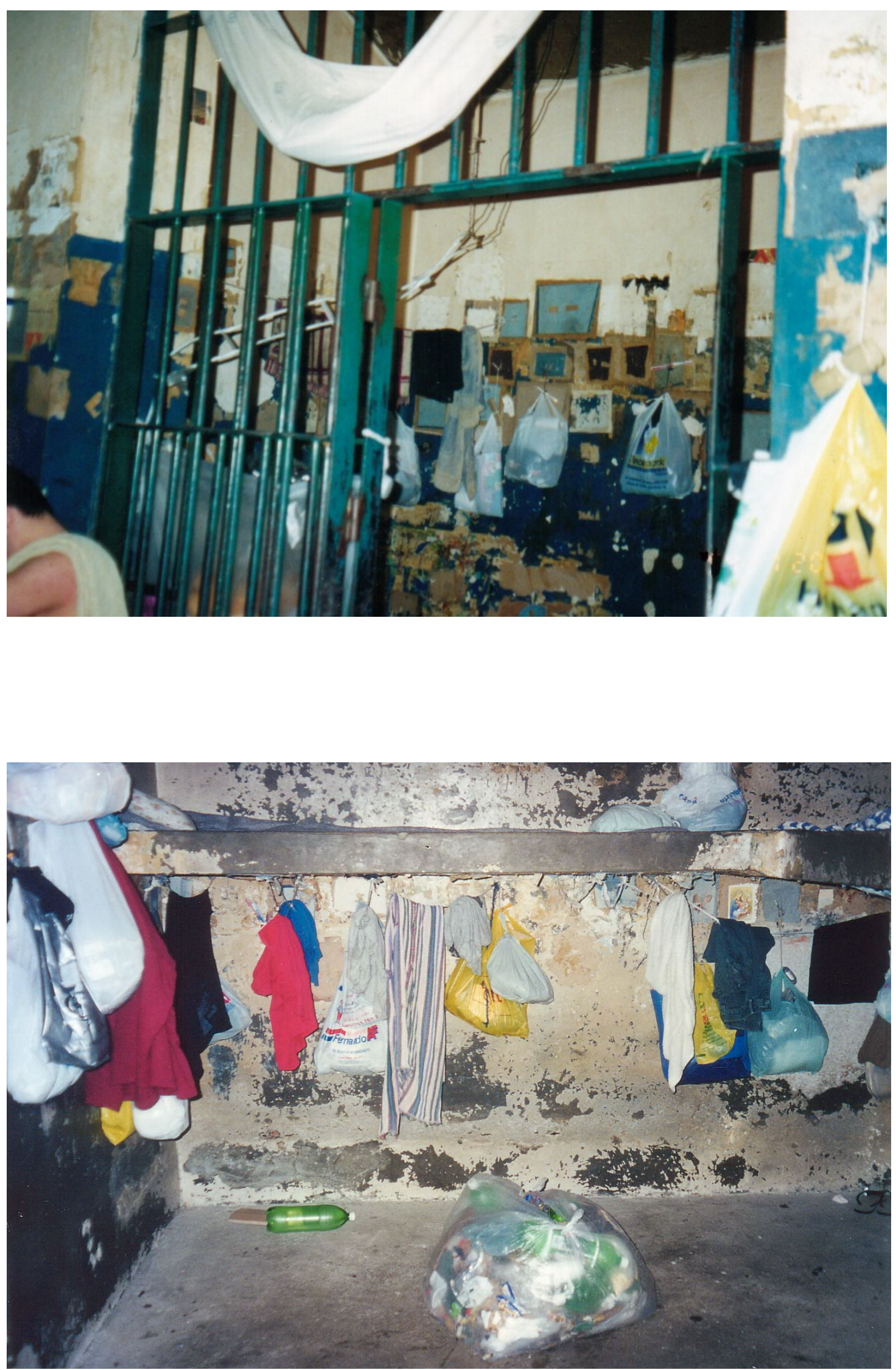

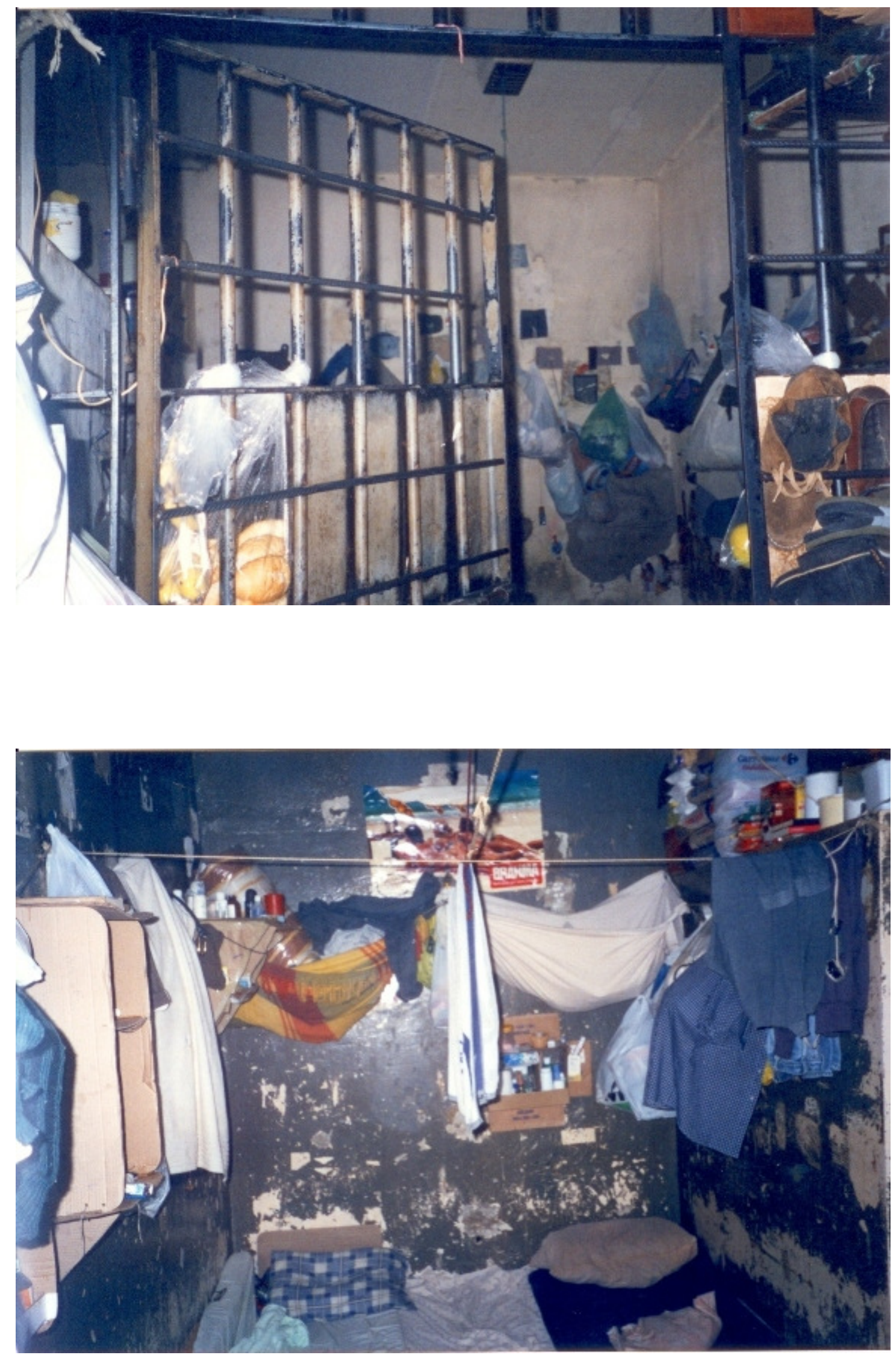

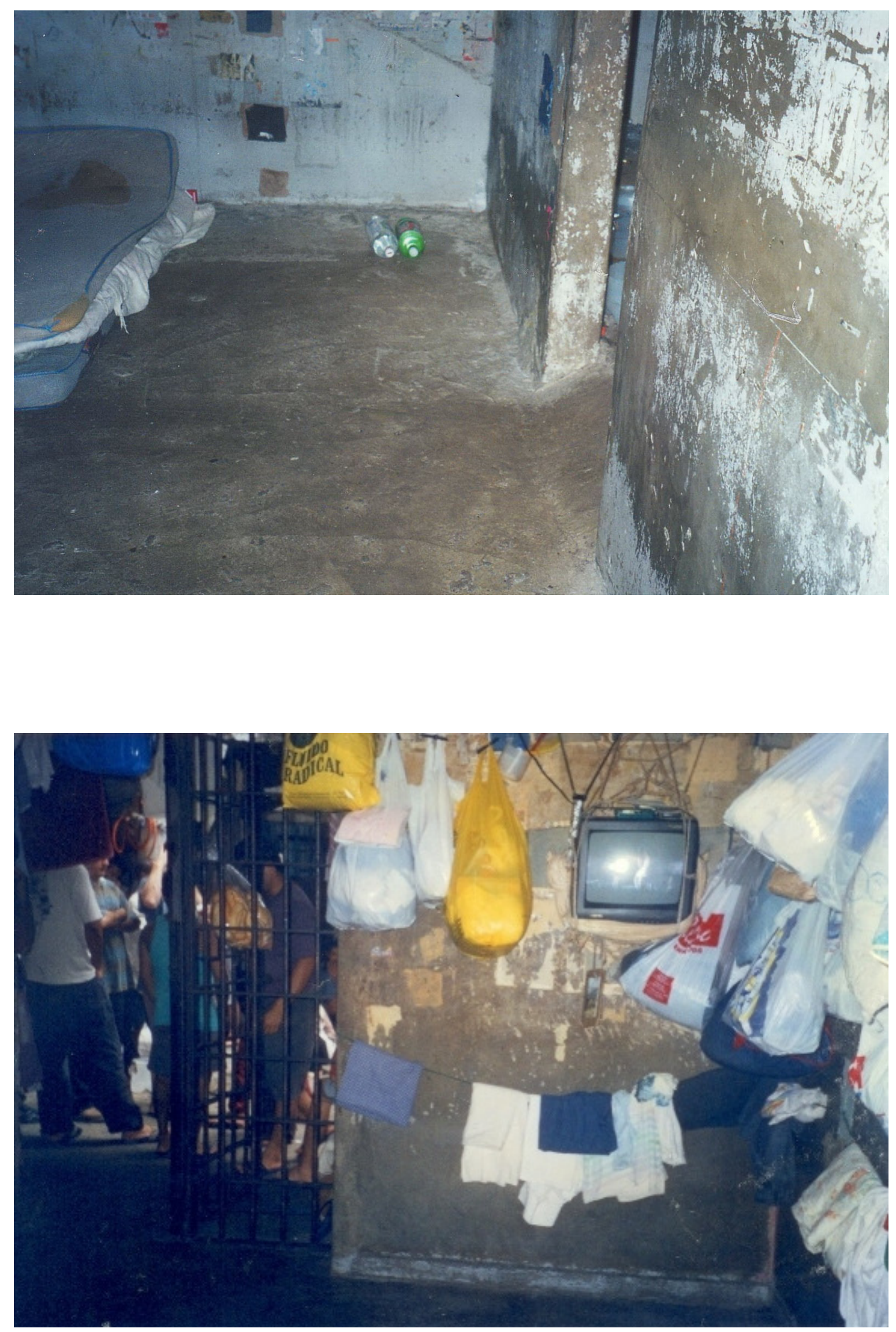

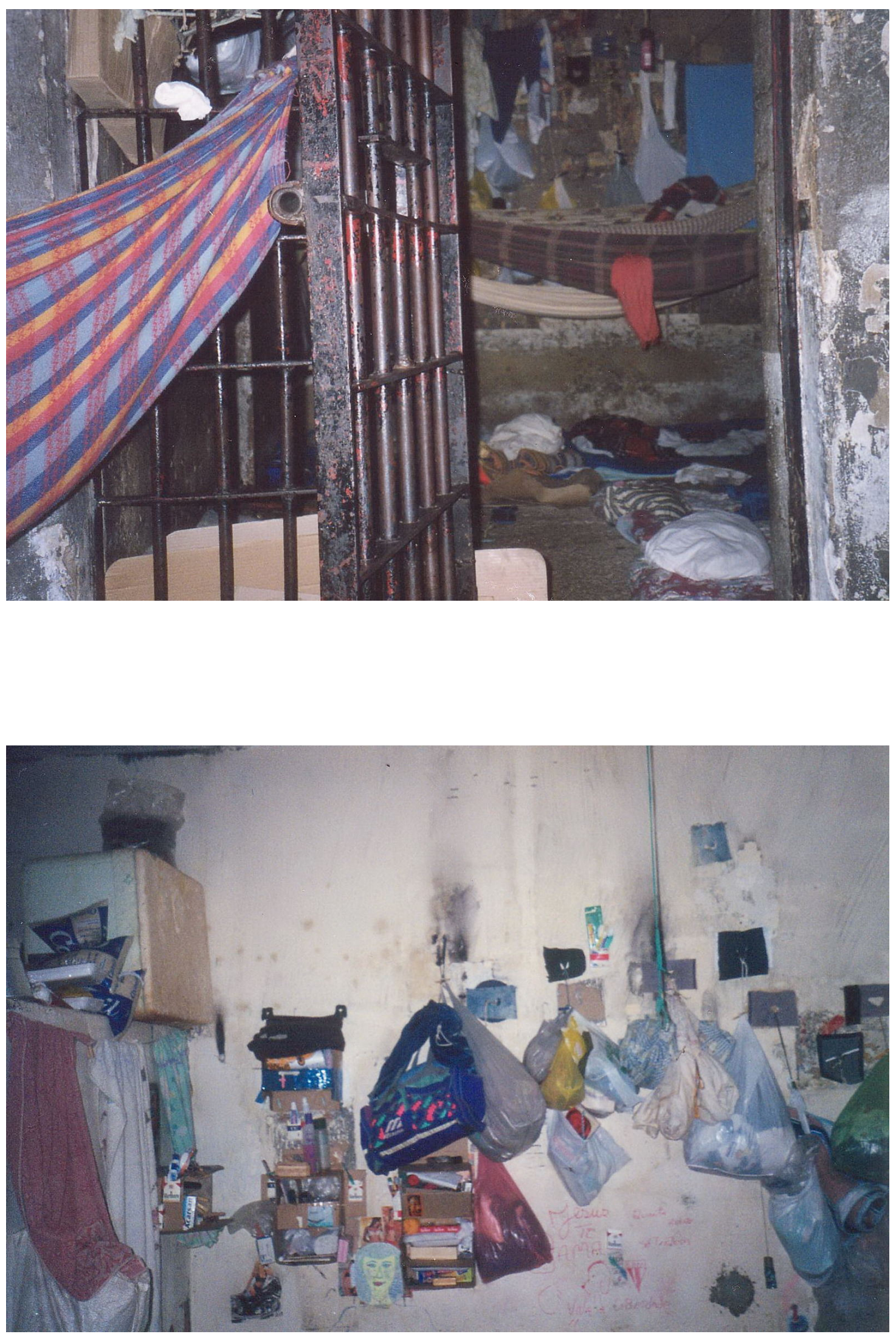
O lugar mais terrível para os detentos era o corró ou seguro, nos quais ficavam os presos jurados de morte, ou porque haviam cometido crimes hediondos, ou porque eram delatores que haviam notificado previamente as autoridades sobre uma tentativa de fuga, além dos travestis. Estes locais eram muito pequenos, superlotados e sem janelas, como podemos observar nestas fotos:

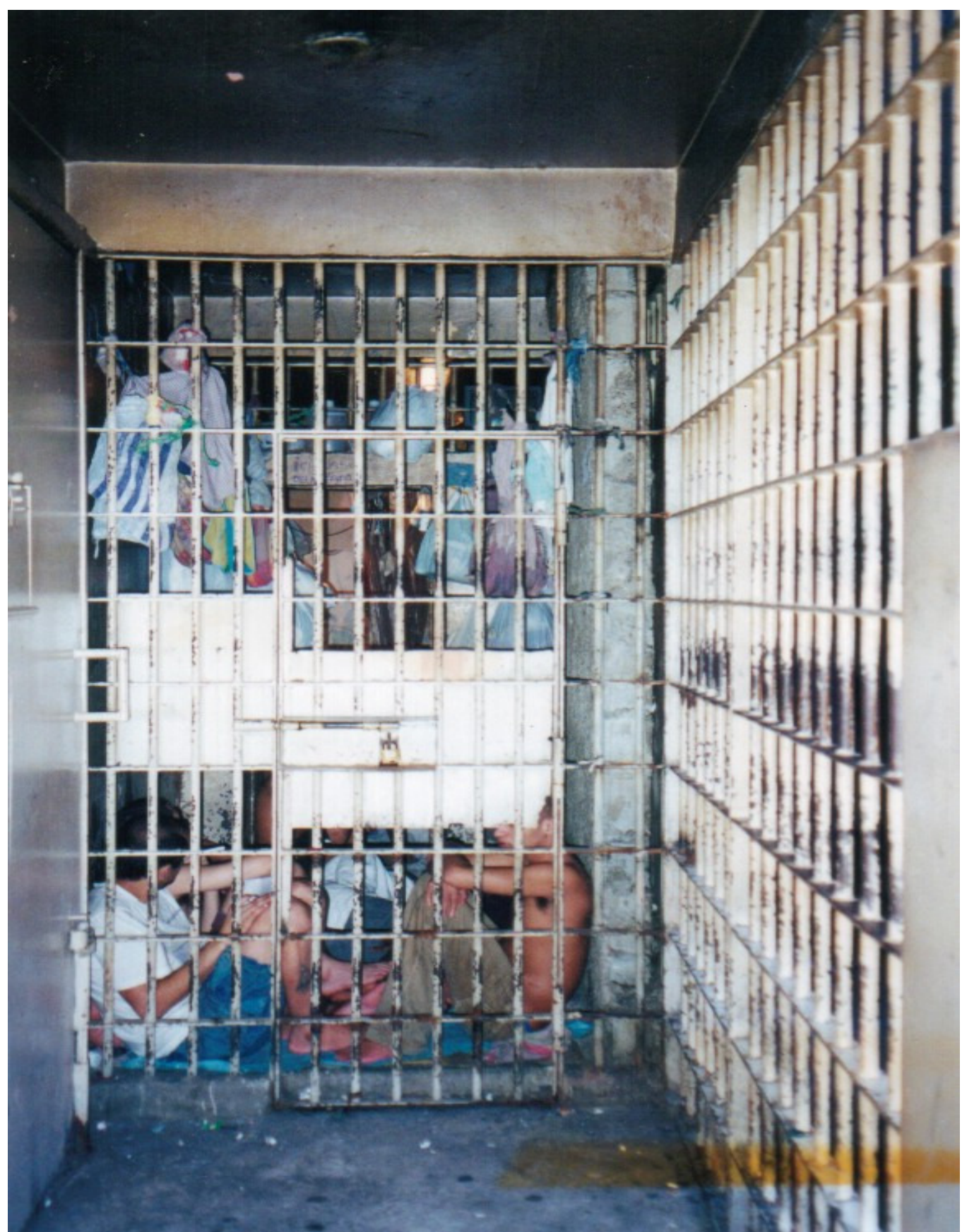




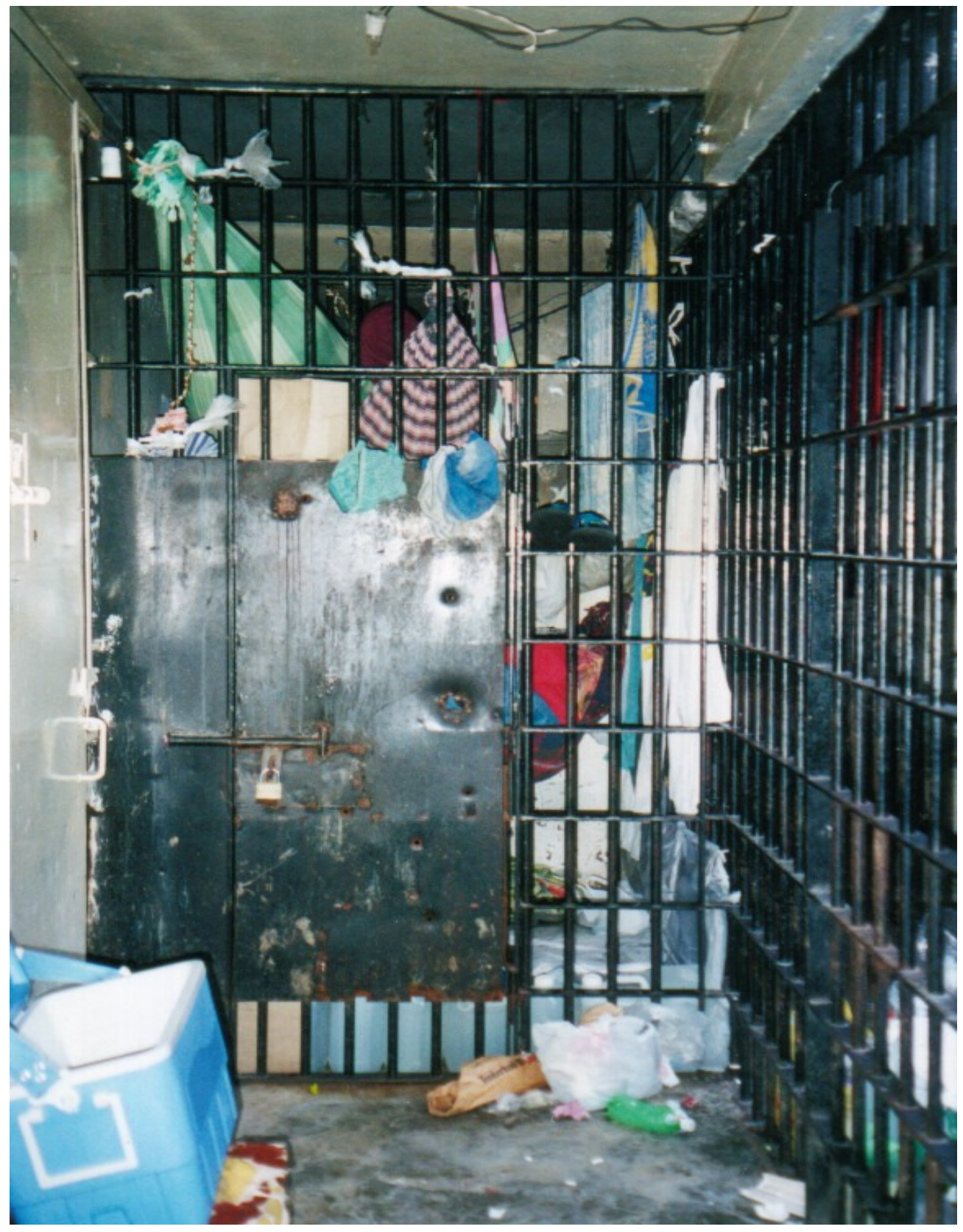

- Os banheiros ou "boi", eram buracos no chão, sem descarga e com forte cheiro de esgoto, por isso, os detentos colocavam um saco de areia sobre este buraco, para evitar o mau cheiro e a entrada de ratos e insetos. Os chuveiros, na maioria dos Distritos Policiais, eram apenas um cano na parede. 

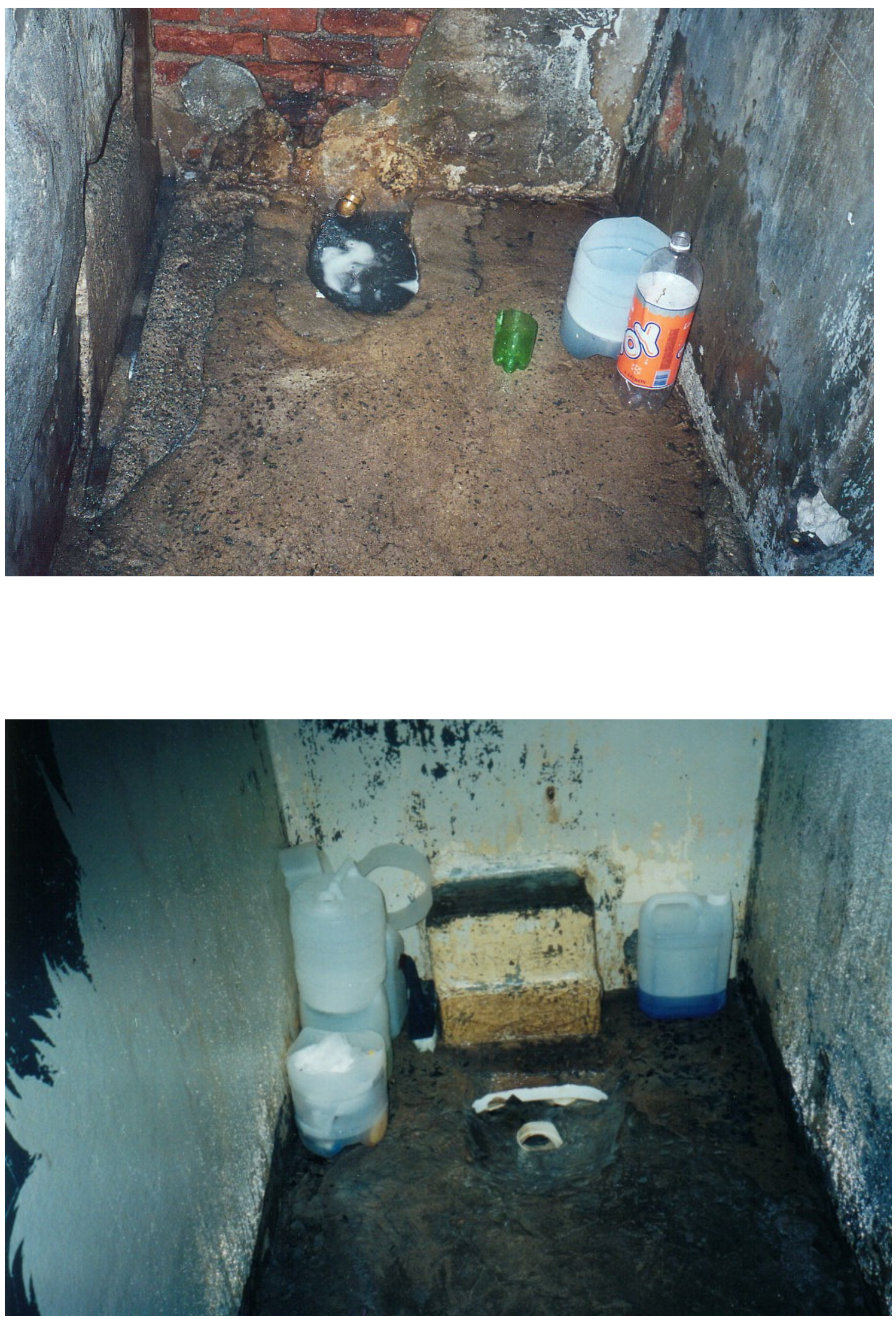

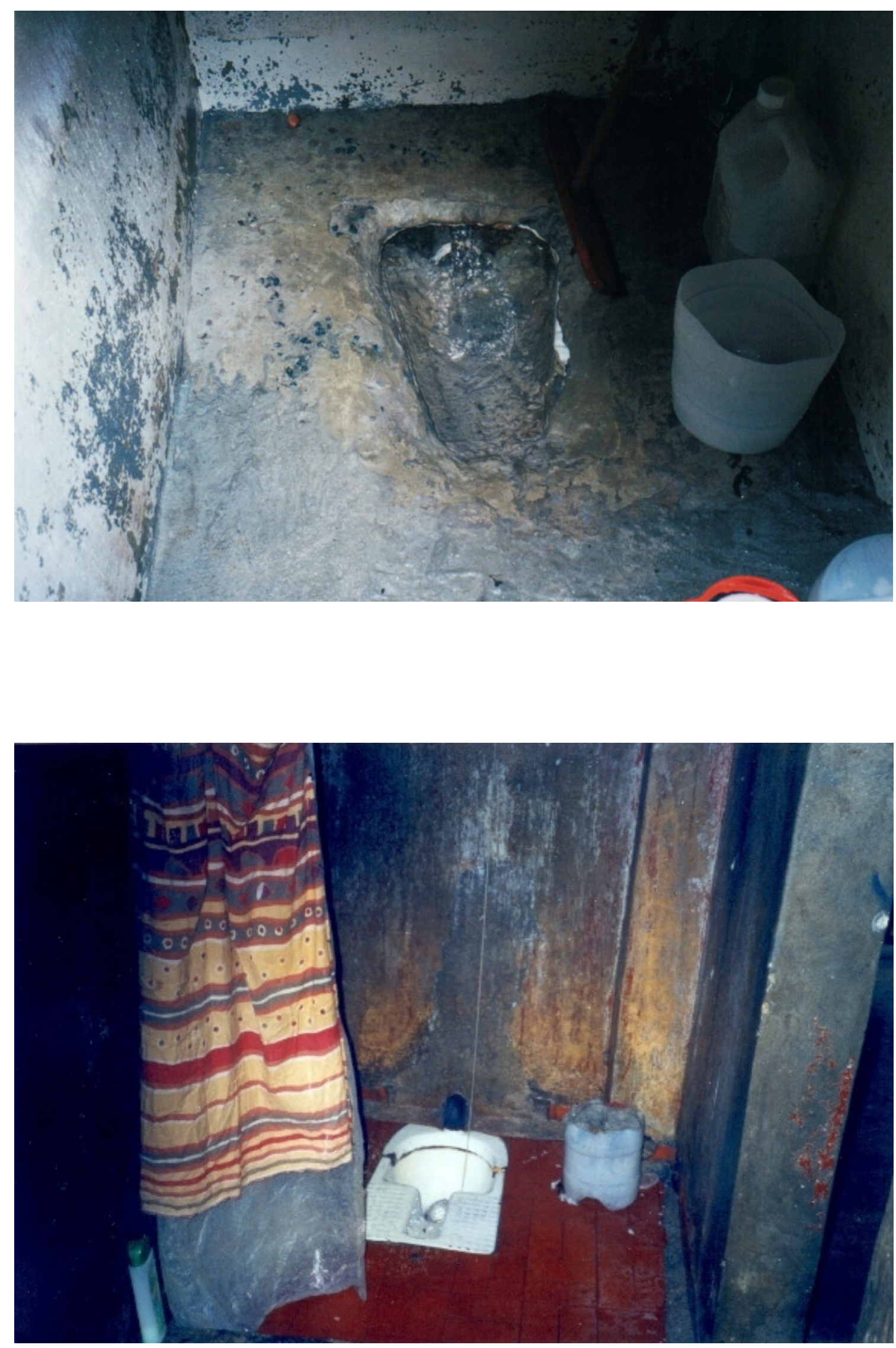

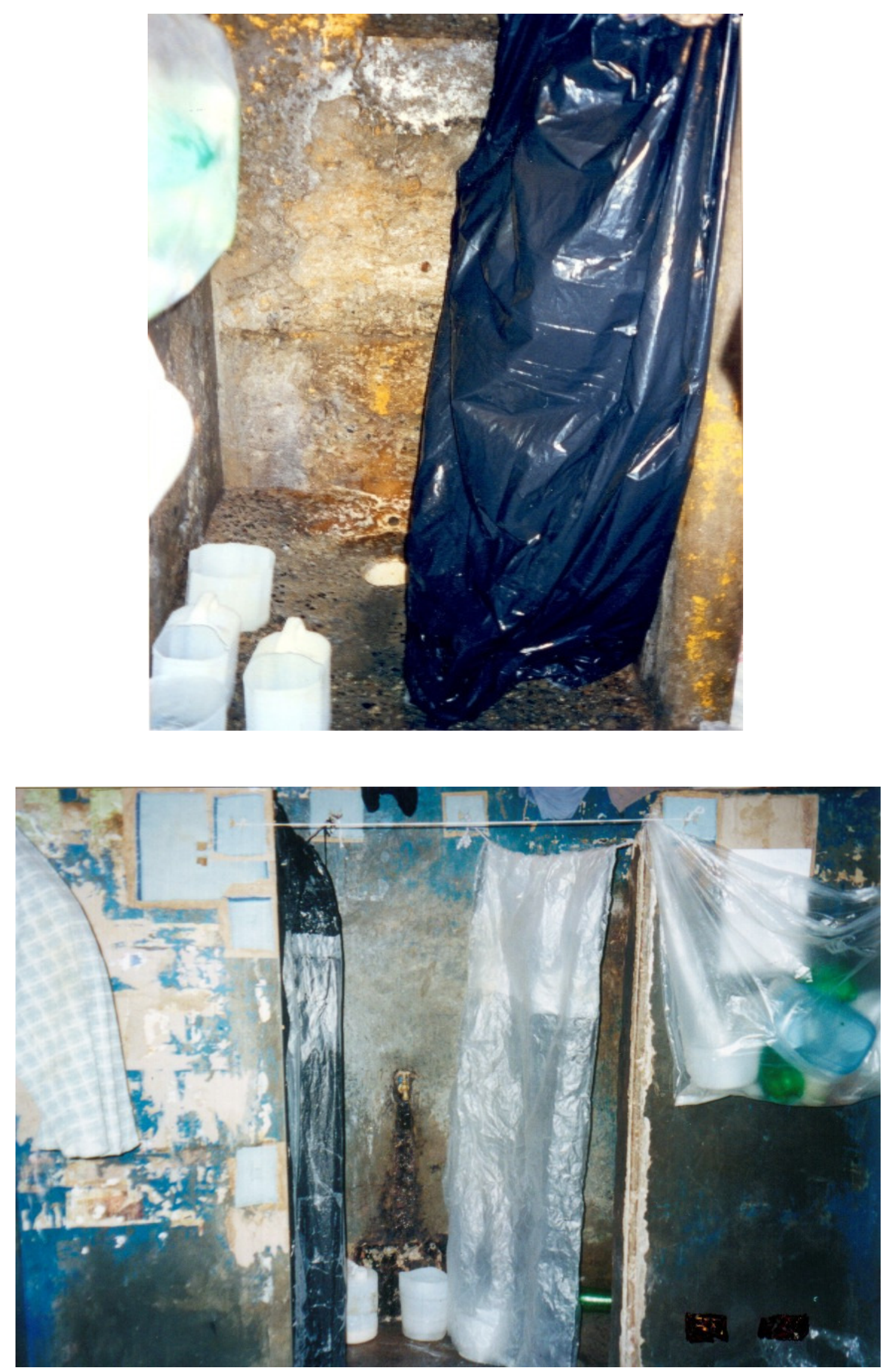


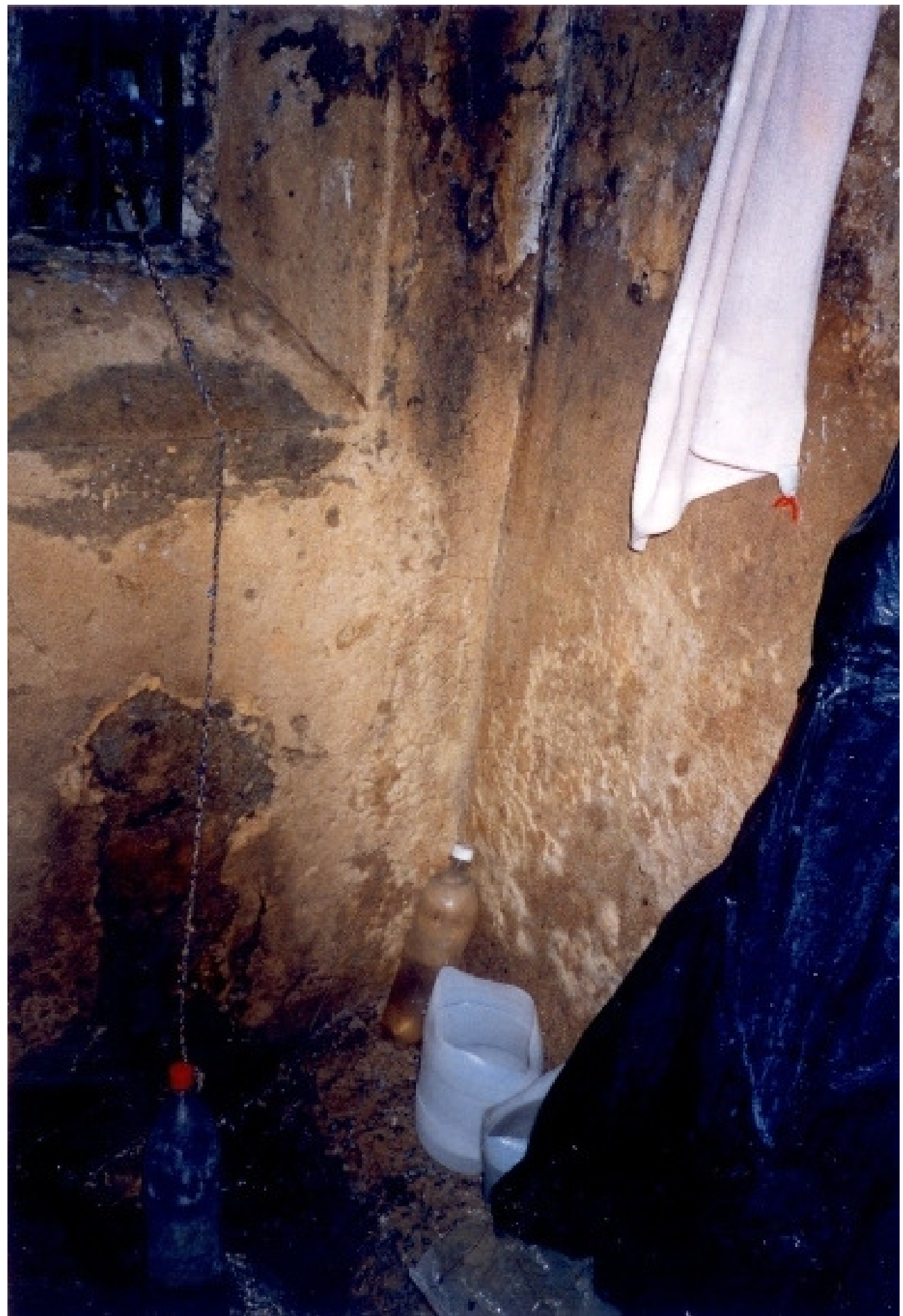

- A maioria das celas possuía uma pequena copa, conjugada ao banheiro, e nela, os detentos preparavam um "café preto" que sempre nos era oferecido. 

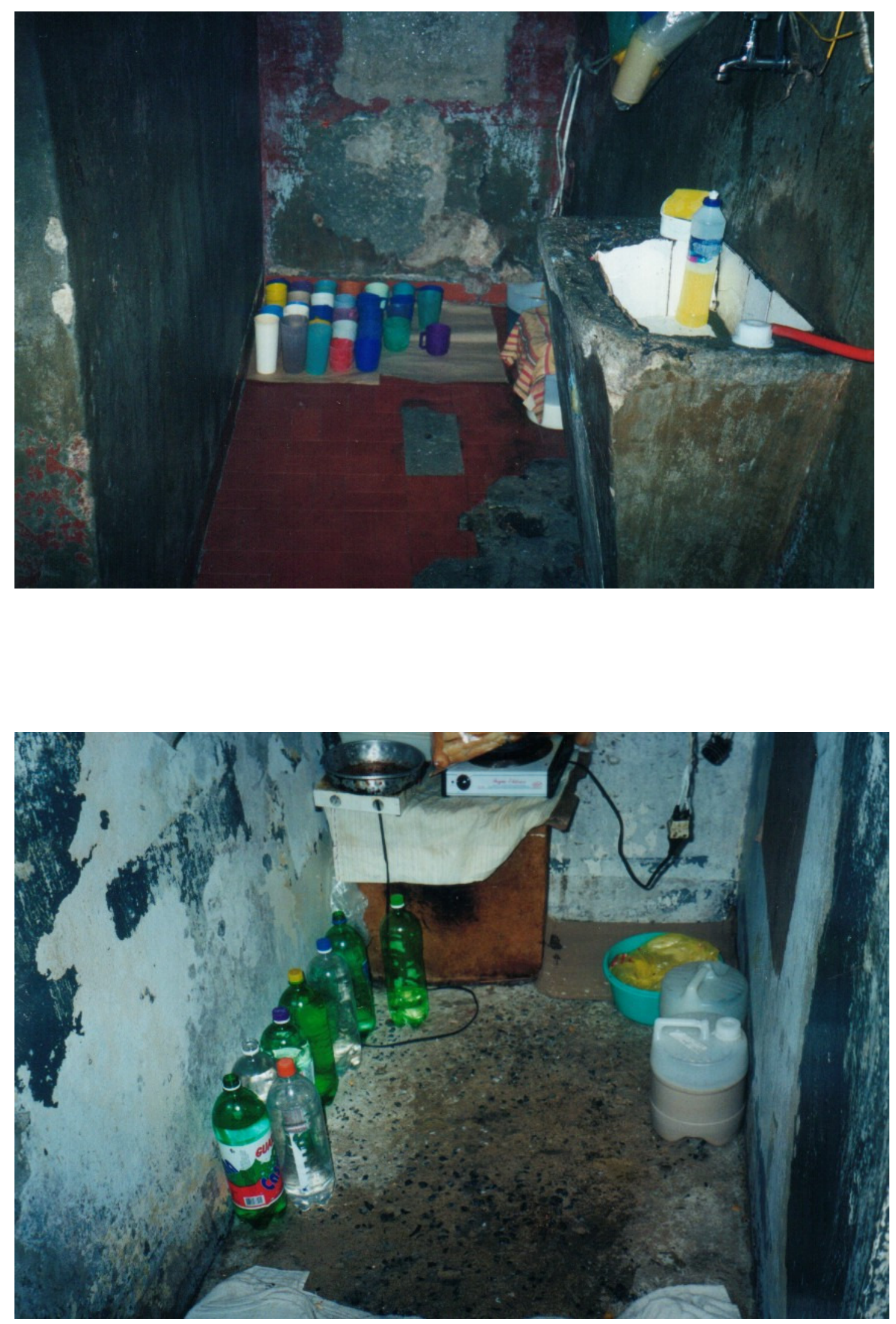


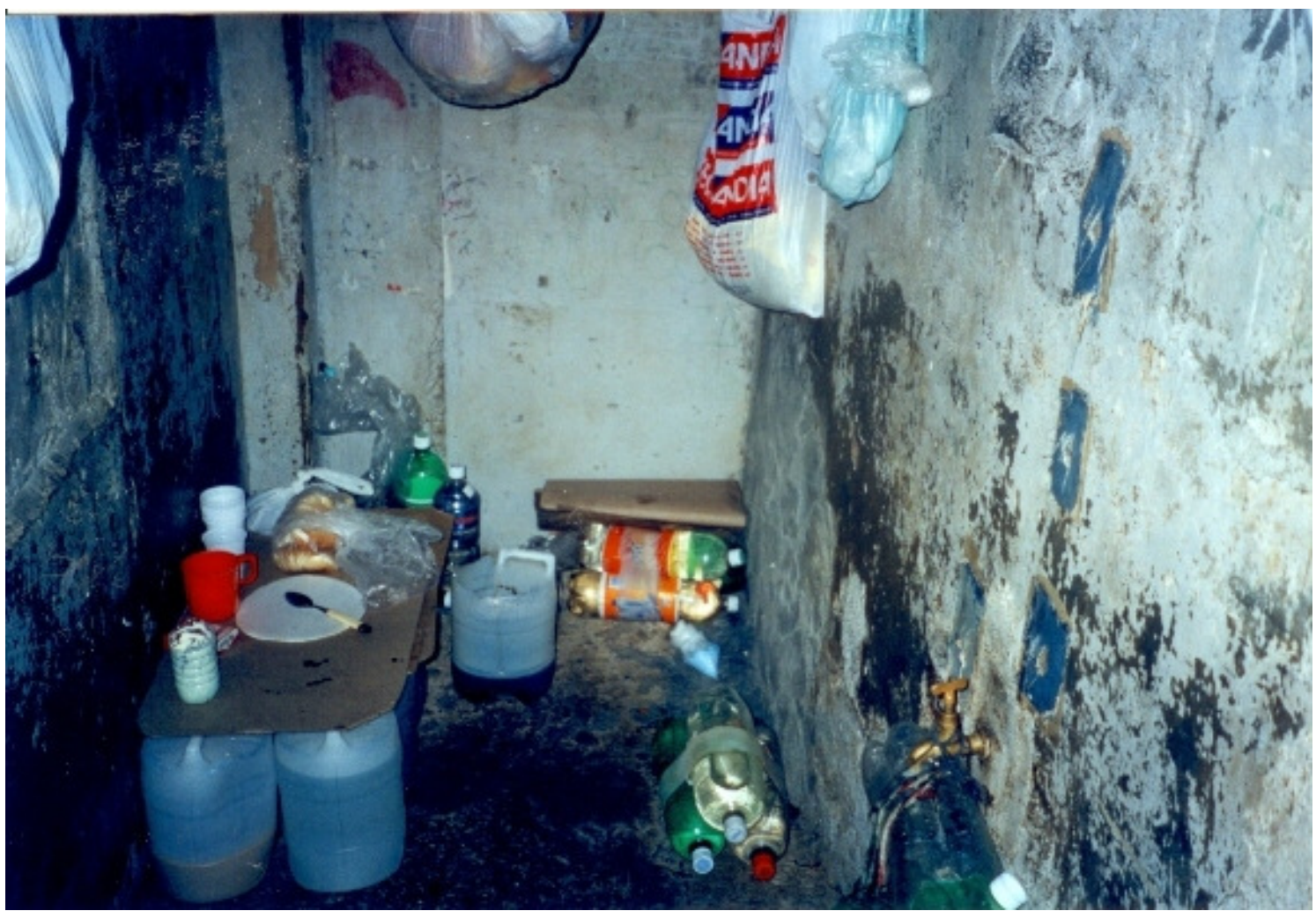

- Existia uma grande diferença entre os 8 Distritos Policiais que abrigavam homens e o único Distrito Policial feminino da Região. Neste local, apesar do calor, havia organização e limpeza. Todas as celas eram equipadas com camas ou colchões individuais, televisão e ventilador, chuveiro elétrico, sendo que na área comum havia geladeira, fogão e pia. As detentas estavam bem vestidas e maquiadas.

Este Distrito está apresentado separadamente, devido à sua peculiaridade. As fotos são de 2 celas, um armário para mantimentos, o chuveiro, o banheiro e as 2 áreas comuns. 

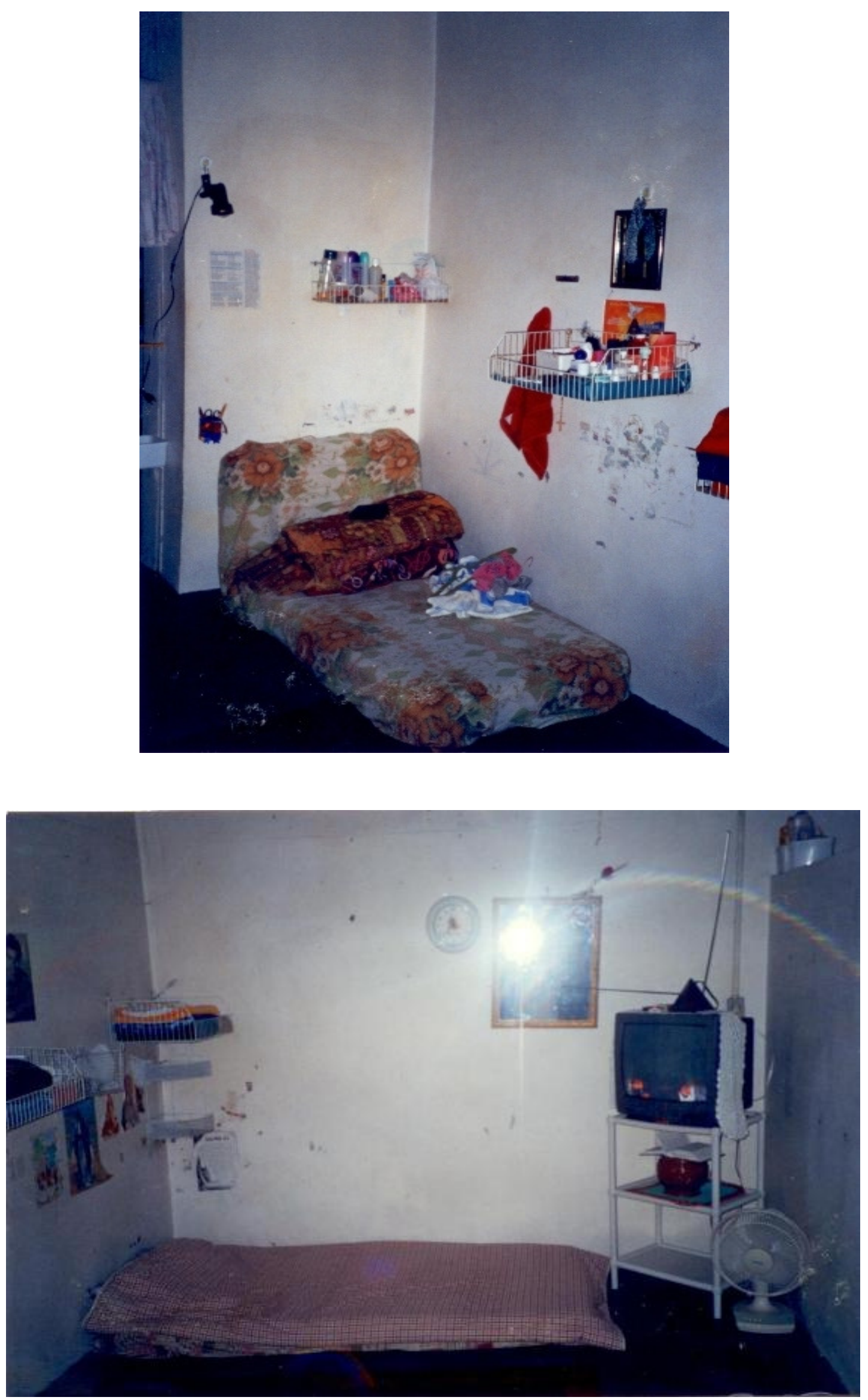

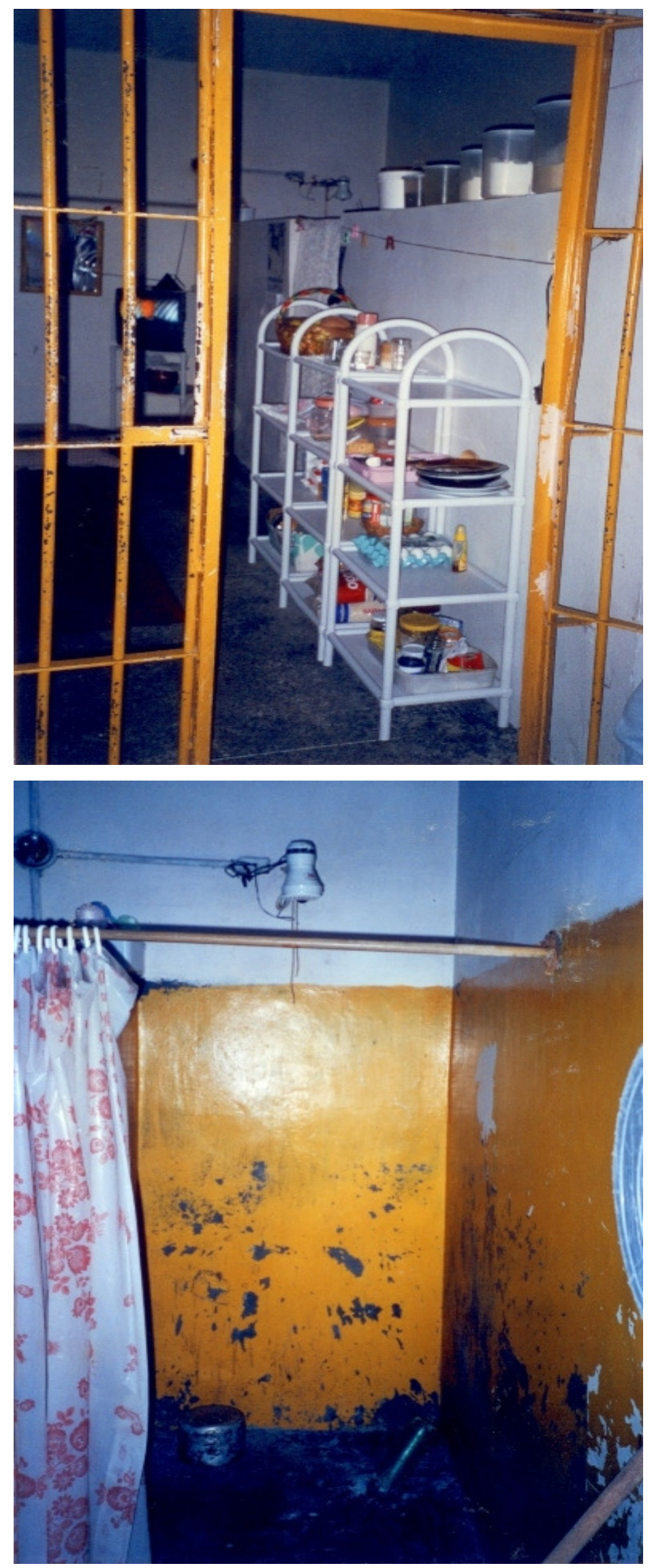

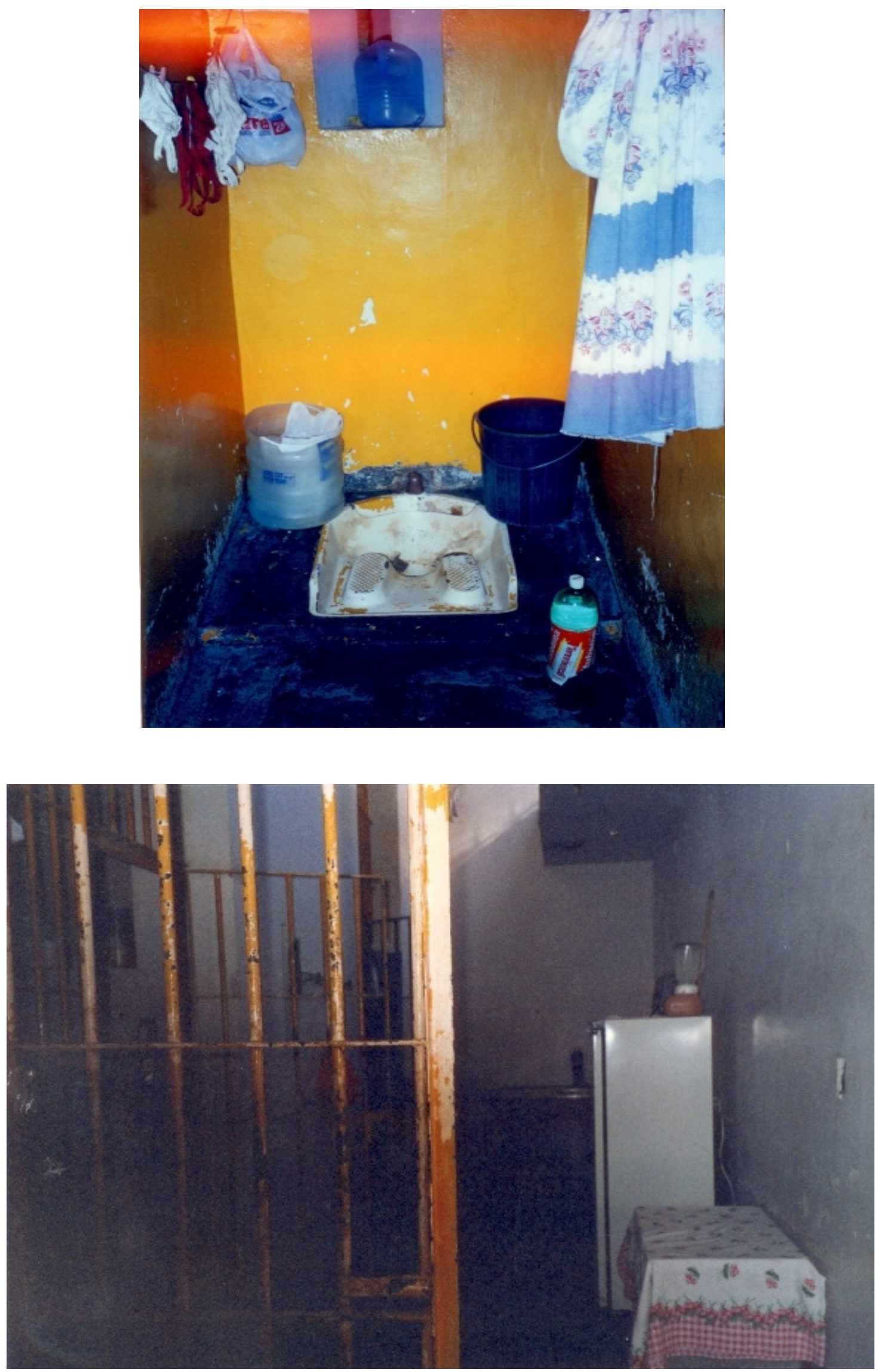


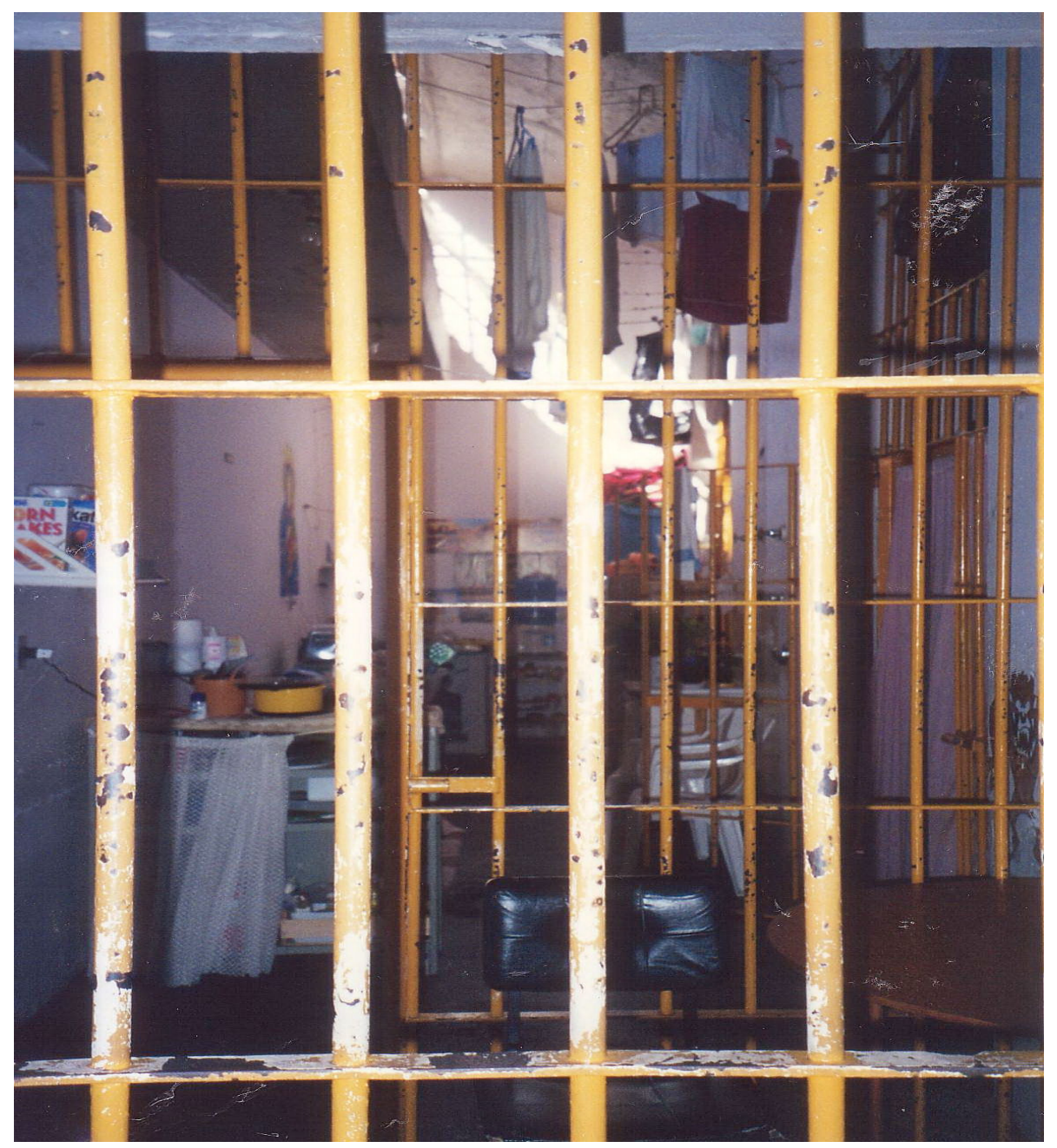

- Retornando aos detentos, devido à aglomeração e à falta de insolação, ventilação e higiene, as carceragens eram sempre úmidas. Observamos que a maioria deles sofria de escabiose, dermatites e freqüentes surtos gripais, demonstrando uma baixa resistência física e imunológica, provavelmente decorrente do stress do encarceramento, além de outros fatores. Estas condições favoreciam a transmissão e implantação de outras doenças, como a tuberculose. Os presos reclamavam muito de um pequeno besouro, chamado "muquirana", que se alojava em suas roupas e provocava uma coceira intensa na pele. Os detentos tinham dificuldades em obter medicamentos e/ou assistência médica.

Quando muito debilitados, dependiam de vagas no Hospital Penitenciário, constantemente lotado. Dificilmente eram aceitos em Pronto-Socorros por falta de policiais para fazer a segurança e pelo temor de resgate destes detentos por quadrilhas especializadas. 
- No $7^{\circ}$ DP - Lapa, havia 3 detentos com tuberculose resistente às drogas antituberculose, sendo que 2 eram provenientes de vários Presídios do interior do Estado de São Paulo e de outros Distritos Policiais, e 1 estava preso pela primeira vez. Eles permaneciam há mais de 15 dias em uma cela com outros 30 detentos por falta de vaga no Hospital Penitenciário, constituindo uma potencial fonte de infecção para a população carcerária daquele local e dos outros Presídios pelos quais haviam passado, para os funcionários e policiais do Distrito Policial, e para os familiares que os visitavam semanalmente.

- As carceragens dos Distritos Policiais recebiam visitas um dia por semana, durante 2 a 4 horas. Os visitantes se limitavam a parentes, cônjuges ou companheiras dos detentos.

Durante a visita semanal, os familiares eram revistados e só podiam levar o "jumbo", que consistia em uma sacola com mantimentos e artigos de higiene. As visitas conjugais ou "íntimas" eram permitidas na maioria dos Distritos Policiais, pois amenizavam as tensões entre os detentos, melhorando a atmosfera dentro da prisão.

Sem as suas famílias, os detentos não teriam apoio material, extremamente necessário na carceragem, como dinheiro, colchões, roupas de cama, cobertores, cigarros, vestimentas e produtos de higiene pessoal. A luta por espaço e a falta dessas provisões básicas, resulta na exploração entre os presos. Portanto, aquele que não tem dinheiro ou apoio familiar é vítima dos outros detentos. Por este motivo, um dos principais meios de controle sobre os detentos, era a ameaça de transferência para prisões mais distantes de suas famílias.

- Em um dos Distritos Policiais, durante a visita íntima, um preso desavisado abriu a cortina improvisada, que ocultava a cama na qual estava um casal. No dia seguinte, os policiais encontraram no pátio uma das mãos (a que abriu a cortina) e o coração deste detento.

Este fato aconteceu, porque os detentos praticavam um rígido "código de ética". Eles não toleravam desrespeito aos seus familiares durante a visita, estupradores (porque a maioria deles, segundo o prontuário, estuprava filhas ou sobrinhas), assassinos de familiares, presos que cometiam outros crimes hediondos e 
principalmente os presos delatores. Por este motivo, essa "classe" de detentos, estava confinada nos "corrós" ou "seguros" das Delegacias.

- Cada DP possuía um líder entre os presos, o qual recebia proteção de outros detentos, que se revezavam a cada 8 horas, durante 24 horas. Os líderes que pertenciam ao PCC (Primeiro Comando da Capital) usavam pulseiras bordadas com a seguinte inscrição: “15-3-3 - 100\% ódio”, significando P (15 letra do alfabeto, excluindo-se a letra k), e 2 vezes $\mathrm{C}$ ( $3^{\mathrm{a}}$ letra do alfabeto).

- Muitos detentos eram tatuados. Quando perguntamos o significado das tatuagens, obtivemos várias respostas, como por exemplo: alguns se tatuavam na prisão para serem aceitos pelos companheiros, outros para mostrarem que pertenciam à determinadas facções criminosas e sentiam-se orgulhosos deste fato, e outros ainda, para impor respeito, uma vez que determinadas tatuagens os identificavam como presos de alta periculosidade.

Presenciamos o fechamento de túneis que haviam sido escavados para fugas. Havia a constante preocupação de não deixarmos potes vazios de escarro nas mãos dos detentos, justamente para evitarmos a confecção desses túneis. Nossa lista de coleta diária era conferida exaustivamente, para que nenhum pote ficasse na carceragem.

- Os detentos também aproveitavam nossa presença para pedir medicamentos e material para curativos, além da postagem de cartas para os familiares. Quando havia uma tentativa de fuga nos Distritos Policiais, os detentos sofriam algumas restrições, como a proibição de enviar e receber correspondências e cancelamento das visitas. Quando uma fuga fracassava, geralmente, havia uma rebelião.

- Para o bom andamento da pesquisa, tínhamos que chegar muito cedo em respeito aos horários da alimentação dos detentos, pois caso contrário a cadeia "virava", ou seja, eles se rebelavam. O local do nosso trabalho, as "viúvas", eram totalmente gradeadas, para não termos contato físico com os detentos. Nela os advogados e policiais também se comunicavam com os presos. Estas 2 fotos são das "viúvas": 


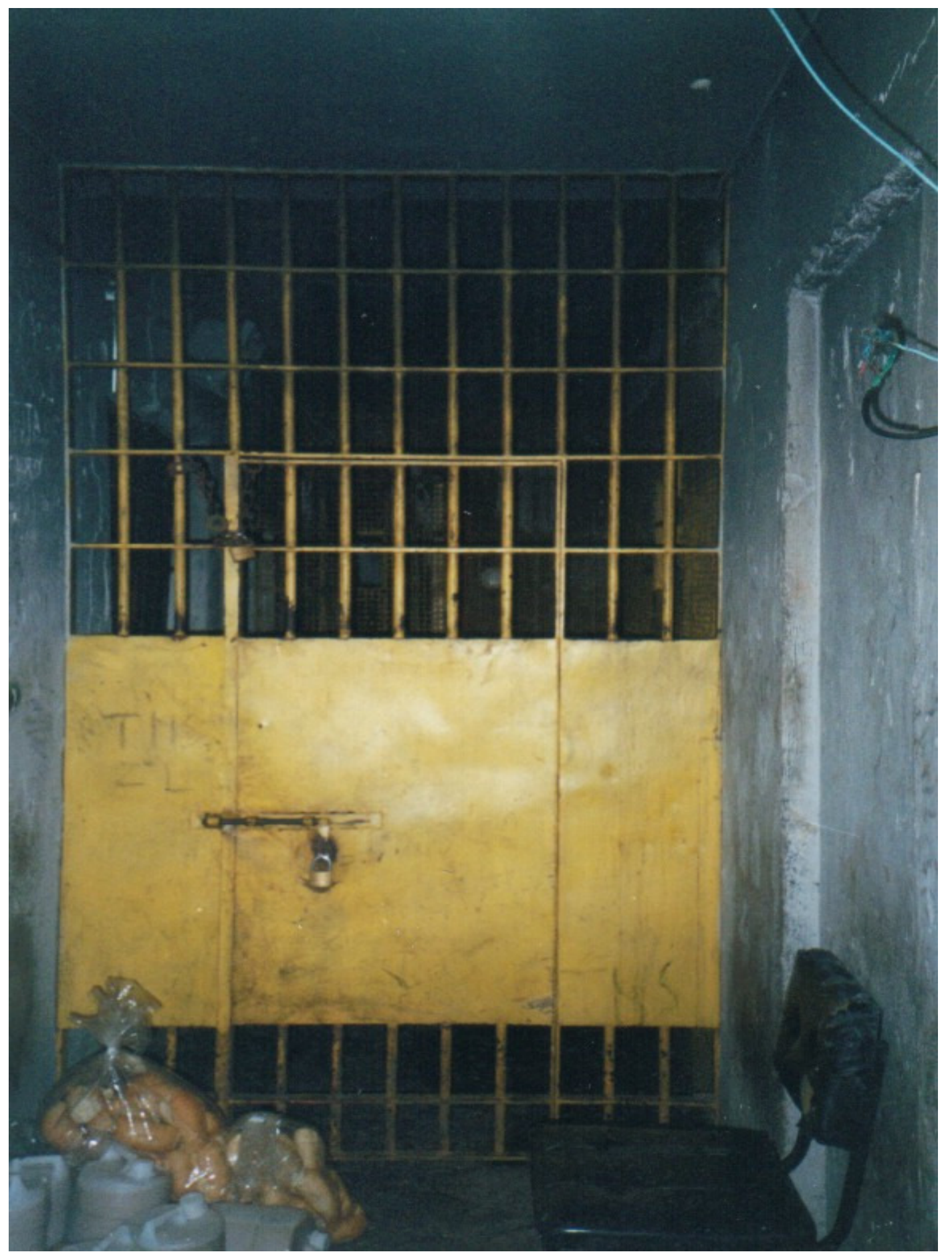




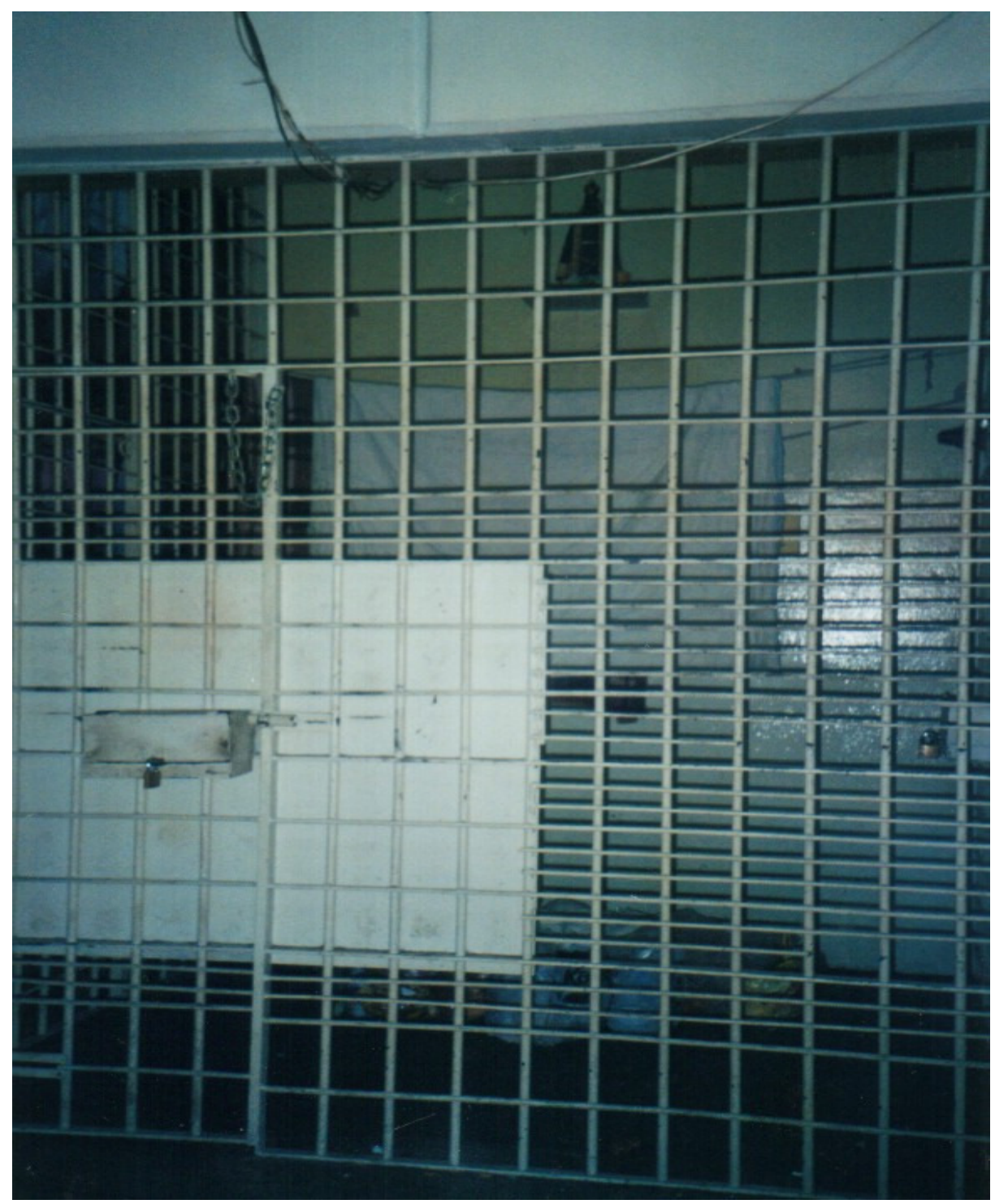

- O café da manhã era servido entre 6 e 7 horas da manhã, era constituído por leite com café e pão. Como havia a necessidade do escarro ser colhido em jejum, procurávamos respeitar este horário.

- O almoço era servido por volta das 11 horas, quando chegavam as "quentinhas" para a maioria dos presos. Aqueles que tinham mais apoio familiar possuíam conta na cantina do DP e recebiam comida diferenciada.

- Durante todas as refeições, o líder local designava um dos detentos para recebê-las. Este detento deveria, excepcionalmente, estar trajado com calça comprida, camisa e chinelo, em sinal de respeito. Normalmente os presos usavam somente uma bermuda e ficavam descalços ou de chinelos porque sapato e tênis não entravam na carceragem, já que poderiam ser usados na escavação de túneis. 
- O líder era sempre o primeiro a ser servido e o que determinava aqueles que “comeriam ou não", e "o quê comeriam”. Além do líder existia o "faxina", que era o preso designado para ser o porta-voz dos outros detentos.

- É necessário esclarecermos que os Policiais Civis não se conformavam com os problemas gerados pela população carcerária nos Distritos Policiais, uma vez que “cuidar de presos" não seria atribuição deles, como não fora no passado. A natural revolta de quem é preso, é direcionada a quem o prendeu e o mantém preso, jamais assumindo que sua condição de recluso foi imposta por decisão do judiciário, sobre um fato criminoso que praticou. Existe, portanto, um antagonismo natural entre policial e recluso. O policial que tem o dever de prender, não pode ao mesmo tempo zelar pelo preso.

- Na realidade, há um grande problema social por trás das grades das carceragens. Excetuando-se os "grandes criminosos", muitos presos haviam cometido pequenos roubos e furtos somente para obterem um teto e alimentação, tal a miséria e desesperança relatada por grande parte deles. Neste contexto, réus primários e provisórios conviviam com ladrões, traficantes e assassinos que possuíam várias passagens pela polícia e já haviam sido julgados e condenados.

- A miséria e desesperança eram tanta, que uma frase de um preso tuberculoso resumiu bem esta realidade. Ao ser notificado de que estava doente, perguntamos se ele recebia visitas regulares para preveni-lo dos riscos da transmissão. A resposta obtida foi a seguinte:

"Tia, eu sou sem terra, sem família, sem amigos ou namorada para me visitarem. Eu não tenho nada. A única coisa que tenho na vida é a tuberculose”.

"É a miséria absoluta, a falta de perspectiva, a total desesperança. A falta de sol, de luz e de ar para respirar; a falta de espaço para andar, comer e dormir, transforma-os em animais enjaulados, que pulando como macacos no alto das grades e de uma cela para outra, e andando sem parar no pátio, como leões acuados, reproduzem um verdadeiro zoológico".

Como não existem estudos referentes à tuberculose na população carcerária dos Distritos Policiais da Cidade de São Paulo, esperamos ter contribuído de alguma maneira para que se divulgue a precariedade da carceragem destes locais, que 
transforma os detentos em importantes reservatórios da doença, como mostram as altas taxas de infecção e de prevalência de tuberculose, encontradas nesta pesquisa. 


\section{8- REFERÊNCIAS*}

01- Adib SM, Al-Takash H, Al-Hajj C. Tuberculosis in Lebanese jails: prevalence and risk factors Eur J Epidemiol 1999; 15: 253-60.

02- Aerts A, Habouzit M, Mschiladze L, Malakmadze N, Sadradze N, Menteshashvili $\mathrm{O}$ et al. Pulmonary tuberculosis in prisons of the ex-USSR state Georgia: results of a nation-wide prevalence survey among sentenced inmates. Int J Tuberc Lung Dis 2000; 4: 1104-10.

03- Andrade L de. Micobactérias atípicas - micobacterioses: etiopatogenia, diagnóstico, tratamento e epidemiologia. J Pneumol 1986; 12: 241-8.

04- Ausina V, Caylà JÁ. Tuberculosis, transmisión reciente y prisiones. Med Clin 2000; 115: 256-7.

05- Barreto AMW, Campos CED. Micobactérias "não tuberculosas" no Brasil. Bol Pneumol Sanit 2000, 8: 23-32.

06- Bastian I, Borgdorff M, Demeulenaere T, Diez M, Goos C, de Haller R et al. Guidelines for the control of tuberculosis in prisions. Geneva: World Health Organization; 2000. ( WHO/CDS/TB/2000.281)

07- Borgdorff MW, Floyd K, Broekmans JF. Interventions to reduce mortality and transmission in low-and middle-income countries. Bull World Health Organ 2002; 80: 217-27.

08- Braun MM, Truman BI, Maguire B. Increasing incidence of tuberculosis in a prision inmate population. JAMA 1989; 261: 393-7.

09- Calero JR. Incremento de la tuberculosis y coinfeccion con el SIDA. An R Acad Nac Med Madr 1995; 12: 21-42.

\footnotetext{
* De acordo com:

Universidade de São Paulo. Faculdade de Saúde Pública. Biblioteca/CIR. Guia de apresentação de Teses. São Paulo; 2001.
} 
10- Carmo MAS, Silva RRF, Hamatsu LS. Avaliação da positividade em culturas para micobactérias, realizadas pelo Método de Ogawa-Kudoh, frente às baciloscopias negativas. IAL Santo André - SP. Laes \& Haes 2002; 3 (137): 126-32.

11- [CDC] Centers for Disease Control and Prevention. Tuberculosis transmission in a State Corretional Institution - California, 1990-1991. JAMA 1993; 269: 200-2.

12- Centro de Vigilância Epidemiológica "Prof. Alexandre Vranjac". Divisão de Tuberculose. Manual de orientação para coleta de amostras de escarro, e outros materiais para baciloscopia e cultura para diagnóstico e controle da tuberculose. São Paulo; 2002.

13- Coelho AGV, Zamarioli LA, Vicente MP, Ferro e Silva RR. Avaliação do método de Ogawa-Kudoh para o isolamento de micobactérias. Rev Inst Adolfo Lutz 1999; 58: 57-61.

14- Coninx R, Maher D, Reyes H, Grzemska M. Tuberculosis in prisons in countries with high prevalence. BMJ 2000; 320: 440-2.

15- Cooke CL. Understanding Incarcerated Populations. AORN J 2002; 75: 56880.

16- Crofton J. Is the increase in tuberculosis epidemic? [Letter] Br J Hosp Med 1994; 52: 419.

17- Cury A. Raio $\mathbf{X}$ do policiamento e da criminalidade na zona oeste de SP. [online] Disponível em <URL:wysiwyg://4/http:www.radiobandeirantes....br/ reporteronline/interna.asp?id_not=3585> [2002 nov 7]

18- Davey S. New global plan to halt TB. Bull World Health Organ 2001; 79: 1172-3.

19- Dolin PJ, Raviglione MC, Kochi A. Global tuberculosis incidence and mortality during 1990-2000. Bull Pan Am Health Organ 1994; 72: 213-20.

20- Festenstein F, Grange JM. Tuberculosis and the acquired immune deficiency syndrome: a review. J Appl Bacteriol 1991; 71: 19-30. 
21- Galesi VMN. Mortalidade por tuberculose no Município de São Paulo, análise de uma década, 1986 a 1995. São Paulo; 1999. [Dissertação de Mestrado - Faculdade de Saúde Pública da USP].

22- García MLG, Gómez JLV, Sancho MCG, Álvarez RAS, Zacarias F, Amor JS. Epidemiology of AIDS and tuberculosis. Bull Pan Am Health Organ 1995; 29: $37-51$.

23- Godfrey-Faussett P, Maher D, Mukadi YD, Nunn P, Perriëns J, Raviglione M. How human immunodeficiency virus voluntary testing can contribute to tuberculosis control. Bull World Health Organ 2002; 80: 939-45.

24- Godoy M. Radiografia do cárcere: faltam espaço e segurança nos DPs. [online] Disponível em <URL:http://www.estado.estadao.com.br/edicao/ encarte/carcere14.html> [2002 nov 5]

25- Hijjar MA. Epidemiologia da tuberculose no Brasil. Inf Epidemiol SUS 1992; p. 53-87.

26- Hijjar MA, Oliveira MJPR, Teixeira GM. A tuberculose no Brasil e no mundo. Bol Pneumol Sanit 2001; 9: 9-16.

27- Holden C. Stalking a killer in Russia’s prisons. Science 1999; 286: 1670.

28- Howard ST, Byrd TF. The rapidly growing mycobacteria: saprophytes and parasites. [Review]. Microbes Infect 2000; 2: 1845-53.

29- Human Rights Watch. O Brasil atrás das grades. [online] Disponível em <URL:http://www.hrw.org/portuguese/reports/presos.htm> [2002 abr 2]

30- IBGE - Instituto Brasileiro de Geografia e Estatística. Censo Demográfico 2000 - Características gerais da população. [online] Disponível em <URL:http://www.ibge.gov.br> [2003 out 6]

31- ILANUD - Instituto Latino Americano para a Prevenção do Delito e Tratamento do Delinqüente. Sistema Penitenciário: mudanças de perfil dos anos 50 aos 90. Rev ILANUD 1997, 6.

32- Kaye D. Global tuberculosis epidemic fuels US trend. (News) Clin Infect Dis 2002; $34: 1$. 
33- Kendig N. Tuberculosis control in prisons. Int J Tuberc Lung Dis 1998; 2 (9 Suppl 1): S57-S63.

34- Kevorkoff G, Micheli Z, Nigro DRA. Tratamiento de micobacteriosis no tuberculosas (MNT) con quinolonas. Rev Fac Cienc Méd Córdoba 1993; 51 : 9-14.

35- Kimerling ME, Kluge H, Vezhnina N, Iacovazzi T, Demeulenaere T, Portaels F et al. Inadequacy of the current WHO re-treatment regimen in a central Siberian prison: treatment failure and MDR-TB. Int J Tuberc Lung Dis 1999; 3: 451-3.

36- Kochi A. The global tuberculosis situation and the new control strategy of the World Health Organization. Bull World Health Organ 2001; 79: 71-5.

37- Levy MH. Tuberculosis control practices in some prison systems of the AsiaPacific Region, 1997. Int J Tuberc Lung Dis 1999; 3: 769-73.

38- Lima Filho MT de. Reação tuberculínica e as reações cruzadas com a vacinação BCG e com infecções por micobactérias não-tuberculosas. J Pneumol 1992; 18: 181-4.

39- Maher D, Grzemska M, Coninx R, Reyes H, Crofton R, Sommaruga C. Guidelines for the control of tuberculosis in prisions. Geneva: World Health Organization; 1998. (WHO/Tb/98.250)

40- Martin V, Gonzalez P. Case finding of pulmonary tuberculosis on admission to a penitenciary centre. Tuberc Lung Dis 1993; 74: 49-53.

41- Martín V, Brugos M, Valcarcel I. Prevalencia de tratamiento de la infección tuberculosa en una Prisión Provincial Rev Esp Salud Pública 2000; 74: 361-6.

42- Ministério da Justiça. Secretaria de Justiça. Departamento Penitenciário Nacional. Censo Penitenciário de 1997. Brasília; 1998.

43- Ministério da Justiça. Departamento Penitenciário Nacional. Sistema prisional: dados consolidados. [online] Disponível em <URL:http://www.mj.gov.br/ depen/institucional.htm> [2003 set 22] 
44- Ministério da Justiça. Secretaria Nacional de Justiça. Departamento Penitenciário Nacional. Sistema de Informações Penitenciárias: informações consolidadas. [online] Disponível em <URL:http://www.mj.gov.br/depen/ sistema_infopen.htm> [2003 set 22]

45- Ministério da Saúde. Fundação Nacional de Saúde. Centro de Referência Professor Hélio Fraga. Manual de bacteriologia da tuberculose. $2^{\mathrm{a}}$ ed. Rio de Janeiro; 1994.

46- Ministério da Saúde. Secretaria Nacional de Programas Especiais de Saúde. Divisão de Pneumologia Sanitária. Campanha Nacional contra a Tuberculose. Controle da tuberculose: uma proposta de integração ensino-serviço. $4^{\text {a }}$ ed. Brasília; 1994.

47- Ministério da Saúde. Fundação Nacional de Saúde. Centro Nacional de Epidemiologia. Coordenação Nacional de Pneumologia Sanitária. Manual de normas para o controle da tuberculose. $4^{\mathrm{a}}$ ed. Brasília; 1995.

48- Ministério da Saúde. Fundação Nacional de Saúde. Centro de Referência Professor Hélio Fraga. Manual de baciloscopia da tuberculose. Rio de Janeiro; 1998.

49- Ministério da Saúde. Fundação Nacional de Saúde. Centro Nacional de Epidemiologia. Centro de Referência Prof. Hélio Fraga. Sociedade Brasileira de Pneumologia e Tisiologia. Controle da tuberculose: uma proposta de integração ensino-serviço. $5^{\text {a }}$ ed. Rio de Janeiro: FUNASA/CRPHF/SBPT; 2002.

50- Ministério da Saúde. Programa Nacional de DST e Aids. Populações. Presídios (População confinada adulta). [online] Disponível em <URL:http://www.aids.gov.br/final/prevencao/presidios.htm> [2003 out 3]

51- Nachega JB, Chaisson RE. Tuberculosis drug resistance: a global threat. Clin Infect Dis 2003; 36 Suppl 1: S24-S30.

52- Niero R. Tuberculose pulmonar em uma prisão: estudo de alguns aspectos epidemiológicos como subsídio para o seu controle. São Paulo; 1981. [Tese de Doutorado - Faculdade de Saúde Pública da USP]. 
53- Nogueira PA. Internações por tuberculose no Estado de São Paulo, 19841997. São Paulo; 2001. [Tese de Livre-Docência - Faculdade de Saúde Pública da USP].

54- Ortegón MM, Rodriguez G, Camargo D, Orozco LC. Micobacterium chelonae y Micobacterium abscessus: patógenos emergentes. Biomedica (Bogotá) 1996; 16: 217-38.

55- Pfyffer GE, Strässle A, van Gorkum T, Portaels F, Rigouts L, Mathieu C et al. Multidrug-resistant tuberculosis in prison inmates, Azerbaijan. Emerg Infect Dis $2001 ; 7: 855-61$.

56- Phillips MS, von Reyn CF. Nosocomial infections due to Nontuberculous Mycobacteria. Clin Infect Dis 2001; 33: 1363-74.

57- Picon PD, Rizzon CFC, Ott WP. Tuberculose: epidemiologia, diagnóstico e tratamento em clínica e saúde pública. Rio de Janeiro: Médico e Científica; 1993.

58- Portaels F, Rigouts L, Bastian I. Addressing multidrug-resistant tuberculosis in penitentiary hospital and in the general population of the former Soviet Union: review article. Int J Tuberc Lung Dis 1999; 3: 582-8.

59- Ramos $\mathrm{CH}$. A vida nos porões da justiça: superlotadas, delegacias, cadeias públicas e penitenciárias transformam-se em centrais do crime, semeando o medo pelo país. [online] Disponível em <URL:http://www.conjunturacriminal.com.br/artigos/kahn102.htm> [2002 nov 7].

60- Raviglione MC, Snider DE, Kochi A. Global epidemiology of tuberculosis: morbidity and mortality of a worldwide epidemic. JAMA 1995; 273: 220-6.

61- Reyes H, Coninx R. Pitfalls of tuberculosis programmes in prisons. BMJ 1997; 315: $1447-50$.

62- Rosemberg J, Tarantino AB, Paula A, Magarão SL. Tuberculose. In: Tarantino, A.B. Doenças pulmonares. $3^{\mathrm{a}}$ ed. Rio de Janeiro: Guanabara Koogan; 1990. p. 233-97. 
63- Rosemberg J. Tuberculose, panorama global: óbices para o seu controle. Fortaleza: Igranol; 1999.

64- Ruffino-Netto A, Souza AMAF. Reforma do setor saúde e controle da tuberculose no Brasil. Inf Epidemiol SUS 1999; 8: 35-51.

65- Ruffino-Netto A. Impacto da reforma do setor saúde sobre os serviços de tuberculose no Brasil. Bol Pneumol Sanit 1999; 7: 7-18.

66- Ruffino-Netto A. Tuberculose: a calamidade negligenciada. Rev Soc Bras Med Trop 2002; 35: 51-8.

67- Ruiz VA, Giménez JL. Micobacterium fortuitum y otras micobacterias no pigmentadas de crecimiento rápido. Control Calidad SEIMC [serial online] 2002; Disponível em <URL:http://www.seimc.org/control/revi_Micobac/mfortu. htm> [2002 abr 2].

68- Salive ME, Vlahov D, Brewer TF. Coinfection with tuberculosis and HIV-1 in male prison inmates. Public Health Rep 1990; 105: 307-10.

69- Sánchez VM, Alvarez-Guisasola F, Caylá JA, Alvarez JL. Predictive factors of Mycobacterium tuberculosis infection and pulmonary tuberculosis in prisoners Int J Epidemiol 1995; 24: 630-6.

70- Secretaria de Estado da Saúde. Coordenação dos Institutos de Pesquisa. Centro de Vigilância Epidemiológica "Prof. Alexandre Vranjac". Divisão de Tuberculose e outras Pneumopatias. Recomendações para o controle da tuberculose nas prisões. São Paulo; 1999.

71- Secretaria de Estado da Saúde. Coordenação dos Institutos de Pesquisa. Centro de Vigilância Epidemiológica "Prof. Alexandre Vranjac". Treinamento Básico de Vigilância Epidemiológica: Módulo específico - Tuberculose. São Paulo; 1999.

72- Secretaria de Estado da Saúde. Coordenação dos Institutos de Pesquisa. Centro de Vigilância Epidemiológica "Prof. Alexandre Vranjac". Divisão de Tuberculose e outras Pneumopatias. Casos novos de tuberculose por forma 
clínica f faixa etária. [online] Disponível em <URL:http://www.cve.saude.sp.gov.br/htm/tb/tb_cn02.htm> [2003 set 25]

73- Smith PG, Moss AR. Epidemiology of tuberculosis In: Bloom BR, editor. Tuberculosis: pathogenesis, protection and control. Washington: ASM Press; 1994. p. 47-57.

74- Snider DE, Hutton MD. Tuberculosis in corretional institutions. JAMA 1989; 261: 436-7.

75- Snider DE, Good RC. Research needs. In: Reichman LB, Hershfield ES, editors. Tuberculosis a comprehensive international approach. New York: Marcel Dekker; 1993. p. 721-31.

76- Stead WW. Undetected tuberculosis in prison. JAMA 1978; 240: 2544-7.

77- Toman K. Tuberculosis case-finding and chemoterapy: questions and answers. Geneva: World Health Organization; 1979.

78- Tulsky JP, White MC, Dawson C, Hoynes TM, Goldenson J, Schecter G. Screening for tuberculosis in jail and clinic follow-up after release Am J Public Health 1998; 88: 223-6.

79- van Crevel R, de Lange WCM, Vanderpuye NA, van Soolingen D, HoogkampKorstanje JAA, van Deuren $M$ et al. The impact of Nontuberculous Mycobacteria on management of presumed pulmonary tuberculosis. Infection 2001; 29: 59-63.

80- Walmsley R. World prison population list. [online]. $2^{\text {nd }}$ ed. Boston; 1999. Avaiable from <URL:http://www.homeoffice.gov.uk/rds/pdfs/r88.pdf> [2003 oct 3]

81- Zacarías F, Gonzáles RS, Cuchí P, Yáñez A, Peruga A, Mazín R et al. HIV/AIDS and its interaction with tuberculosis in Latin America and the Caribbean. Bull Pan Am Health Organ 1994; 28: 312-23. 


\section{ANEXO 1 \\ TERMO DE CONSENTIMENTO ESCLARECIDO}

A pesquisa "Diagnóstico da tuberculose na população carcerária dos Distritos Policiais da Zona Oeste da Cidade de São Paulo" está sendo realizada, porque precisamos conhecer a situação da tuberculose nesta população. Para conseguirmos atingir esse objetivo, precisamos da colaboração do (a) Senhor (a) no sentido de responder a um questionário, fornecer escarro para exames e permitir a aplicação intradérmica do teste tuberculínico.

Consideramos que esta pesquisa não traz riscos maiores para o (a) Senhor (a), além do inconveniente da aplicação de uma injeção na pele. Entretanto, espera-se conseguir um diagnóstico precoce dos doentes com tuberculose, encaminhá-los para tratamento, evitando assim a propagação desta doença no ambiente carcerário, visando a proteção dos detentos sadios e de seus familiares.

Nós, Dr. Péricles Alves Nogueira, Dra. Maria Ivette Carboni Malucelli e a doutoranda Regina Maura Cabral de Melo Abrahão, garantimos que daremos todas as informações que o (a) Senhor (a) necessitar sobre a pesquisa, antes e durante sua realização e que não haverá qualquer prejuízo para o seu cuidado, caso o (a) Senhor (a) se recuse a participar ou desista em qualquer fase da pesquisa.

Asseguramos, também, que as informações registradas serão mantidas em sigilo, sem qualquer identificação do nome dos participantes.

Data.

Assinatura do entrevistador

Nome:
Assinatura do entrevistado Nome:

Telefone de contato: $3066-7730$ 


\section{ANEXO 2 \\ INQUÉRITO INDIVIDUAL}

INQUÉRITO PARA OS DETENTOS DO DISTRITO POLICIAL No

DATA:

No CELA:

No PRONTUÁRIO:

1- NOME:

2- FILIAÇÃO: Pai:

Mãe:

3- IDADE: anos.

4- ESTADO CIVIL:

solteiro

desquitado

TEM FILHOS?

5- COR OU RAÇA:

6- PROCEDÊNCIA: Naturalidade:

$\begin{array}{ll}\text { branca } & \text { preta } \\ \text { amarela } & \text { indígena }\end{array}$

Nacionalidade:

7- NÍVEL DE INSTRUÇÃO:

$$
\begin{aligned}
& \text { sem instrução } \\
& 1^{\circ} \text { grau incompleto } \\
& 2^{\circ} \text { grau incompleto } \\
& \text { superior incompleto }
\end{aligned}
$$

8- PROFISSÃO:

\section{9- JÁ ESTEVE PRESO ANTES?}

Quantas vezes?

$$
€ \operatorname{Sim} \in \text { Não }
$$

Por quanto tempo?

Onde?

10-TEMPO DE PERMANÊNCIA NESTE PRESÍDIO: 
11- JÁ TEVE TUBERCULOSE? €Sim €Não

Recebeu tratamento? Onde?

Por quanto tempo?

12- JÁ TEVE CONTATO COM ALGUMA PESSOA COM TUBERCULOSE? €Sim €Não

Onde?

Com quem?

Por quanto tempo?

13- TEM ALGUM DESTES SINTOMAS?

Tosse com expectoração Há quanto Tempo?

Febre Dor torácica

Perda de peso

Perda de apetite

Hemoptise

14- ESTÁ INFECTADO PELO HIV? €Sim €Não $\quad$ Ignorado

\section{PARA USO DO LABORATÓRIO}

1- PPD

DATA DE APLICAÇÃO:

DATA DA LEITURA:

RESULTADO:

$€$ Negativo (não reator)

$€$ Reator fraco: $\mathrm{mm}$

$€$ Reator forte: $\mathrm{mm}$

\section{2- BACILOSCOPIA}

$€$ Negativa

$€$ Positiva +

$€$ Positiva ++

$€$ Positiva +++

$€$ Não realizada Motivo:

3-CULTURA

$€$ Negativa

$€$ Positiva

$€$ Contaminada

$€$ Não realizada Motivo: 
4- IDENTIFICAÇÃO

5- TESTE DE SENSIBILIDADE 


\section{ANEXO 3 \\ PRÉ CODIFICAÇÃO}

1- No do EPI-INFO:

3- Distrito Policial $n^{\circ}$ :

5- Nome do detento:

6- Nome da mãe:

7- Pai:_ $\quad$ Conhecido $=1 \quad$ Conhecido e falecido $=2 \quad$ Desconhecido $=3$

8- Sexo: $\_$Masculino $=1 \quad$ Feminino $=2$

9- Idade: _ _ anos. (Ignorada $=99)$

10- Estado civil: $\_$Solteiro $=1 \quad$ Casado $=2 \quad$ Separado $=3 \quad$ Desquitado $=4$ Divorciado $=5 \quad$ Viúvo $=6 \quad$ Amasiado $=7 \quad$ Ignorado $=9$

11- Tem filhos? _ $\quad$ Sim $=1 \quad$ Não $=2 \quad$ Ignorado $=9$

Obs: Se a resposta for sim, passar para a questão 12. Se não, para a 13.
12- Quantos?
1 filho $=1$
2 filhos $=2$
3 filhos $=3$
4 filhos $=4$ 5 filhos $=5$
Mais que 5 filhos $=6$

13- Cor ou raça: _

Branca $=1 \quad$ Preta $=2 \quad$ Parda $=3 \quad$ Amarela $=4$

Indígena $=5 \quad$ Outra $=6 \quad$ Ignorada $=9($ IBGE-2000 $)$

14- Nacionalidade:

Brasileiro nato $=1$

Brasileiro naturalizado $=2$
Estrangeiro $=3 \quad$ Ignorada $=9 \quad($ IBGE - Censo 2000 - www.ibge.gov.br)

15- Cidade onde nasceu: _ Capital de Estados Brasileiro $=1 \quad$ Cidade grande $=2$ Cidade de porte médio $=3 \quad$ Cidade pequena $=4$

Sem informação $=9$

Obs: Cidade grande $=$ acima de 200 mil habitantes.

Cidade de porte médio $=$ de 50 a 200 mil habitantes.

Cidade pequena $=$ até 50 mil habitantes.

(IBGE-2000 - www.ibge.gov.br - Cidades@ - O Brasil Município por Município) 
16 - Estado onde nasceu: _ _ （sigla do Estado - IBGE-2000 - www.ibge.gov.br Cidades@-O Brasil Município por Município)

17- Nível de instrução:_ $\quad$ Sem instrução $=1$

$1^{\circ}$ grau completo $=3$

$2^{\circ}$ grau completo $=5$

Superior completo $=7$ $1^{\circ}$ grau incompleto $=2$

$2^{\circ}$ grau incompleto $=4$

Superior incompleto $=6$

Ignorado $=9$

18- Profissão: (30)

19- Estava empregado no momento da prisão?_Sim $=1 \quad$ Não $=2 \quad$ Ignorado $=9$

Obs: Se a resposta for sim, passar para a questão 20. Se não, para a 21.

20- Qual era sua renda na época?_

$$
\begin{aligned}
& <\text { que } 1 \mathrm{sm}=1 \\
& >2 \text { a } 5 \mathrm{sm}=3 \\
& >\text { que } 10 \mathrm{sm}=5
\end{aligned}
$$

De 1 a $2 \mathrm{sm}=2$

$>5$ a $10 \mathrm{sm}=4$

Ignorada $=9$

Obs: Salário mínimo da época da pesquisa:

- $1^{\circ}$ de maio de $1999=\mathrm{R} \$ 136,00$.

- 03 de abril de $2000=\mathrm{R} \$ 151,00$.

- $1^{\circ}$ de abril de $2001=\mathrm{R} \$ 180,00$.

21- Endereço: (Código da Secretaria de Estado da Saúde com 5 dígitos)
22- Uso de álcool: _
$\operatorname{Sim}=1$
Não $=2$
Ignorado $=9$
23- Uso de maconha:
$\operatorname{Sim}=1$
Não $=2$
Ignorado $=9$
24- Uso de crack: _
$\operatorname{Sim}=1$
Não $=2$
Ignorado $=9$
25- Uso de cocaína:
$\operatorname{Sim}=1$
Não $=2$
Ignorado $=9$

26- Tempo de permanência neste Distrito Policial:

dias $\quad(1$ ano=365 dias;

1 mês=30 dias; 1 semana $=7$ dias)

27- Delito atual 1: $\_$- $\quad$ Homicídio $=01 \quad$ Tentativa de homicídio $=02$

Latrocínio $=03 \quad$ Roubo $=04 \quad$ Tentativa de roubo $=05 \quad$ Furto $=06$

Tentativa de furto $=07 \quad$ Porte ilegal de arma $=08 \quad$ Tráfico de drogas $=09$

Porte de entorpecente $=10 \quad$ Seqüestro e cárcere privado $=11 \quad$ Estupro $=12$

Tentativa de estupro $=13 \quad$ Atentado violento ao pudor $=14 \quad$ Estelionato $=15$

Formação de quadrilha/bando $=16$ Receptação dolosa $=17 \quad$ Corrupção ativa $=18$

Lesão corporal dolosa $=19$ Corrupção de menores art. $1^{\circ}=20 \quad$ Corrupção de menores art. $218=21 \quad$ Ameaça $=22 \quad$ Extorsão $=23 \quad$ Extorsão mediante seqüestro $=24$ Falsificação de documento público $=25 \quad$ Falsidade ideológica $=26$ 
Uso de documento falso $=27 \quad$ Resistência à prisão $=28 \quad$ Desacato $=29$

Outros $=30 \quad$ Ignorado $=99$

28- Delito atual 2:

29- Delito atual 3: - -

30- Delito atual 4: _-

31- Delito atual 5:
$($ Idem + Não cometeu outro delito atual $=31)$

$($ Idem + Não cometeu outro delito atual $=31)$

$($ Idem + Não cometeu outro delito atual $=31)$

$($ Idem + Não cometeu outro delito atual $=31)$

32- Se estava cumprindo pena no Distrito Policial: _ $\quad$ Sim $=1 \quad$ Não $=2$ Ignorado $=9$

Obs: Já foi julgado e condenado e permanece no Distrito.

33- Já esteve preso antes? _ $\quad$ Sim $=1 \quad$ Não $=2 \quad$ Ignorado $=9$

Obs: Se a resposta for sim, passar para as questões 34 a 42 . Se não, para a 43.

34- Quantas vezes?__ $\quad 1 \mathrm{vez}=1 \quad 2$ vezes $=2 \quad 3$ vezes $=3 \quad 4$ vezes $=4$

$$
5 \text { vezes }=5 \quad \text { Mais que } 5 \text { vezes }=6 \quad \text { Ignorado }=9
$$

35- Por quanto tempo? dias $(1$ ano $=365$ dias; 1 mês $=30$ dias; 1 semana $=7$ dias $)$

36- Local 1: _ Febem $=1$ Outros Distritos Policiais $=2 \quad$ Casa de Detenção $=3$ Penitenciária do Estado $=4 \quad \mathrm{CDP} .=5 \quad$ Interior de São Paulo $=6$ Outros Estados $=7 \quad$ Ignorado $=9$

37- Local 2: _ $\quad$ (Idem + Não ficou em outro local = 8)

38- Local 3: _ _ $\quad$ (Idem + Não ficou em outro local = 8)

39- Local 4: _ _ $\quad$ (Idem + Não ficou em outro local = 8)

40- Delito anterior 1: _ _ _ (Idem a questão 27)

41- Delito anterior 2: _ _ $\quad$ (Idem + Não cometeu outro delito anterior $=31)$

42- Delito anterior 3: _ _ $\quad$ (Idem + Não cometeu outro delito anterior = 31)

43- Já teve tuberculose? _ $\quad$ Sim $=1 \quad$ Não $=2 \quad$ Ignorado $=9$

Obs: se a resposta for sim, passar para as questões 44 a 46. Se não, para a 47.
44- Recebeu tratamento? _
$\operatorname{Sim}=1$
Não $=2$
Ignorado $=9$
45- Onde? _
Na residência $=1 \quad$ Centro de Saúde $=2$
Hospital $=3$
Presídio $=4$
Outros $=5$
Ignorado $=9$
46- Por quanto tempo?

$$
\begin{array}{lrr}
\text { Menos de } 1 \text { mês }=1 & 1 \text { mês }=2 & 2 \text { meses }=3 \\
3 \text { meses }=4 & 4 \text { meses }=5 & 5 \text { meses }=6 \\
6 \text { meses }=7 & \text { Mais que } 6 \text { meses }=8 & \text { Ignorado }=9
\end{array}
$$$$
2 \text { meses }=3
$$$$
6 \text { meses }=7 \text { Mais que } 6 \text { meses }=8
$$ 
47- Já teve contato com alguma pessoa com tuberculose?

$$
\begin{aligned}
& \operatorname{Sim}=1 \quad \text { Não }=2 \\
& \text { Ignorado }=9
\end{aligned}
$$

\begin{tabular}{|c|c|c|c|c|}
\hline \multirow{2}{*}{ 48- Onde? - } & \multicolumn{2}{|c|}{ Na residência = 1} & No trabalho $=2$ & \multirow[t]{2}{*}{ No presídio $=3$} \\
\hline & Outros $=4$ & & Ignorado $=9$ & \\
\hline \multirow[t]{2}{*}{ 49- Com quem? _- } & Familiares $=1$ & & Vizinhos $=2$ & Colegas de trabalho $=3$ \\
\hline & Detentos $=4$ & & Outros $=5$ & Ignorado $=9$ \\
\hline \multirow{4}{*}{\multicolumn{2}{|c|}{ 50- Por quanto tempo? }} & $<\mathrm{qu}$ & 1 mês $=1$ & De 1 a 2 meses $=2$ \\
\hline & & $>q u$ & 2 a 4 meses $=3$ & $>$ que 4 a 6 meses $=4$ \\
\hline & & $>c$ & 6 a 12 meses $=5$ & $>$ que 12 meses $=6$ \\
\hline & & Igno & $o=9$ & \\
\hline
\end{tabular}

Obs: Se a resposta for sim, passar para as questões 48 a 50. Se não, para a 51 .

51- Sintoma 1: _

$$
\begin{array}{lrr}
\text { Sem sintomas }=1 & \multicolumn{2}{c}{\text { Tosse com expectoração }=2} \\
\text { Febre }=3 & \text { Dor torácica }=4 & \text { Perda de peso }=5 \\
\text { Perda de apetite }=6 & \text { Hemoptise }=7 & \text { Outros }=8 \\
\text { ignorado }=9 & &
\end{array}
$$

52- Sintoma 2: _ $\quad$ (Idem + Não tem outro sintoma $=0)$

53- Sintoma 3: $\quad$ _ $\quad$ (Idem + Não tem outro sintoma $=0)$

54- Sintoma 4: _ $\quad$ (Idem + Não tem outro sintoma $=0)$

55- Sintoma 5: _ $\quad$ (Idem + Não tem outro sintoma $=0)$

56- Tempo de sintomas: ${ }_{-}{ }_{-}$dias $\quad$ Não tem sintomas $=000$ Ignorado $=999$

57-HIV: _ $\quad$ Sim $=1 \quad$ Não $=2 \quad$ Ignorado $=9$

58- Leitura do PPD: $\_\quad$ Não reator $=1 \quad$ Reator fraco $=2 \quad$ Reator forte $=3$

Não fez a leitura $=4 \quad$ Não realizado $=9$

Obs: se for reator forte, passar para a questão 59. Se não, para a 60.

59- Reator forte com flictena ou necrose? $-\quad$ Sim $=1 \quad$ Não $=2$

60- Número de amostras de escarro colhidas: _ 1 amostra $=1 \quad 2$ amostras $=2$

Não colheu $=9$

Obs: Se não colheu, passar para a questão 61. Se colheu, para a 62.

61- Motivo para não colheita da amostra: _ $\quad$ Não conseguiu $=1 \quad$ Recusou $=2$

Havia feito em outro DP $=3 \quad$ Alvará de soltura $=4$

Foi transferido $=5 \quad$ Estava hospitalizado $=6$

Estava no fórum $=7 \quad$ Outro $=8 \quad$ Ignorado $=9$ 
62- Baciloscopia: _

$$
\begin{array}{llr}
\text { Negativa }=1 & \text { Positiva }+=2 & \text { Positiva }++=3 \\
\text { Positiva }+++=4 & \multicolumn{2}{c}{\text { Não realizada }=5} \\
\text { Negativa }=1 & \text { Positiva }+=2 & \text { Positiva }++=3 \\
\text { Positiva }+++=4 & \text { Contaminada }=5 & \text { Não realizada }=6
\end{array}
$$

63- Cultura:

Obs: Se positiva, passar para as questões 64 e 65 .

64- Identificação:_ $M$. tuberculosis $=1 \quad$ M. fortuitum $=2 \quad$ M. chelonae $=3$ Complexo $M$. fortuitum $M$. chelonae $=4 \quad M$. nonchromogenicum $=5$ Micobactéria de crescimento rápido acromógena $=6 \quad$ Outras $=9$ 65- Teste de sensibilidade: _ $\quad$ Sensível $=1 \quad$ Resistente à INH e RMP $=2$ Resistente à INH, RMP e PZA = 3 